\title{
Ireland: Fiscal Transparency Assessment
}

This pilot Fiscal Transparency Assessment for Ireland was prepared by a staff team of the International Monetary Fund as background documentation for the periodic consultation with the member country. It is based on the information available at the time it was completed in July, 2013. The views expressed in this document are those of the staff team and do not necessarily reflect the views of the government of Ireland or the Executive Board of the IMF.

The policy of publication of staff reports and other documents by the IMF allows for the deletion of market-sensitive information.

\author{
Copies of this report are available to the public from \\ International Monetary Fund • Publication Services \\ $70019^{\text {th }}$ Street, N.W. • Washington, D.C. 20431 \\ Telephone: (202) 623-7430 • Telefax: (202) 623-7201 \\ E-mail: publications@imf.org Internet: http://www.imf.org
}

\section{International Monetary Fund Washington, D.C.}




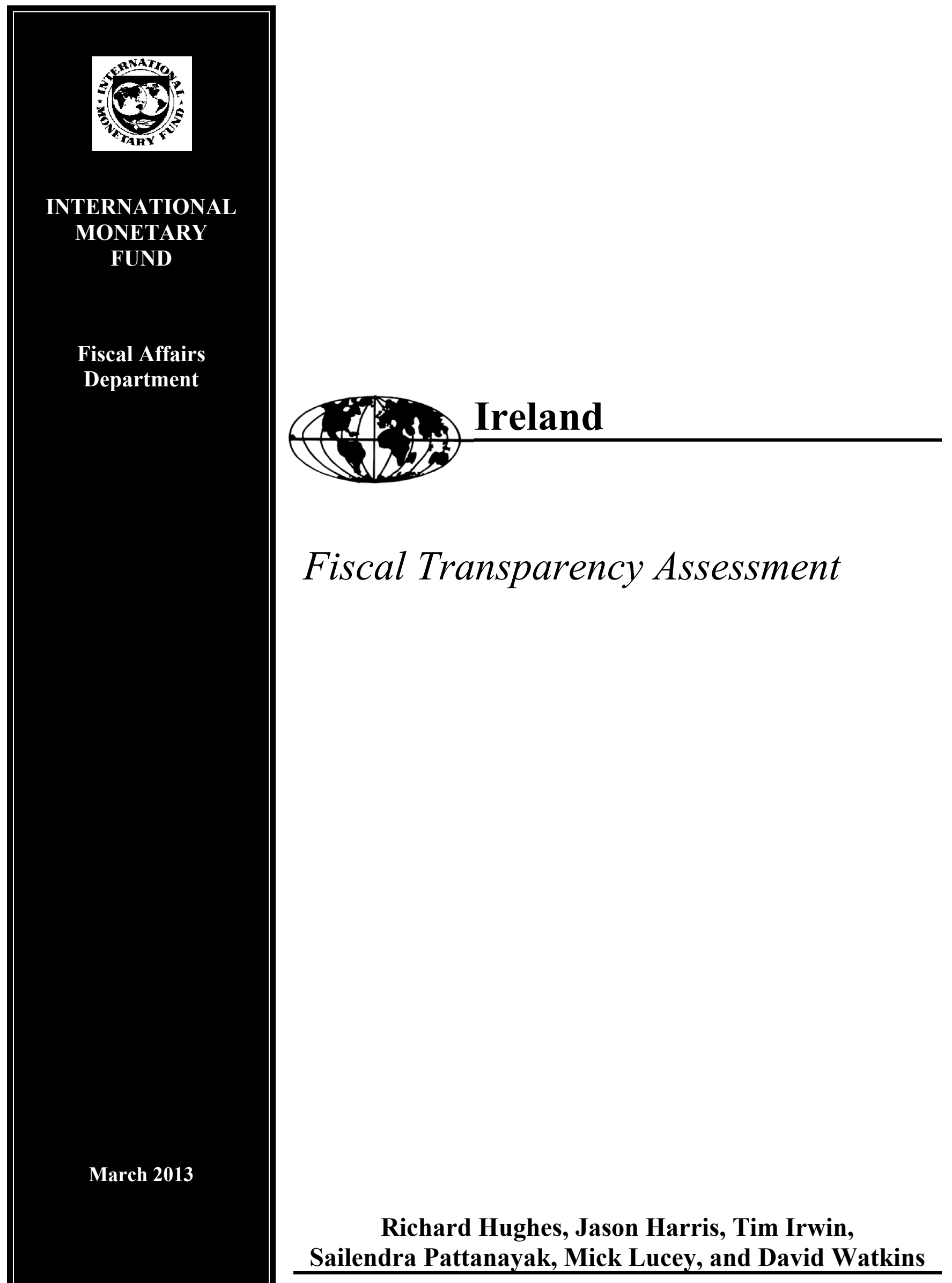


CONTENTS

PAGE

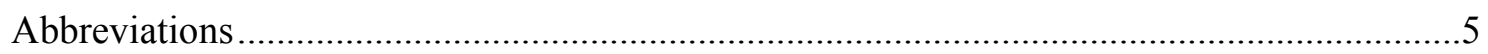

Preface

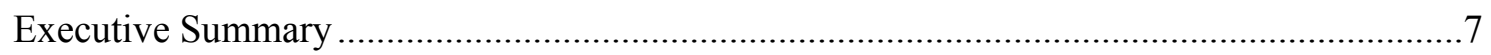

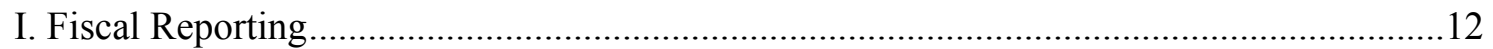

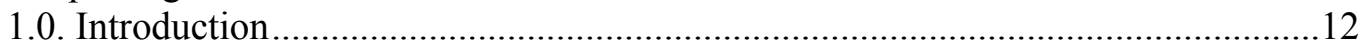

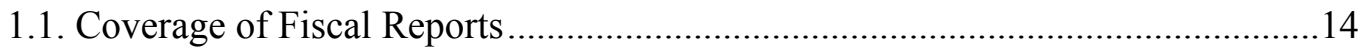

1.2. Frequency and Timeliness of Fiscal Reporting ...............................................23

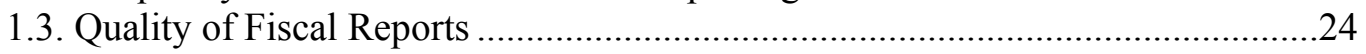

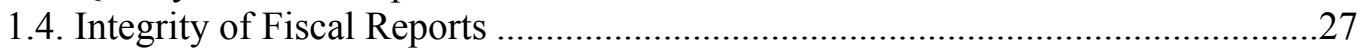

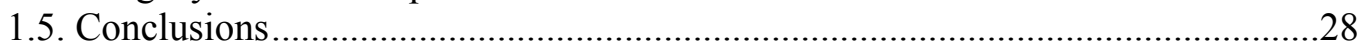

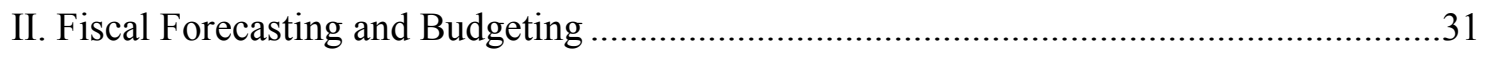

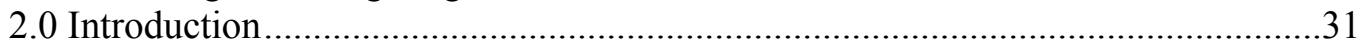

2.1 Comprehensiveness of Budget Documentation ...................................................32

2.2. Timeliness of Budget Submission and Approval..................................................

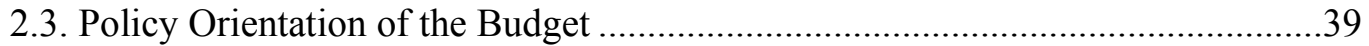

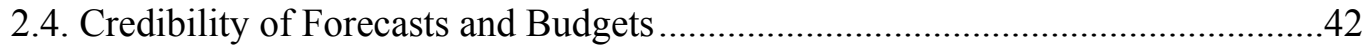

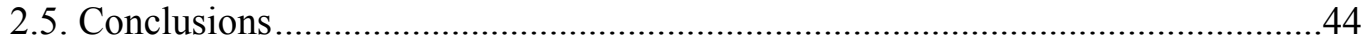

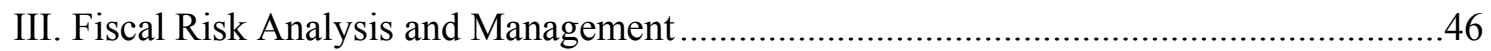

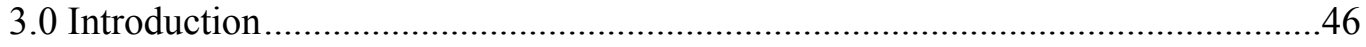

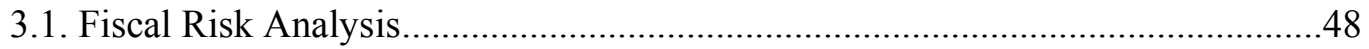

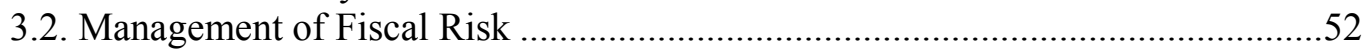

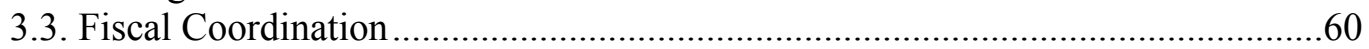

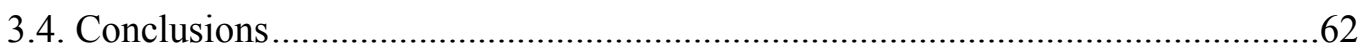

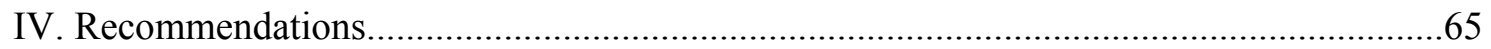

1. Expand the Institutional Coverage of Fiscal Reports .........................................66

2. Recognize a Wider Range of Assets and Liabilities ...........................................67

3. Incorporate Associated Accrued Revenues and Expenses...................................67

4. Modernize the Budget and Accounting Classification ...........................................68

5. Bring Forward the Timetable for Budgeting, Accounting, and Audit .....................69

6. Prepare Long-term Fiscal Projections............................................................... 70

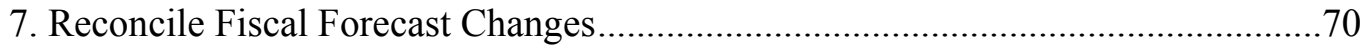

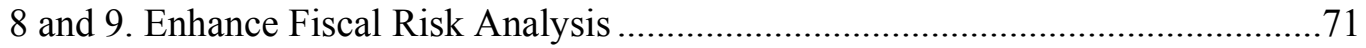

10. Harmonize Financial Reporting Standards and Practices .....................................72

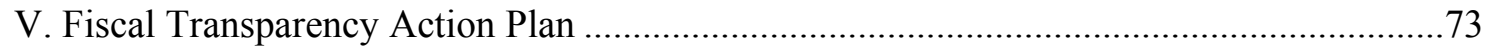




\section{TABLES}

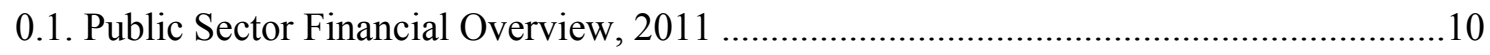

0.2. Summary Assessment against Fiscal Transparency Code ...........................................11

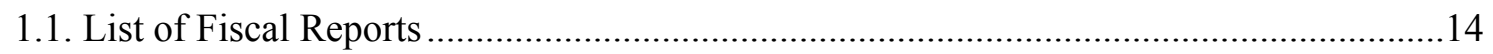

1.2. Public Sector: Institutional Composition and Finances (2011) .....................................15

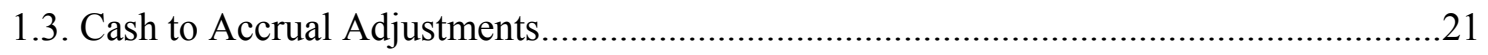

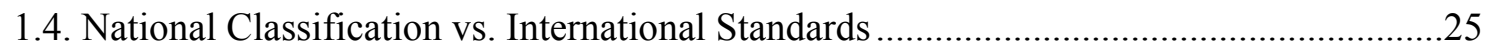

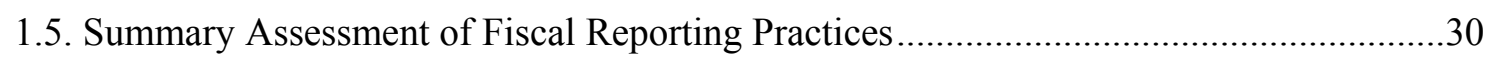

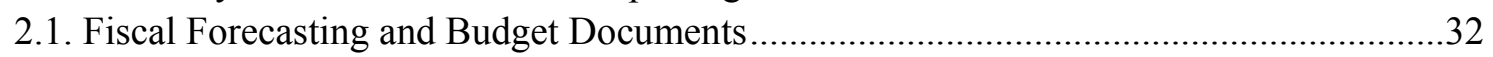

2.2. Summary Assessment of Ireland's Fiscal Forecasting and Budgeting ............................45

3.1. Indebtedness and Leverage in Selected Advanced Economies, 2012 .............................46

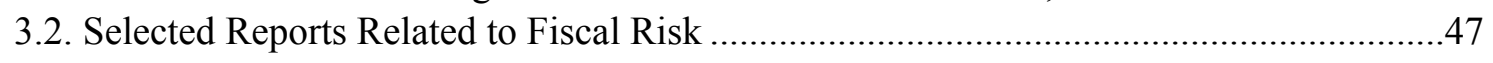

3.3. Selected Contingent Liabilities of General Government .............................................50

3.4. Reconciling Revenue and Expenditure between Exchequer and the Government...........52

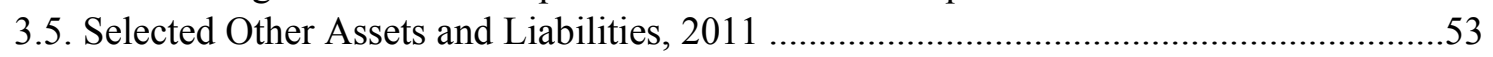

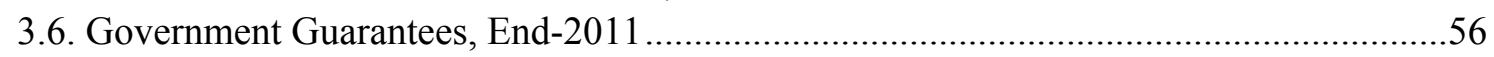

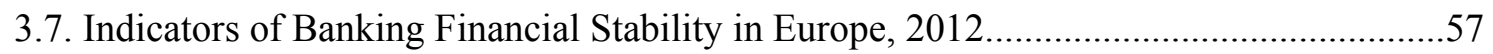

3.8. Nominal and Market Values of Derivatives, 2010-12 ...............................................59

3.9. Summary Assessment of Fiscal Risk Analysis and Management Practices....................64

\section{Figures}

1.1. Coverage of Public Sector Institutions in Fiscal Reports .............................................17

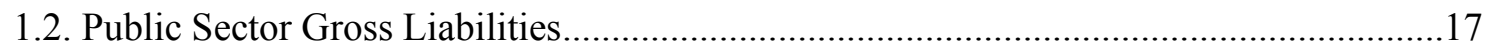

1.3. Public Sector Balance Sheet and Coverage in Fiscal Reports .........................................18

1.4. Public Sector Net Worth in Selected Countries ................................................................19

1.5. Gross Public Sector Pension Liabilities in Selected Countries.......................................19

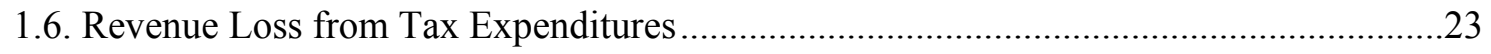

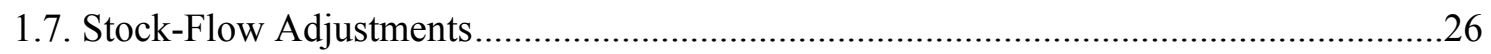

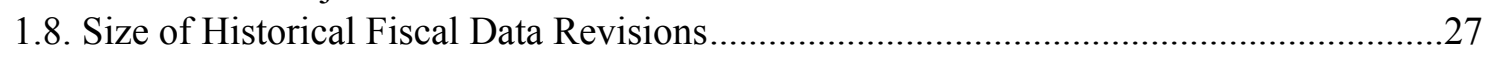

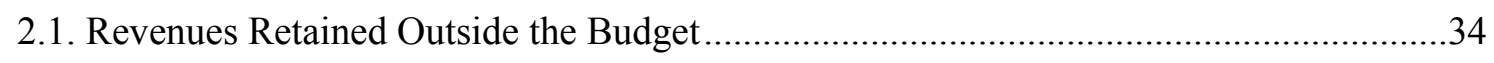

2.2. Average Real GDP Absolute Forecast Errors, 1998-2007 ...........................................35

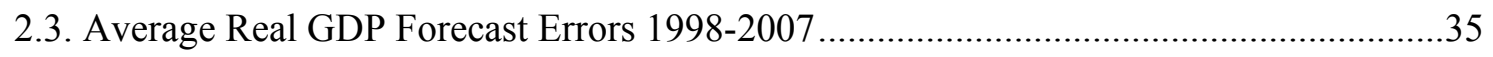

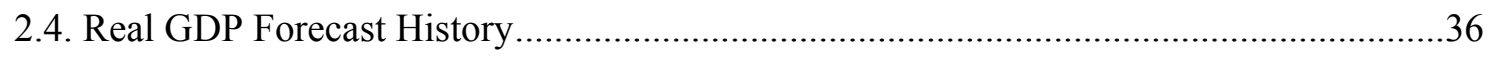

2.5. Average Budget Balance Forecasting Error 1998-2007 ...............................................37

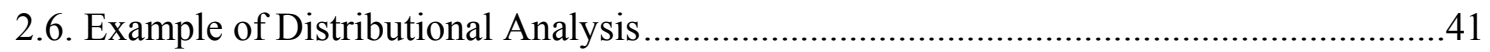

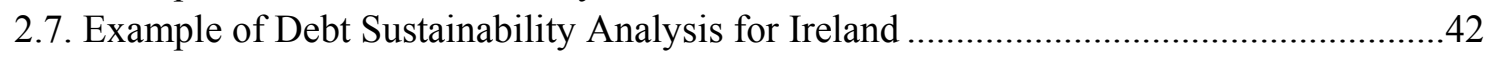

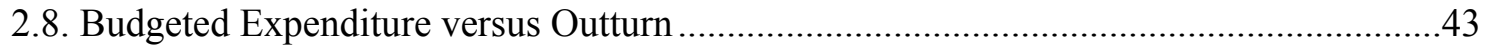

3.1. Indicators of Macrofiscal Risk in the Euro Area, 1999-2008 .......................................48

3.2. IFAC's Estimate of Uncertainty Surrounding Future Deficits ......................................49

3.3. General Government Financial Assets and Liabilities, 2002-12 ...................................53

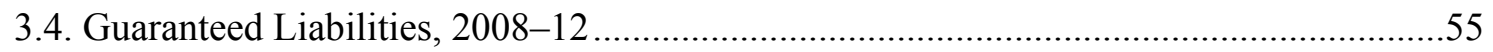

3.5. Government Guarantees Related to Financial Crisis, Euro Area, 2011 ...........................55

3.6. Estimated Size of PPPs in Ireland, Portugal, and UK ................................................58 
3.7. Net Value of Derivatives of General Government, 2002-12 (Q3) .................................59

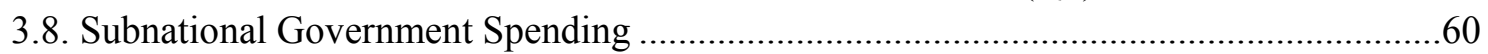

3.9. Local Government Debt and Debt Service to Revenue Ratios......................................61

3.10. Liabilities of Largest Public Corporations, 2011 ..........................................................62

APPENDICES

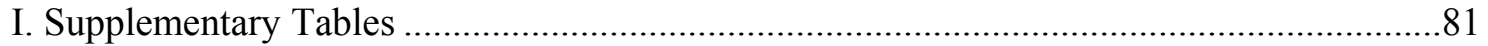

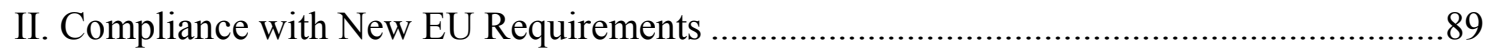

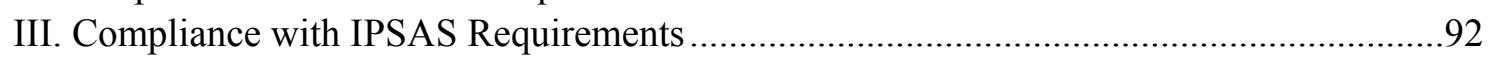

IV. Possible Outline of a Statement of Fiscal Risks .................................................................95

\section{APPENDIX TABLES}

1A. Consolidated General Government Gross Revenue and Expenditure (By Sector)..........82

1B. Consolidated Central Government Gross Revenues and Expenditures (By Institution) .83

1C. Consolidated Central Government Financial Statements..............................................84

1D. Overview of General Government Revenue, Expenditure and Balance by Subsector ....85

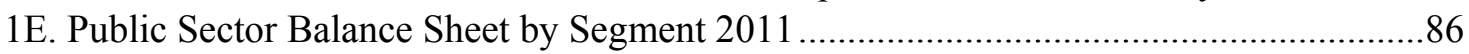

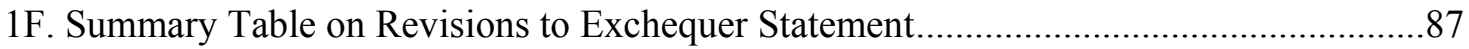

1G. Mapping of Exchequer Statement to ESA 95 Classification .........................................88 


\section{ABbreviations}

\begin{tabular}{|c|c|}
\hline C\&AG & Comptroller and Auditor General \\
\hline $\mathrm{CBI}$ & Central Bank of Ireland \\
\hline $\mathrm{CFO}$ & Chief Financial Officer \\
\hline CIE & Córas Iompair Éireann (Irish Transport Authority) \\
\hline CRE & Comprehensive Review of Expenditure \\
\hline COFOG & Classification of Functions of Government \\
\hline $\mathrm{CSO}$ & The Central Statistical Office \\
\hline $\mathrm{EC}$ & European Commission \\
\hline ESA95 & European System of National and Regional Accounts 95 \\
\hline DGA & Director of Government Accounting \\
\hline DoF & Department of Finance \\
\hline EDP & Excessive Deficit Procedure \\
\hline FRL & Fiscal Responsibility Law \\
\hline GFSM & Government Finance Statistics Manual \\
\hline IBRC & Irish Bank Resolution Corporation \\
\hline IFAC & Irish Fiscal Advisory Council \\
\hline IFRS & International Financial Reporting Standards \\
\hline IPSAS & International Public Sector Accounting Standards \\
\hline ISSAI & International Standards of Supreme Audit Institutions \\
\hline MTEF & Medium-term Expenditure Framework \\
\hline NAMA & National Asset Management Agency \\
\hline NewERA & New Economy and Recovery Authority \\
\hline NTF & National Training Fund \\
\hline NTMA & National Treasury Management Agency \\
\hline NPRF & National Pension Reserve Fund \\
\hline SDDS & Special Data Dissemination Standard \\
\hline SIF & Social Insurance Fund \\
\hline SPU & Stability Program Update \\
\hline
\end{tabular}




\section{PREFACE}

In response to a request from the Secretaries General of the Irish Departments of Finance and Public Expenditure and Reform, a mission from the Fiscal Affairs Department (FAD) of the International Monetary Fund (IMF) visited Dublin, Ireland during the period March 12 to 25, 2013 to conduct a pilot Fiscal Transparency Assessment. The mission was led by Richard Hughes and included Jason Harris, Tim Irwin, and Sailendra Pattanayak (all FAD staff) and Mick Lucey and David Watkins (both FAD experts).

The objective of the Fiscal Transparency Assessment was to evaluate Ireland's fiscal reporting, forecasting and budgeting, and fiscal risks analysis and management practices against the standards set by the IMF's newly revised Fiscal Transparency Code. ${ }^{1}$ The mission was organized around a series of discussions with representatives from key stakeholder organizations in the Irish administration including: the Department of Finance; Department of Public Expenditure and Reform; Department for Environment, Community, and Local Government; Central Statistics Office; Office of the Revenue Commissioners; Central Bank of Ireland; National Treasury Management Agency; Comptroller and Auditor General's Office; Irish Fiscal Advisory Council; and the Oireachtas (Parliament).

This report is based on the information available at the time it was completed in March 2013. The findings, recommendations, and action plan set out in this report represent the views and non-binding advice of the IMF mission team and do not necessarily reflect the views of or a commitment by the government of Ireland. Unless otherwise specified, the data included in the text, figures, and tables in the report are estimates of the IMF mission team and not official estimates of the government of Ireland.

The mission would like to thank the Irish authorities for their excellent collaboration in the conduct of this pilot assessment and for the frank and open exchanges of views on all matters discussed. Particular thanks go to Garrett O'Neill and Fiachra Quinlan for supporting the work of the mission before, during, and after its time in Dublin.

\footnotetext{
${ }^{1}$ The assessment of Ireland's fiscal transparency practices as either Advanced, Good, Basic, or Not Met refer to the principles and practices included in the IMF's Fiscal Transparency Code which can be found at www.imf.org/fiscal transparency.
} 


\section{EXECUTIVE SUMMARY}

For decades Ireland maintained the traditional system of government budgeting and accounting it inherited from the UK at independence in 1922. Until the 1990s, fiscal reports confined themselves to budgetary central government (the Exchequer), covered only cash transactions and debt, and did not follow an internationally recognized classification system. Ireland's budget documentation focused exclusively on the year ahead, excluded own-source revenues of departments, and provided little information about the outputs or outcomes to be delivered with public resources. Fiscal forecasts provided point estimates with little discussion of alternative scenarios or fiscal risks.

Following a series of substantial, if somewhat piecemeal, improvements, Ireland is now approaching best practice in fiscal reporting and forecasting and meets the basic requirements for fiscal risk disclosure under the IMF's Fiscal Transparency Code (Table 0.2). Since the early 1990s, European integration and the recent financial crisis have been catalysts for significant improvements in fiscal transparency in Ireland. The Maastricht Treaty reporting requirements obliged the government to begin producing fiscal statistics that cover the general government, capture some accrual flows, and are classified according to the European System of Accounts 1995 (ESA95). The pace of transparency-related reforms quickened in the wake of the 2008 crisis with the passage of a new Fiscal Responsibility Law (FRL), establishment of the Irish Fiscal Advisory Council (IFAC), introduction of a medium-term expenditure framework (MTEF), and regular reporting of the government's financial sector interventions in the form of capital injections, guarantees, and other exposures.

Today, fiscal reporting is relatively comprehensive, frequent, and reliable but also quite fragmented. Fiscal statistics cover all general government entities and 81 percent of public sector expenditure but still exclude public corporations with net expenditure of 12 percent and assets and liabilities of 204 percent of GDP. ${ }^{2}$ Fiscal statistics include a balance sheet of the general government's 39 percent of GDP in financial assets and 106 percent of GDP in liabilities. Information about the general government's 74 percent of GDP in fixed assets, 75 percent of GDP in liabilities from public service pensions and PPPs, and 1.1 percent of GDP in associated accrual flows is available but scattered across multiple documents, produced by multiple parties, on a range of different accounting bases, with varying frequencies. Cash-based budget execution reports are published monthly but cover only the Exchequer and use a traditional classification which does not correspond to the government's new ESA95-based general government fiscal rules. Detailed ESA95-based fiscal statistics are only published annually, although general government deficit and debt figures are available each quarter. The government prepares two sets of annual accounts which are audited and published within nine months of year-end, but neither provides a comprehensive overview of the central government finances or follows international accounting standards though they do conform with domestic legal requirements. Despite the

\footnotetext{
${ }^{2}$ All percent of GDP figures in the Executive Summary are for 2011 unless otherwise specified.
} 
fragmentation and different basis of the source data, Ireland's general government fiscal data are generally reliable. The Central Statistical Office (CSO) and Comptroller and Auditor General (C\&AG) are independent and follow relevant EU and international standards. Summary fiscal data are subject to two of three key internal consistency checks and revisions to historical data are disclosed and relatively modest on average.

Fiscal forecasts and budgets provide a credible, detailed, and policy-oriented overview of fiscal prospects, but could provide a more comprehensive account of extrabudgetary activity, changes between forecasts, and longer-term trends. The government's fiscal rules are set out in its 2012 FRL which, together with European rules and the new MTEF, determine the fiscal targets and expenditure limits for the budget year and medium term. Fiscal projections are published twice a year, based on credible and detailed macroeconomic forecasts, and independently evaluated by the Irish Fiscal Advisory Council (IFAC). The budget document distinguishes the impact of current and new policies, provides extensive information about their distributional impact, and states the objectives to be achieved and outputs to be delivered under each expenditure program. However, budget documents do not include information about financial plans of central government entities outside the Exchequer whose self-funded expenditures amount to 4.3 percent of GDP. There is also no comprehensive reconciliation of changes to the fiscal forecast between fiscal strategies and budgets. Finally, the government does not regularly publish comprehensive long-term fiscal projections, despite age-related expenditures pressures of 7.4 percent of GDP by 2050 .

Fiscal risks are relatively large in Ireland and their disclosure and management are diffuse. Budget documentation provides analysis of the sensitivity of key fiscal aggregates and IFAC produces probabilistic fiscal scenarios based on historical forecast errors. However, reporting on Ireland's 137 percent of GDP in quantified contingent liabilities and other specific fiscal risks is scattered across many documents published by many different agencies. Government guarantees worth 77 percent of GDP have been extended at the discretion of the Minister of Finance (MoF) in accordance with legislation and are disclosed in the annual Finance Accounts. Central government borrowing is controlled by the MoF and managed by the National Treasury Management Agency (NTMA) which publishes information on each of the various portfolios of assets and liabilities (including derivatives) for which it is responsible, but not a consolidated report on the whole portfolio and its strategy for its management. The central government's nominal commitments under PPPs are disclosed in the C\&AG's 2011 report on the government accounts, in the accounts of relevant Departments or State agencies, and on the DPER website, but not projected payments by year over the remaining lives of the contracts. Government support to the financial sector is reported to Eurostat and discussed in the C\&AG's report, but the government does not provide its own assessment of potential fiscal risks created by the financial sector. Borrowing by local governments is tightly controlled and their total debt contributes less than 1 percent to general government liabilities. While government transfers to and dividends from public corporations are disclosed in the budget, there is no comprehensive combined reporting on a sector whose liabilities accounts for 53 percent of total public liabilities. 
The Irish government has ambitious plans to improve further the timeliness, quality, and comprehensiveness of its budgets, statistics, and accounts. The government plans to begin publishing quarterly general government fiscal statistics and bring forward the submission of the budget by two months to mid-October to meet the requirements of the EU Six Pack and Two Pack of fiscal governance reforms. The Coalition Government's Fiveyear Program for Government commits all public sector bodies to publish balance sheets and move from cash to accrual accounting. The government has also established a separate entity, NewERA, to provide financial and commercial advice from a shareholder perspective on its interests in five major public corporations.

Ireland has the capacity and information to bring its fiscal transparency practices into line with international best practice standards within a reasonable time frame and relatively modest additional cost. The Irish administration already incurs many of the fixed and ongoing costs associated with modern accrual-based accounting and risk-based fiscal management. The CSO already prepares a consolidated general government financial balance sheet. All government departments, agencies, and local governments maintain registers of their fixed assets and produce partial operating statements and balance sheets. Actuarial estimates of public sector pension liabilities are periodically undertaken. Information about PPPs, guarantees, contingent liabilities, tax expenditures, and financial derivatives is regularly disclosed. The fact that this information is being collected, but is not being consolidated and published in comprehensive set of financial statements for the public sector and its sub-sectors, means that Ireland is not reaping the principal benefit from this effort. In the wake of the recent crisis which has seen general government's financial liabilities triple, financial assets rise by 40 percent, and contingent liabilities rise to over 136 percent of GDP, the benefit of having this more comprehensive overview of the public sector's net worth is that much greater.

Consolidating this information into a set of summary fiscal documents would put Ireland ahead of $E U$ reporting requirements, in line with international accounting standards, and at the forefront of fiscal transparency practice. Doing so would require a set of related actions over a period of years to:

- expand the institutional coverage of budgets, statistics, and accounts;

- recognize all assets, liabilities, and corresponding flows in fiscal reports;

- modernize the budget classification and chart of accounts;

- $\quad$ speed up the submission and approval of the annual budget and accounts;

- provide a detailed analysis of fiscal forecast changes and long-term trends;

- improve the reporting and management of fiscal risks; and

- harmonize financial reporting standards and practices across the public sector.

Over five years, these reforms would allow the government to:

- forecast and monitor its in-year performance against national and EU-wide fiscal rules and comply with the EU Six Pack and Two Pack requirements in 2013;

- publish its first fiscal sustainability report and statement of fiscal risks in 2014; 
- publish a trial consolidated Central Government Financial Statement for 2015;

- begin publishing fiscal statistics covering the entire public sector by 2016 ; and

- adopt accrual-based International Public Sector Accounting Standards (IPSAS) or their European variants by 2017.

Delivering these concrete improvements in fiscal reporting would enable the government to realize a number of benefits from enhanced fiscal disclosure by:

- providing more comprehensive, timely, and reliable data for fiscal decision-making;

- demonstrating the government's awareness and management of fiscal risks;

- promoting a more informed public debate on fiscal policy challenges and choices;

- reassuring markets of the overall sustainability of the public finances; and

- facilitating compliance with EU current and future fiscal reporting requirements.

Based on available data for 2011, the overall fiscal picture painted by this more comprehensive set of fiscal reports, summarized in Table 0.1 , is one in which:

- the central government deficit is 1.9 percent of GDP larger than that of the Exchequer owing to rundown of assets by extra-budgetary entities;

- the general government's net liabilities are 37.7 percent of GDP lower than its gross debt owing to its 73.5 percent of GDP in fixed assets and 39.2 percent of GDP in financial assets, which are partially offset by its 75.5 percent of GDP in public service pension and PPP liabilities; and

- the public sector has net liabilities of 68.7 percent of GDP, which is 37 percent of GDP higher than Canada, about the same as the UK, but 29 percent of GDP lower than that of the US Federal Government.

Table 0.1. Ireland: Public Sector Financial Overview, 2011 (Percent of GDP)

\begin{tabular}{|c|c|c|c|c|c|c|c|}
\hline & Exchequer & Central Govt & $\begin{array}{l}\text { Local } \\
\text { Govt }^{*}\end{array}$ & $\begin{array}{c}\text { General } \\
\text { Govt }\end{array}$ & $\begin{array}{l}\text { Public Non- } \\
\text { Fin Corps* }\end{array}$ & $\begin{array}{l}\text { Public Fin } \\
\text { Corps* }\end{array}$ & $\begin{array}{l}\text { Public } \\
\text { Sector }\end{array}$ \\
\hline \multicolumn{8}{|l|}{ Total Transactions } \\
\hline Revenue & 23.6 & 33.0 & 2.1 & 35.0 & 6.0 & 8.6 & 49.6 \\
\hline Expenditure & 35.4 & 46.6 & 2.1 & 48.6 & 5.6 & 6.3 & 60.5 \\
\hline Balance & -11.7 & -13.6 & 0.0 & -13.6 & 0.4 & 2.3 & -10.9 \\
\hline Total Assets & - & 47.8 & 64.9 & 112.7 & 11.8 & 192.4 & 316.9 \\
\hline Non-financial Assets & - & 9.8 & 63.6 & 73.5 & 14.2 & 0.5 & 88.1 \\
\hline Financial Assets & - & 38.0 & 1.2 & 39.2 & -2.3 & 191.9 & 228.8 \\
\hline Total Liabiltiies & - & 179.4 & 2.0 & 181.4 & 11.8 & 192.4 & 385.7 \\
\hline PPPs & - & 2.5 & - & 2.5 & - & - & 2.5 \\
\hline Public Service Pension & - & 73.0 & - & 73.0 & - & - & 73.0 \\
\hline Other & - & 103.9 & 2.0 & 105.9 & 11.8 & 192.4 & 310.2 \\
\hline Net Financial Worth & - & -141.4 & -0.7 & -142.2 & -14.2 & -0.5 & -156.8 \\
\hline Net Worth & - & - & - & -68.7 & 0.0 & 0.0 & -68.7 \\
\hline \multicolumn{8}{|l|}{ Memo } \\
\hline \multicolumn{4}{|c|}{ General government Gross Debt (ESA95) } & 106.4 & & & \\
\hline \multicolumn{4}{|l|}{ Net Debt } & 94.9 & & & \\
\hline
\end{tabular}

${ }^{*}$ Consolidated Position

Source: Estimates derived from DoF internal data and company reports, resulting in minor differences with CSO figures. 
Table 0.2. Ireland: Summary Assessment against Fiscal Transparency Code

\begin{tabular}{|c|c|c|}
\hline 1. Fiscal Reporting & $\begin{array}{l}\text { 2. Fiscal Forecasting \& } \\
\text { Budgeting }\end{array}$ & $\begin{array}{l}\text { 3. Fiscal Risk Analysis \& } \\
\text { Management }\end{array}$ \\
\hline 1.1. Coverage of Institutions & 2.1. Unity & 3.1. Macroeconomic Risks \\
\hline 1.2. Coverage of Stocks & 2.2. Gross Budgeting & 3.2. Specific Fiscal Risks \\
\hline 1.3. Coverage of Flows & $\begin{array}{l}\text { 2.3. Macroeconomic } \\
\text { Forecasts }\end{array}$ & $\begin{array}{l}\text { 3.3. Comparability of Forecasts } \\
\text { \& Outturns }\end{array}$ \\
\hline 1.4.Tax Expenditures & $\begin{array}{l}\text { 2.4. Medium-term Budget } \\
\text { Framework }\end{array}$ & 3.4. Contingency Reserves \\
\hline $\begin{array}{l}\text { 1.5. Frequency of In-year } \\
\text { Fiscal Reports }\end{array}$ & 2.5. Fiscal Strategy Report & $\begin{array}{l}\text { 3.5. Asset and Liability } \\
\text { Management }\end{array}$ \\
\hline $\begin{array}{l}\text { 1.6. Timeliness of Annual } \\
\text { Financial Statements }\end{array}$ & 2.6. Budget Submission & 3.6. Guarantees \\
\hline 1.7. Classification & 2.7. Budget Approval & 3.7. Financial Sector Exposure \\
\hline 1.8. Internal Consistency & 2.8. Fiscal Policy Objectives & 3.8. Long-Term Contracts \\
\hline 1.9. Historical Consistency & $\begin{array}{l}\text { 2.9. Separation of Existing } \\
\text { and New Policies }\end{array}$ & 3.9. Financial Derivatives \\
\hline $\begin{array}{l}\text { 1.10. Statistical } \\
\text { Independence }\end{array}$ & $\begin{array}{l}\text { 2.10. Performance } \\
\text { Information }\end{array}$ & $\begin{array}{l}\text { 3.10. Sub-National } \\
\text { Governments }\end{array}$ \\
\hline 1.11. External Audit & 2.11. Distributional Analysis & 3.11. Public Corporations \\
\hline \multirow[t]{3}{*}{ 1.12. Reliability } & $\begin{array}{l}\text { 2.12. Fiscal Sustainability } \\
\text { Analysis }\end{array}$ & \\
\hline & $\begin{array}{l}\text { 2.13. Independent Evaluation } \\
\text { 2.14. Supplementary Budget }\end{array}$ & \\
\hline & 2.15. Forecast Reconciliation & \\
\hline
\end{tabular}

\begin{tabular}{|c|}
\hline Practices \\
\hline Advanced \\
\hline Good \\
\hline Basic \\
\hline Not Met \\
\hline
\end{tabular}




\section{Fiscal Reporting}

\subsection{Introduction}

1. Fiscal reports should provide a comprehensive, timely, reliable, comparable, and accessible summary of the government's financial performance and position. To do so, fiscal reports, which comprise budget execution reports, fiscal statistics, and government accounts, should:

- cover all institutional units engaged in fiscal activity;

- capture all assets, liabilities, revenue, expenditure, financing, and other flows;

- be published in a frequent and timely manner;

- be classified according to an internationally recognized classification system;

- reconcile any unexplained discrepancies within or between fiscal reports; and

- be prepared by an independent agency (in the case of statistics) or scrutinized by an independent national audit institution (in the case of accounts).

2. Fiscal reporting in Ireland is characterized by a high degree of disclosure but also a high degree of fragmentation. Ireland's main in-year and annual fiscal reports cover different institutions, include different flows and stocks, are prepared on different accounting bases, and are classified according to different standards. Ireland's main summary fiscal reports, summarized in Table 1.1, comprise:

- monthly budget execution reports, in the form of the Department of Finance's (DoF's) traditional Exchequer Statements which cover only the cash inflows and outflows of the central government's main treasury account, the Central Fund, and the recently developed Alternative Exchequer Statement, which extends the coverage to the Social Insurance Fund (SIF) and National Training Fund (NTF). Both reports follow a traditional classification which conflates "above the line" nonfinancial and "below the line" financial transactions;,

- quarterly fiscal statistics published by the CSO and CBI which provide data on ESA95 general government borrowing and debt but not revenue and expenditure;

- semi-annual Excessive Deficit Procedure (EDP) notification produced by the CSO which provides more detailed information on the composition of ESA95 general government borrowing and debt;

\footnotetext{
${ }^{3}$ Under the ESA95/GFSM2001 framework, nonfinancial transactions include all transactions in revenue, expense and nonfinancial assets (such as buildings). Financial transactions include all transactions in financial assets (such as shares) and liabilities (such as bonds). Net lending/borrowing equals the net acquisition of financial assets minus the net incurrence of liabilities.
} 
- annual fiscal statistics which are published by Eurostat with a one quarter lag and provide a more detailed summary of ESA95 general government revenue, expenditure, deficit, and debt;

- annual Finance Accounts which provide a cash-based record of the transactions of the Central Fund as well as supplementary information on financial assets, national debt, guarantees, and derivative holdings; and

- annual Appropriation Accounts which provide a cash-based outturn and include in the notes an operating cost statement and a partial balance sheet for each of the 40 appropriations ("Votes") authorized by Parliament in the annual budget Estimates ${ }^{4}$ but do not combine them into a consolidated statement for the central government as a whole.

3. This chapter assesses the quality of Ireland's fiscal reporting practices against those set out in the IMF's Fiscal Transparency Code. In doing so it separately considers the following dimensions of fiscal disclosure:

i. coverage of institutions, stocks, and flows;

ii. frequency and timeliness of reporting;

iii. quality and consistency of fiscal reporting; and

iv. reliability of fiscal reports.

\footnotetext{
${ }^{4}$ The Appropriation Accounts do not include a full operating statement or a full balance sheet. However, for each Vote some information of an accruals nature is included in the notes. The notes include an operating cost statement that gives information on the cost of the service provided for the year by the Vote-funded department or agency. The notes also incorporate information on (i) liabilities other than liabilities in regard to pensions; and (ii) financial and fixed assets recorded at historical cost, but these are not consolidated into an overall balance sheet for the central government. Changes in the value of assets and liabilities are also not reflected in the balance sheets.
} 
Table 1.1. Ireland: List of Fiscal Reports

\begin{tabular}{|c|c|c|c|c|c|c|c|c|}
\hline \multirow[b]{2}{*}{ REPORT } & \multicolumn{3}{|c|}{ COVERAGE } & \multicolumn{3}{|c|}{ ACCOUNTING } & \multicolumn{2}{|c|}{ PUBLICATION } \\
\hline & Institutions & Flows & Stocks & Basis & Class & $\begin{array}{l}\text { Non-tax } \\
\text { Rev }\end{array}$ & Freq & Date \\
\hline \multicolumn{9}{|c|}{ IN-YEAR REPORTS } \\
\hline $\begin{array}{c}\text { Monthly } \\
\text { Exchequer } \\
\text { Statements } \\
\end{array}$ & BCG & $\begin{array}{l}\text { Rev, } \\
\text { Exp, Fin }\end{array}$ & None & Cash & Nat & Net & Mo & $\begin{array}{l}2 \text { day } \\
\text { lag }\end{array}$ \\
\hline $\begin{array}{l}\text { Analytical } \\
\text { Exchequer } \\
\text { Statement }\end{array}$ & BCG & $\begin{array}{l}\text { Rev, } \\
\text { Exp }\end{array}$ & None & Cash & Nat & Gross & Mo & $\begin{array}{l}2 \text { day } \\
\text { lag }\end{array}$ \\
\hline $\begin{array}{c}\text { Quarterly Fiscal } \\
\text { Statistics }\end{array}$ & GG & Bal & Debt & Part Acc & $\begin{array}{c}\text { ESA } \\
95\end{array}$ & Gross & Qtr & Qtr lag \\
\hline $\begin{array}{c}\text { Maastricht EDP } \\
\text { Returns }\end{array}$ & GG & Bal & Debt & Part Acc & $\begin{array}{c}\text { ESA } \\
95\end{array}$ & $\mathrm{~N} / \mathrm{A}$ & $6 \mathrm{Mo}$ & $\begin{array}{l}\text { Mar } \\
\text { Sep }\end{array}$ \\
\hline \multicolumn{9}{|c|}{ YEAR-END REPORTS } \\
\hline $\begin{array}{c}\text { Annual Fiscal } \\
\text { Statistics }\end{array}$ & GG & $\begin{array}{l}\text { Rev, Exp, } \\
\text { Fin }\end{array}$ & $\begin{array}{c}\text { Fin } \\
\text { Assets, } \\
\text { Liab }\end{array}$ & Part Acc & $\begin{array}{c}\text { ESA } \\
95\end{array}$ & Gross & Ann & Qtr lag \\
\hline $\begin{array}{l}\text { Finance } \\
\text { Accounts }\end{array}$ & BCG & $\begin{array}{l}\text { Rev, Exp, } \\
\text { Fin }\end{array}$ & $\begin{array}{c}\text { Fin } \\
\text { Assets, } \\
\text { Liab, Guar } \\
\end{array}$ & Cash & Nat & Gross & Ann & Sep \\
\hline $\begin{array}{l}\text { Appropriation } \\
\text { Accounts }\end{array}$ & BCG & Exp & $\begin{array}{l}\text { Assets, } \\
\text { Liab }\end{array}$ & $\begin{array}{l}\text { Mod } \\
\text { Cash }\end{array}$ & Nat & Gross & Ann & Sep \\
\hline \multicolumn{9}{|c|}{ FISCAL FORECASTS } \\
\hline \multirow{2}{*}{$\begin{array}{c}\text { Stability } \\
\text { Program Update }\end{array}$} & BCG & Rev, Exp & None & Cash & Nat & Gross & \multirow[b]{2}{*}{ Ann } & \multirow[b]{2}{*}{ Apr } \\
\hline & GG & Rev, Exp & Debt & Part Acc & $\begin{array}{c}\text { ESA } \\
95\end{array}$ & Gross & & \\
\hline \multirow{2}{*}{$\begin{array}{c}\text { Medium-term } \\
\text { Fiscal } \\
\text { Statement }\end{array}$} & BCG & Rev, Exp & None & Cash & Nat & Gross & \multirow[b]{2}{*}{ Ann } & \multirow[b]{2}{*}{ Nov } \\
\hline & GG & Rev, Exp & Debt & Part Acc & $\begin{array}{c}\text { ESA } \\
95\end{array}$ & Gross & & \\
\hline \multicolumn{9}{|l|}{ BUDGETS } \\
\hline \multirow{2}{*}{$\begin{array}{c}\text { White Paper on } \\
\text { Receipts and } \\
\text { Expenditure }\end{array}$} & BCG & Rev, Exp & None & Cash & Nat & Net & \multirow[b]{2}{*}{ Ann } & \multirow[b]{2}{*}{ Dec } \\
\hline & GG & Bal & None & Part Acc & $\begin{array}{c}\text { ESA } \\
95\end{array}$ & N/A & & \\
\hline \multirow{2}{*}{$\begin{array}{l}\text { Budget } \\
\text { Economic and } \\
\text { Fiscal Outlook }\end{array}$} & $\mathrm{BCG}$ & Rev, Exp & None & Cash & Nat & Gross & \multirow{2}{*}{ Ann } & \multirow{2}{*}{$\mathrm{Dec}$} \\
\hline & GG & $\begin{array}{c}\text { Rev, Exp, } \\
\text { Bal }\end{array}$ & Debt & Part Acc & $\begin{array}{c}\text { ESA } \\
95\end{array}$ & $\mathrm{~N} / \mathrm{A}$ & & \\
\hline $\begin{array}{c}\text { Expenditure } \\
\text { Report \& } \\
\text { Estimates for } \\
\text { Public Services }\end{array}$ & BCG & Exp & None & Cash & Nat & Gross & Ann & $\mathrm{Dec}$ \\
\hline
\end{tabular}

Note: BCG: Budgetary Central Government; CG: Central Government, GG: General Government

\subsection{Coverage of Fiscal Reports}

\subsubsection{Coverage of public sector institutions (Good)}

4. Ireland's public sector comprises 624 separate institutional entities. Table 1.2 lists the number of institutional units in each sub-sector of the public sector and shows that:

- budgetary central government ("the Exchequer") comprises the 40 central government departments and offices who have their expenditure authorized by Parliament through the annual Estimates/Appropriations and other constitutionally 
independent entities funded through standing charges on the Central Fund, such as the Oireachtas (Parliament) and judicial salaries;

- extra-budgetary central government comprises 128 entities including 2 social security funds (the Social Insurance Fund and National Training Fund), 43 extrabudgetary funds, and 83 non-market semi-state agencies. Most of these entities receive some direct grant from the Exchequer in addition to revenue they raise through investment income, fees, and charges;

- local government comprises 391 entities, including 114 local authorities, 10 regional authorities/assemblies, and 34 entities in the vocational education sector. All these depend largely on grants from central government for revenue. There are also 233 local public enterprises that are subsidiaries of local authorities; and

- public corporations, which are majority public owned or controlled, comprise 62 entities of which 57 are nonfinancial corporations and 5 are financial corporations (including the Central Bank of Ireland).

Table 1.2. Ireland Public Sector: Institutional Composition and Finances, 2011 (Percent of GDP)

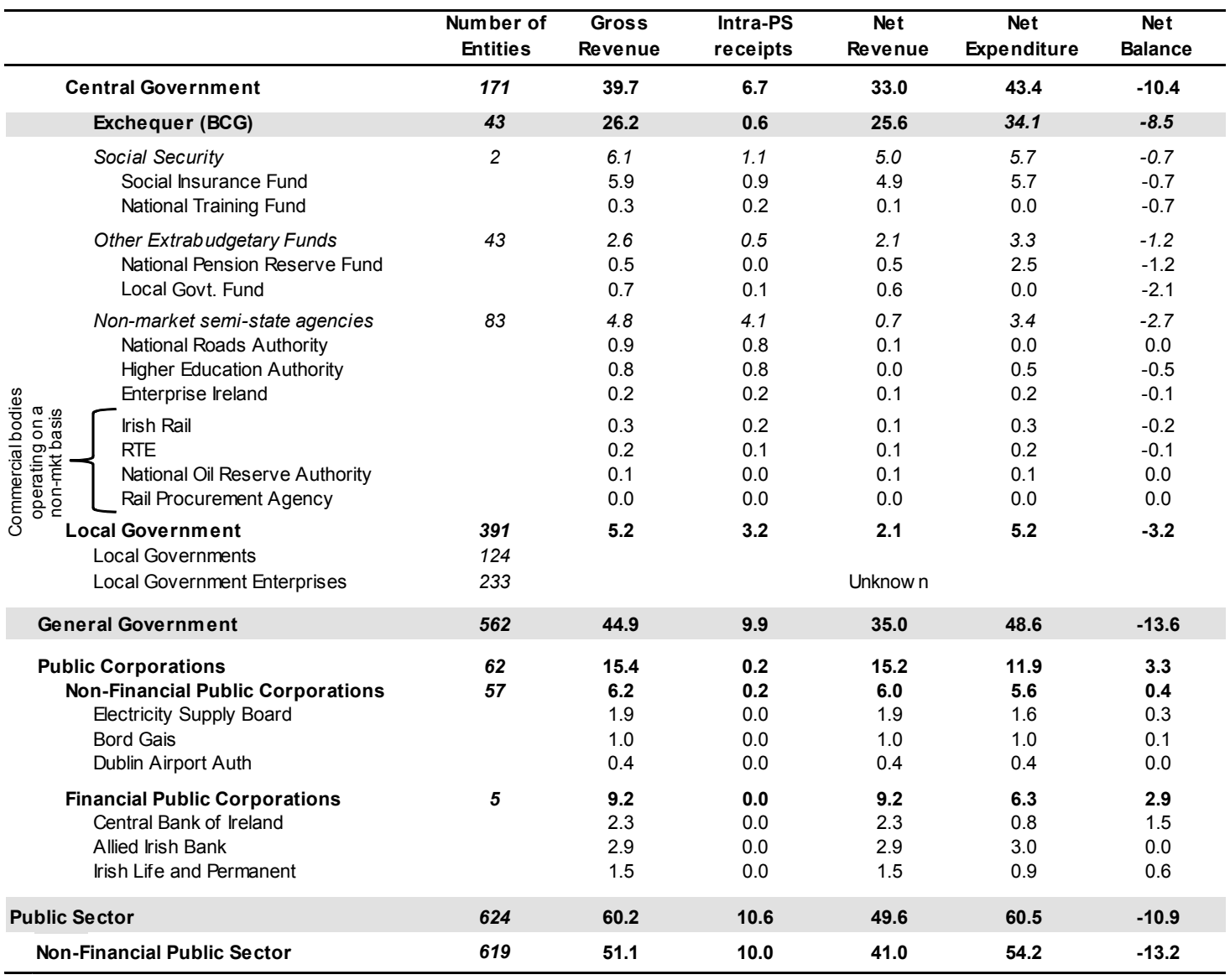

Source: Staff estimates derived from Ministry of Finance internal data and company annual reports. 
5. Ireland's public sector accounted for around 60 percent of GDP by expenditure in 2011. Table 1.2 also summarizes the distribution of public resources across the different sub-sectors of the public sector in 2011 and shows that:

- central government expenditure accounts for 43 percent of GDP of which 30 percent of GDP flows through the central government budget, 6 percent comes from the two social security funds, 3 percent is spent through various extrabudgetary funds (principally the National Pension Reserve Fund), and another 3 percent is spent by non-market semi-state agencies such as the National Roads Authority, Irish Rail, and Radio Telefis Eireann (RTE);

- local government accounts for 5 percent of GDP, though this includes only the direct expenditure of the authorities themselves and not their enterprises;

- general government, which consolidates central and local governments and is the reporting entity for European fiscal statistics and surveillance purposes, accounts for 48.6 percent of GDP; and

- public corporations account for a further 12 percent of GDP of which 6 percent of GDP is spent by financial corporations, and another 6 percent comes from nonfinancial corporations.

\section{Ireland's most comprehensive fiscal reports cover the consolidated general} government in line with EU reporting requirements. The CSO's quarterly and annual fiscal statistics for the general government account for 81 percent of public sector expenditure. However, monthly fiscal reports confine themselves to the cash receipts and payments of the Exchequer which accounts for just 70 percent of public sector expenditure. Budget documentation in the form of the Stability Program Update (SPU), Medium-Term Fiscal Statement (MTFS), and Budget Economic and Fiscal Outlook include a reconciliation (or "walk") from the annual Exchequer to general government balance but do not do the same for gross expenditure and revenue. A clearer understanding of the relationship between gross Exchequer expenditure and gross general government expenditure will be essential if Ireland is to ensure that budgetary decisions are consistent with the new general government expenditure benchmark included in the EU's "Six Pack" of fiscal governance reforms.

\section{Ireland's relatively large public corporations sector remains outside both} Finance Accounts and fiscal statistics as shown in Figure 1.1. The 19 percent of public expenditure by public corporations is dominated by public utilities such as the Electricity Supply Board, Bord Gais (Gas Board), and Coras Iompair Eireann (CIE or Irish Transport Authority), the four financial institutions (IBRC, NAMA, Allied Irish Bank, and Irish Life and Permanent) acquired by the government in the wake of the 2008 financial crisis, and the Central Bank of Ireland. ${ }^{5}$

\footnotetext{
${ }^{5}$ Public corporations are commercial entities which are either majority owned or controlled by government. Figures for expenditure by public corporations relate to 2011. However, institutional arrangements within this sector are very fluid, with the government recently liquidating IBRC and selling Irish Life.
} 
Figure 1.1. Ireland: Coverage of Public Sector Institutions in Fiscal Reports (Percent of Expenditure)

Finance Accounts

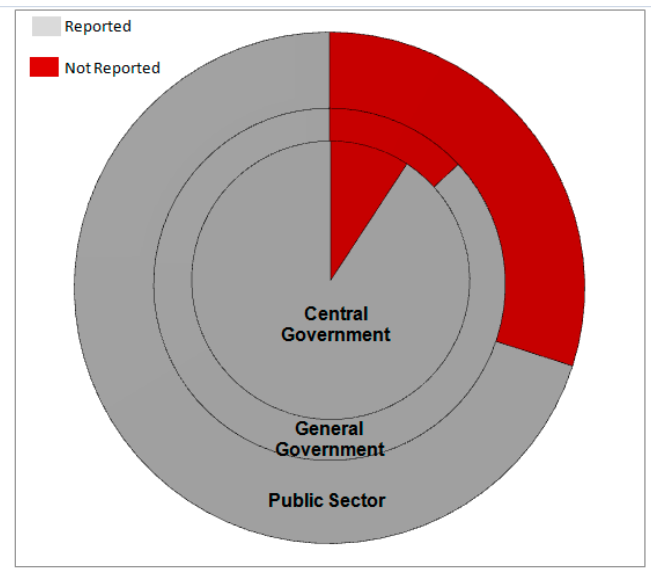

Fiscal Statistics

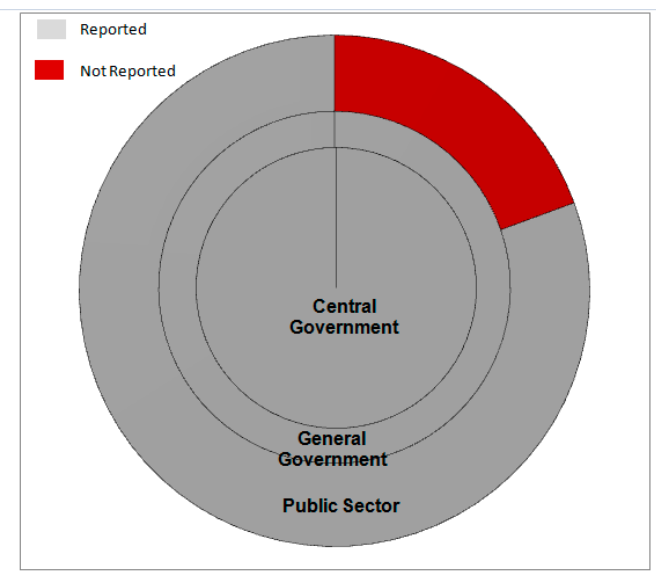

Source: Staff estimates.

8. Expanding the institutional coverage of Ireland's fiscal reporting from the general government to encompass the entire public sector results in a modest improvement in the overall balance in 2011. Public corporations add a further 12 percent of GDP to expenditure and 15 percent of GDP to revenue, reducing the overall balance from $13 \frac{1}{2}$ percent of GDP to 11 percent of GDP. This is due in large part to the operating profits (before impairments) being made by government-controlled financial corporations. However, as discussed in more detail in the next section, while the revenues and expenditure of Ireland's public corporations make a relatively modest contribution to public sector flows, their liabilities (and assets) are very large both relative to the liabilities of the Irish government and compared with the public corporations sector of other advanced countries (Figure 1.2). Understanding the financial position of these entities and their relationship with the government is critical to understanding the overall financial position and sustainability of Ireland's public sector.

Figure 1.2. Ireland: Public Sector Gross Liabilities

(Percent of GDP)

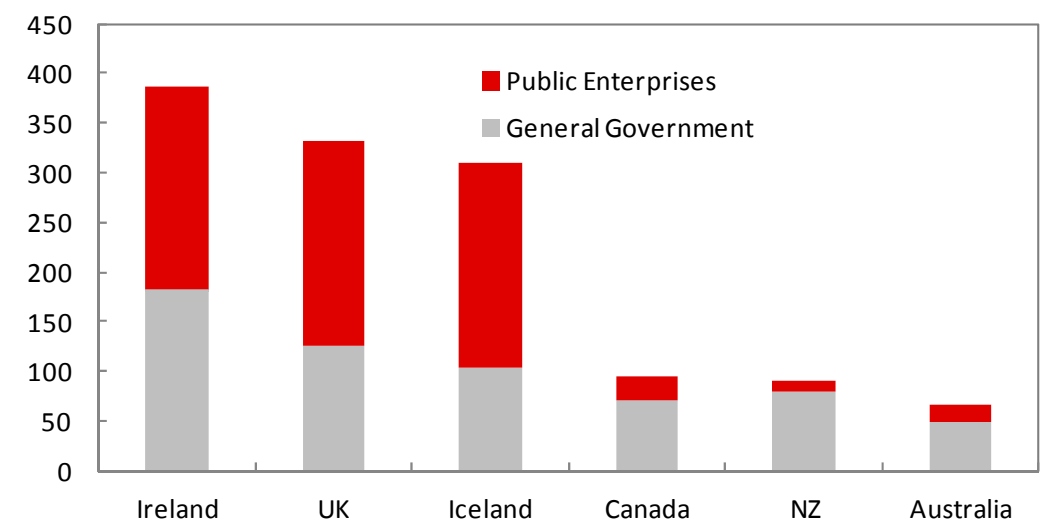




\subsubsection{Coverage of assets and liabilities (Good)}

9. The Irish public sector's holdings of assets and liabilities are large and have expanded considerably since the $\mathbf{2 0 0 8}$ crisis. As shown in Figure 1.3, Ireland's public sector asset holdings are estimated to be around 317 percent of GDP and its liabilities are estimated to be around 386 percent of GDP in 2011. Within this:

- general government has financial assets of 39 percent of GDP and recognized liabilities of 106 percent of GDP, the bulk of which is central government debt;

- central and local governments have additional unrecognized liabilities of 73 percent of GDP in unfunded public service pension and PPP obligations, though this estimate dates back to 2009 , the last time the liability was calculated;

- central government's recorded holdings of fixed assets are relatively modest at 9 percent of GDP, though their value is likely underestimated due to the fact that they are held at historic cost on department's balance sheets;

- local government fixed assets account for 64 percent of GDP with roads and housing accounting for 35 and 13 percent respectively;

- public corporations have 192 percent of GDP in liabilities to the private sector but these are matched by 192 percent of GDP in fixed and financial assets; and

- intra-public sector holdings are substantial. Government equity holdings in all public corporations, public corporations' holdings of central government and NAMA bonds, and CBI Emergency Liquidity Assistance to public banks amount to 170 percent of GDP. Failing to take these crossholdings into account would provide an exaggerated picture of the public sector's liabilities.

Figure 1.3. Ireland: Public Sector Balance Sheet and Coverage in Fiscal Reports (Percent of GDP)

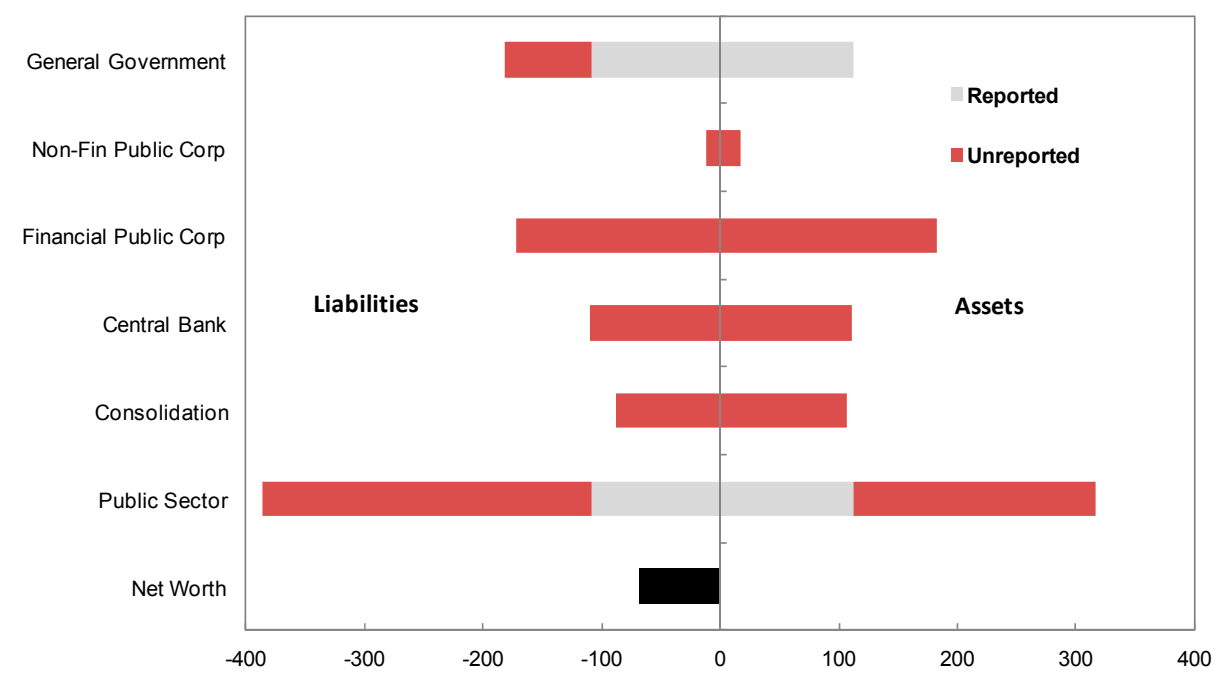

Source: Staff estimates. 
10. Ireland's estimated public sector net liabilities were 69 percent of GDP in 2011, not particularly high by advanced country standards. As shown in Figure 1.4, the UK public sector and US Federal Government have higher net liabilities, reflecting large public sector pension obligations and the fact that a sovereign government's greatest asset - the ability to tax-is not reflected in its balance sheet. There is also some reason to believe that the current net worth of the Irish public sector is actually higher than the estimate in Figure 1.4 on the grounds that:

- central and local government public service pension liabilities were last estimated in 2009 , prior to a series of significant structural reforms designed to improve the sustainability of the pensions regime; and

- central and local government holdings of fixed assets could be undervalued as most are recorded at historic costs on department and local government balance sheets.

Figure 1.4. Public Sector Net Worth in Selected Countries (Percent of GDP)

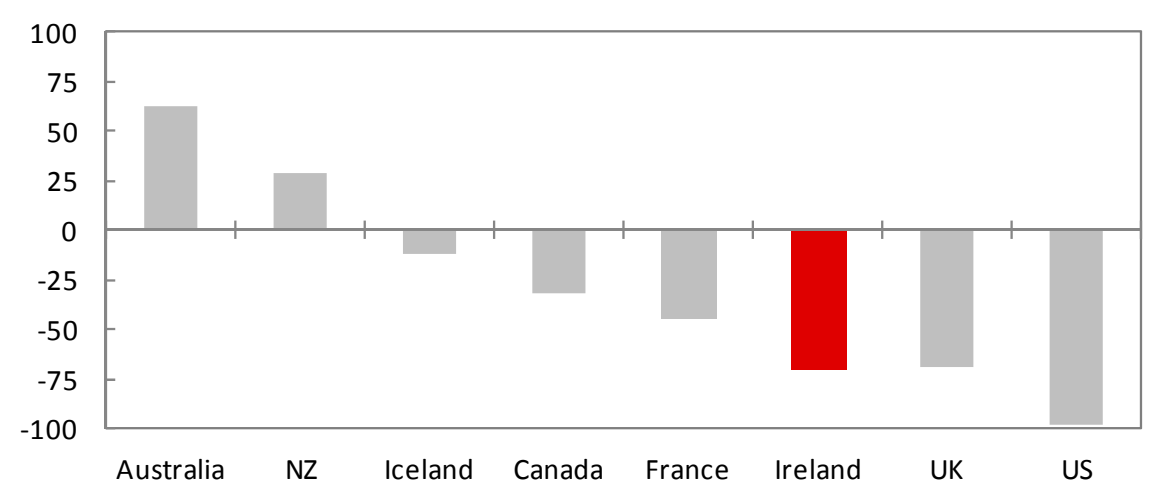

Source: Staff estimates, national budgets and statistical agencies.

Figure 1.5. Gross Public Sector Pension Liabilities in Selected Countries (Percent of GDP)

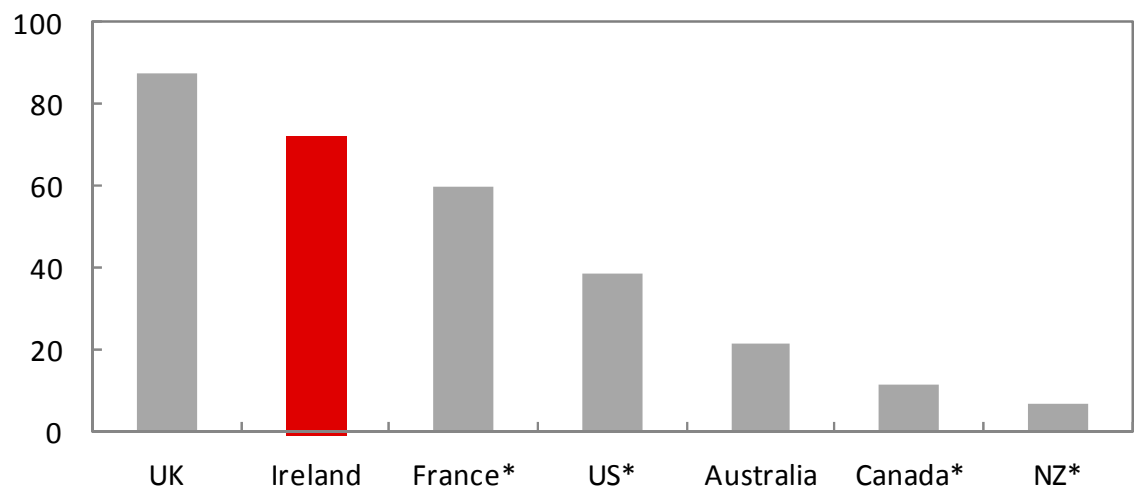

*Does not include local government pension liabilities.

Source: Various national financial statements. 
11. Ireland's fiscal reports include relatively little consolidated balance sheet information. Annual Finance Accounts include separate statements on Exchequer loans outstanding, shareholdings in corporations and international organizations, guaranteed liabilities, and debt, but include no consolidated balance sheet. The Appropriation Accounts include a balance sheet of liabilities and financial and fixed assets for each Vote-funded department or agency, but, as mentioned above, the latter are recorded at historical cost, and they are not consolidated into an overall balance sheet for the central government. Only the CSO's annual financial statistics present a consolidated financial balance sheet for the general government, which accounts for only 28 percent of the liabilities and 36 percent of the assets of the public sector (Figure 1.3). While there is currently no domestic in-year reporting on changes in government assets or liability holdings, the CSO plans to begin publishing a quarterly general government financial balance sheet from April 2013.

\section{Changes in the assets and liabilities of government-controlled financial} corporations have had a major impact on the Irish public finances in the wake of the crisis, which are not fully captured in current fiscal reports. The 2011 C\&AG Audit Report identified $€ 43$ billion (27.5 percent of 2010 GDP) in capital provided to governmentcontrolled credit institutions between 2008 and 2010 and the need for a further $€ 18.8$ billion (12 percent of GDP) in capital injections. More recently, the government agreed to sell its 100 percent equity stake in Irish Life in exchange for $€ 1.3$ billion ( 0.8 percent of GDP) in cash, subject to receipt of regulatory and competition approvals. However, as Ireland's fiscal reports cover only the general government and include limited real-time balance sheet information, government and the public are only provided a partial view of the fiscal implications of these transactions.

\subsubsection{Coverage of revenue, expenditure, and other flows (Basic)}

\section{Ireland's core fiscal reports are cash-based, but some accrual flows are} captured in fiscal statistics, in supplementary disclosures in the accounts of individual departments, and in local government accounts. DoF's monthly Exchequer Statements and annual Finance Accounts present only the cash inflows and outflows of the Central Fund account. While annual departmental Appropriation Accounts are also primarily cashbased, they do present some accrual flows such as payables and receivables, depreciation, inventories, and provisions for contingent liabilities. The CSO's quarterly and annual general government fiscal statistics include payables, receivables, and depreciation in line with ESA95 requirements. The net impact of these accrual adjustments in 2011 was to add a further 0.4 percent of GDP to revenue, take away 0.2 percent of GDP from expenditure, and reduce net lending by 0.6 percent of GDP (Table 1.3 ). 
Table 1.3. Ireland: Cash to Accrual Adjustments (Percent of GDP)

\begin{tabular}{|c|c|c|}
\hline & 2010 & 2011 \\
\hline Receipts & 0.0 & 0.4 \\
\hline Within ESA 95 & 0.0 & 0.4 \\
\hline Taxes & 0.0 & 0.3 \\
\hline UMTS licences & 0.0 & 0.0 \\
\hline Accrued interest on contingent capital in banks & 0.0 & 0.1 \\
\hline EU transfers & 0.0 & 0.0 \\
\hline Payments & 1.5 & 0.4 \\
\hline Within ESA 95 & 0.4 & -0.2 \\
\hline Accrued but unpaid interest & 0.9 & 0.0 \\
\hline Other voted expenditure & -0.2 & 0.0 \\
\hline Military expenditure & 0.0 & 0.0 \\
\hline Farm Waste Management Scheme & -0.2 & 0.0 \\
\hline Departmental balances & 0.0 & 0.0 \\
\hline Capital carryover system & 0.1 & -0.1 \\
\hline Payment to Departmental holding account & -0.1 & 0.0 \\
\hline HSE accrual & -0.1 & -0.1 \\
\hline Outside ESA 95 & 1.1 & 0.7 \\
\hline Net accrued pension liabilities & 0.7 & 0.7 \\
\hline Construction of PPP projects & 0.4 & 0.0 \\
\hline \multicolumn{3}{|l|}{ Fiscal Balances } \\
\hline Cash Balance & -30.4 & -13.8 \\
\hline ESA 95 Balance & -30.9 & -13.3 \\
\hline Full Accrual Balance & -32.0 & -13.9 \\
\hline Other Economic Flows & 10.3 & -6.5 \\
\hline Change in value of financial assets & 0.5 & -3.4 \\
\hline less change in value of financial liabilities & -9.8 & 3.1 \\
\hline Change in Net Worth (full accrual) & -21.7 & -20.5 \\
\hline
\end{tabular}

Source: CSO, DoF, and staff estimates.

\section{Nonetheless, other significant accrued flows remain outside summary fiscal} data or are based on statistical models rather than accounting data. Most of these missing flows are linked to changes in the value of assets and liabilities that are also missing from government balance sheets. ${ }^{6}$ These include:

- the annual net accrual of public service pension liabilities - including the net accrual of liabilities less cash payments of previously accrued liabilities plus the nominal

\footnotetext{
${ }^{6}$ In common with most other EU countries (even those which have adopted full accrual accounting for expenditures), Ireland's fiscal statistics make some accrual adjustments to reported government revenues to account for discrepancies between the timing that an obligation is due and the time at which it is paid but do not strictly apply accrual principles to the recording of taxes and other non-exchange transactions.
} 
interest on unfunded liabilities — estimated by staff at $€ 1$ billion ( 0.7 percent of GDP) in 2011 which is not reflected in any summary fiscal report;

- annual investments in PPPs under construction which are estimated at $€ 0.7$ billion ( 0.4 percent of GDP) in 2010 but which fell to zero in 2011 as existing projects were completed and no new projects were initiated. Unlike the unitary charges associated with completed PPP projects, these are not reflected in statistics and accounts;

- accurate figures for depreciation of fixed assets. The CSO's estimated depreciation of $€ 2.5$ billion (1.6 percent of GDP) in 2011 general government fiscal statistics is based on a perpetual inventory model and not taken from the fixed asset registers maintained by central and local government departments. The difference between the two figures amounted to 1.4 percent of GDP in 2011; and

- valuation changes on the government's substantial holding of financial assets, which amounted to a loss of $€ 5.4$ billion (3.4 percent of GDP) in 2011, are captured in government financial statistics but not in the government's Finance or Appropriation Accounts.

\subsubsection{Tax expenditures (Basic)}

15. Ireland publishes information on the estimated revenue foregone from some but not all tax expenditures. The Revenue Commissioners' Annual Statistical Reports includes a list of the revenue foregone from income and corporation tax allowances, reliefs, and deductions for 2009. However, the cost of targeted exemptions, reduced rates, credits, or allowances related to other taxes such as VAT, CGT, or stamp duty are not included. More comprehensive, independent estimates of the size of tax expenditures in Ireland put the net revenue foregone from all direct and indirect tax allowances, reliefs, deductions, and rebates at around 6 percent of GDP or 18 percent of the total tax take in $2006 .^{7}$ This revenue loss is large by the standards of other OECD countries, as shown in Figure 1.6. Some of the most fiscally significant reliefs - such as CGT exemption on principal private residences, mortgage interest income tax relief, and property investment incentives-likely contributed to the residential property boom that preceded the 2008 crisis and have since been substantially curtailed or abolished.

\footnotetext{
${ }^{7}$ Collins and Walsh (2010), Ireland's Tax Expenditure System: International Comparisons and a Reform Agenda, The Policy Institute, Studies in Public Policy: 25.
} 
Figure 1.6. Revenue Loss from Tax Expenditures

(Percent of GDP)

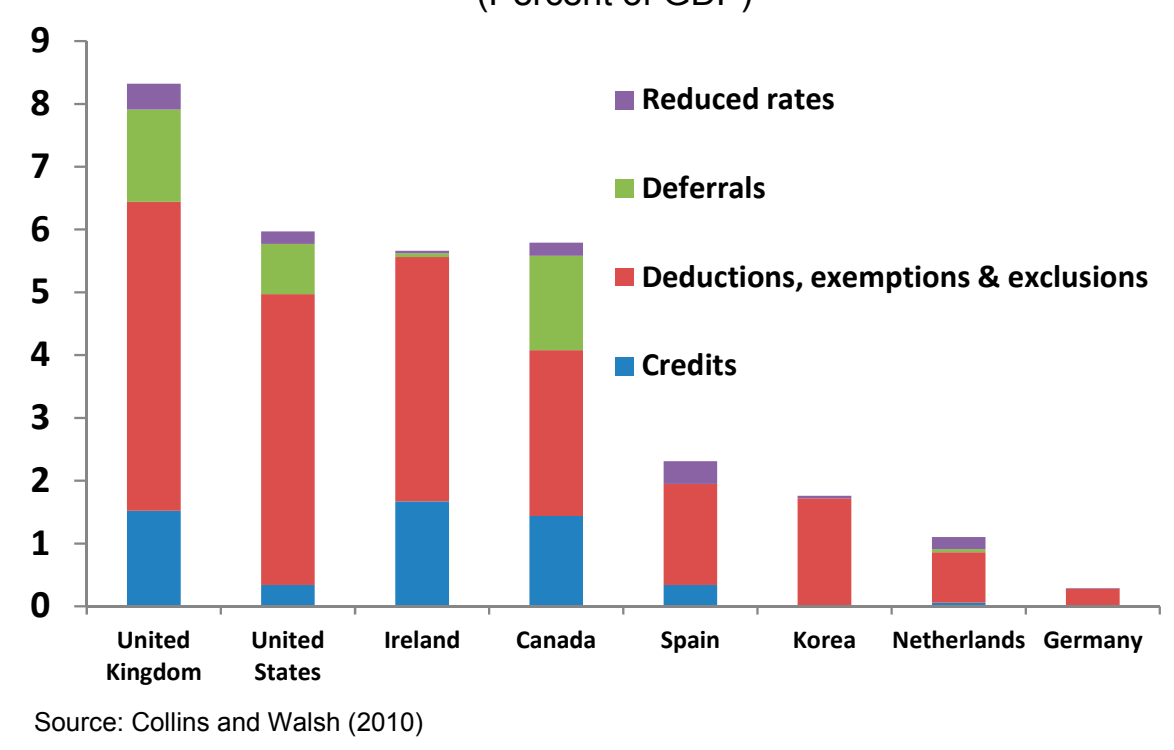

\subsection{Frequency and Timeliness of Fiscal Reporting}

\subsubsection{Frequency of in-year reports (Advanced)}

16. Ireland's budget execution reports are produced with a high degree of frequency and timeliness but general government statistics are available only on a quarterly basis. The DoF's cash-based Exchequer statements are produced on a monthly basis and within two days of the end of each month. In-year reporting of some general government fiscal aggregates on ESA95 basis is scattered across a number of different publications including (i) the CSO's quarterly nonfinancial accounts; (ii) the CSO's quarterly national accounts; and (iii) the CBI's quarterly financial accounts. However, from April 2013, the CSO will begin publishing an accrual-based general government flow statement and balance sheet on a quarterly basis with a three-month lag. In line with the requirements of the EU Six Pack, the DoF also plans to begin publishing monthly cashbased general government flow data from 2014.

\subsubsection{Timeliness of annual financial statements (Good)}

17. Ireland's audited annual accounts of central government are published within nine months of the end of the financial year. Ireland produces two sets of audited annual accounts. The Appropriation Accounts are prepared for each Vote by the respective Accounting Officers by end-March and audited by the C\&AG by end-September each year. The Appropriation Accounts compare the Supply Estimate voted by Parliament for each Department under the Appropriation Act with the actual payments made and receipts brought to account, and explains any substantial differences. The Finance Accounts, which are produced by end-June and audited by the C\&AG and published by end-September each year, provide a record of cash receipts and issues of the Exchequer Central Fund and the issuance and redemption of national debt. The current nine-month lag between the end of financial year and publication of the audited year-end accounts, while in accordance with 
the statutory timetable, is longer than other developed countries. It offers limited opportunity for their use in the preparation of next year's budget which, under the government's revised timetable, will be submitted to Parliament in October from this year. The Irish authorities intend to improve the timeliness of annual central government accounts, but no formal decision has been taken. Audit of local government accounts is performed by the Local Government Audit Service and there is currently a 15-month lag between the end of the financial year and the completion of the audit.

\subsection{Quality of Fiscal Reports}

\subsubsection{Classification (Good)}

18. Fiscal statistics comply with ESA95 classifications for aggregates reporting despite multiple and inconsistent charts of accounts being used by different general government entities. The statistics produced by the CSO under the EDP procedure, e.g., the Maastricht Returns, meet the ESA95 classification requirements for reporting of fiscal aggregates such as general government balance and debt. On an annual basis, the CSO also produces data complying for the most part with GFSM 2001 economic classification for inclusion in the IMF's Government Finance Statistics Year Book. The Exchequer Statement and Finance Accounts present data using a more traditional presentation which conflates financial (below the line) and nonfinancial (above the line) transactions, making it difficult to reconcile them with ESA95 statistics for general government (Table 1.4). Annual departmental Appropriation Accounts present information in two formats: one which follows the administrative and economic categories set out in their budget Estimate and one which follows an adaptation of private sector Financial Reporting Standards for the UK and Ireland that broadly meets international standards with minor gaps. Local governments follow their own classification system set out in the Local Authority Accounting Code of Practice. Non-commercial semi-state bodies and public corporations have their own charts of accounts which do not map directly to those used by either central or local government.

\section{The lack of harmonization between the charts of accounts for all general} government entities is an obstacle to the production of more detailed, timely, and reliable fiscal data for the general government. Collection and consolidation of ESA95 general government data for fiscal surveillance purposes cannot be done directly from the accounting systems used by central government departments, local governments, and other general government entities. Instead it requires extensive manual manipulation to reclassify data and consolidate out intra-governmental stocks and flows. This increases the risk of double counting of assets and liabilities across general government units, as happened in the case debt issued by the NTMA to the Housing Finance Agency which was mistakenly counted as being held outside the general government between 2007 and 2011 . This resulted in Ireland's general government gross debt being overstated by $€ 3.6$ billion ( 2.3 percent of GDP) at the end of 2011. Detailed control reviews and improvements have occurred since then, including three published reports into the error. The lack of a comprehensive and exhaustive program classification also blurs the line of sight between policy objectives, resource allocations, expenditures, and outcomes and makes it difficult to prepare COFOGbased statistics on the functional distribution of expenditure without resort to estimation. 
Table 1.4. Ireland: National Classification vs. International Standards

\begin{tabular}{|c|c|c|c|}
\hline Classification & Purpose & $\begin{array}{l}\text { International } \\
\text { Standard }\end{array}$ & $\begin{array}{l}\text { Ireland Central Government } \\
\text { Departments }\end{array}$ \\
\hline Administrative & $\begin{array}{l}\text { Accountability and } \\
\text { budget administration by } \\
\text { Vote and cost center } \\
\text { Example: Ministries, } \\
\text { departments, agencies, } \\
\text { cost centers, budget } \\
\text { funded entities }\end{array}$ & $\begin{array}{l}\text { Specific to } \\
\text { each country }\end{array}$ & $\begin{array}{l}\text { Departmental Votes: Currently } \\
\text { numbered from } 1 \text { to } 43 \text { ( } 2011 \text { App. } \\
\text { Account) } \\
\text { Cost Centers. Each Dept/agency } \\
\text { has its own code for its cost centers }\end{array}$ \\
\hline Economic & $\begin{array}{l}\text { Control/monitoring of } \\
\text { fiscal aggregates, } \\
\text { macroeconomic analysis, } \\
\text { and statistical reporting }\end{array}$ & $\begin{array}{c}\text { GFSM } \\
\text { 2001/ESA } 95 \\
\text { IFRS/IPSAS }\end{array}$ & $\begin{array}{l}\text { Revenue and capital, and expense } \\
\text { classified by pay and non-pay, but } \\
\text { financial and non-financial } \\
\text { transactions not clearly } \\
\text { distinguished in accounts to comply } \\
\text { with GFSM 2001/ESA95 } \\
\text { Assets and liabilities are classified in } \\
\text { accounts, but not according to } \\
\text { IFRS/IPSAS }\end{array}$ \\
\hline $\begin{array}{l}\text { Functional } \\
\text { (and/or } \\
\text { Program) }\end{array}$ & $\begin{array}{l}\text { Historic analysis, policy } \\
\text { analysis and } \\
\text { comparisons, and policy } \\
\text { formulation and } \\
\text { performance } \\
\text { accountability }\end{array}$ & $\begin{array}{l}\text { Classification } \\
\text { of Functions of } \\
\text { Government } \\
\text { (COFOG) }\end{array}$ & $\begin{array}{l}\text { A functional classification is used in } \\
\text { budget documentation for current } \\
\text { expenditure (five functions), but not } \\
\text { for capital expenditure to fully map } \\
\text { all transactions to COFOG } \\
\text { Only some of the existing programs } \\
\text { could be mapped to a COFOG } \\
\text { sector }\end{array}$ \\
\hline Fund & $\begin{array}{l}\text { To identify source of } \\
\text { funding, facilitate } \\
\text { consolidation, and } \\
\text { separately report on all } \\
\text { public funds }\end{array}$ & $\begin{array}{l}\text { Specific to } \\
\text { each country }\end{array}$ & $\begin{array}{l}\text { Separate accounting is done for } \\
\text { each fund, e.g., Central Fund } \\
\text { No systematic coding of } \\
\text { counterparty sectors for transactions } \\
\text { to facilitate consolidation }\end{array}$ \\
\hline
\end{tabular}

\subsubsection{Internal consistency (Good)}

20. Ireland regularly publishes two of the three internal consistency checks called for under the Code. The April SPU and September MTFS include a reconciliation of the difference between the Exchequer borrowing requirement (EBR) and the annual change in the stock of general government debt for the current year and the next five years. The NTMA's Annual Report includes a complete reconciliation of the Exchequer surplus and the net Exchequer borrowing for the two previous years. While the Central Bank of Ireland collects and publishes data on both the issuance of central government debt and reported holdings of government debt by other sectors of the economy, there is no published reconciliation between the two. In the absence of a harmonized chart of accounts across general government entities, such a reconciliation of data for the stock of government debt 
in non-government hands would provide a further opportunity to identify and correct the kind of double-counting of general government debt mentioned above.

Figure 1.7. Ireland: Stock-Flow Adjustments

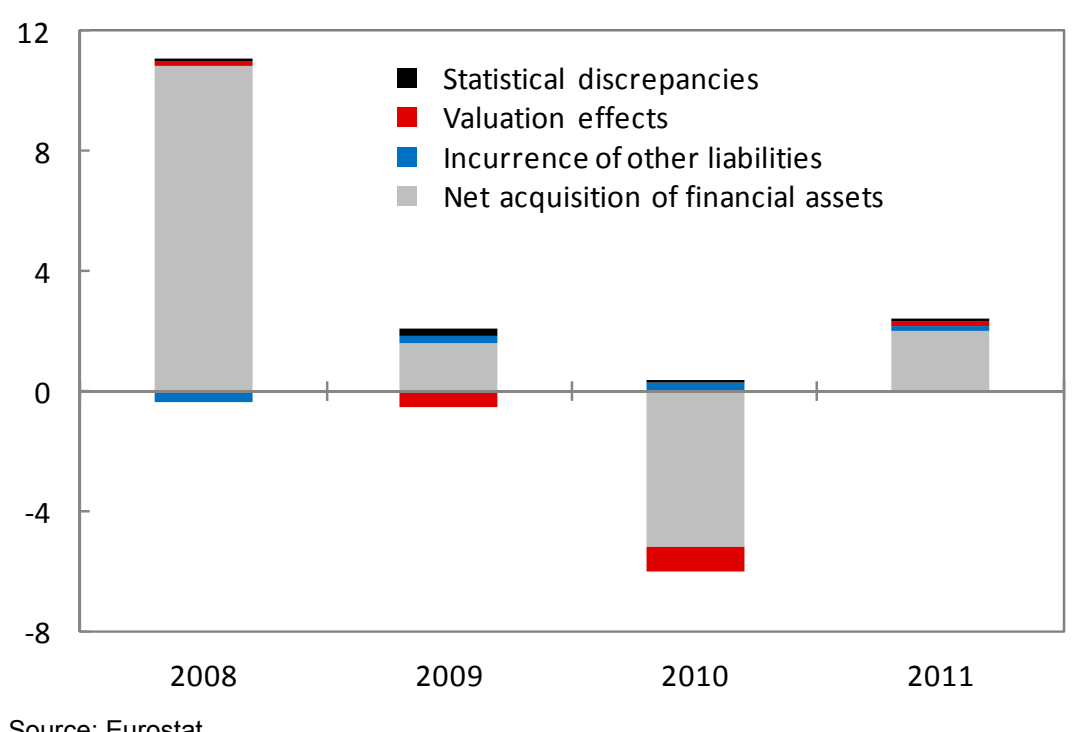

Source: Eurostat

\subsubsection{Historical consistency (Basic)}

21. Ireland discloses revisions to fiscal aggregates in later vintages of published data, and revisions to debt and deficit have generally been in a downward direction. Ireland is required to report EDP-related data to Eurostat twice a year (in April and October) with any update to previously reported data on general government deficit and debt. The CSO has up to four years to provide final data on government deficit and debt figures in relation to first releases of these figures. As shown in Figure 1.7, between 2005 and 2011, Ireland's general government deficit and debt have been revised down by an average of 0.2 and 0.5 percent of GDP respectively. This contrasts with the EU country average where deficits and debts have been revised up by 0.1 and 0.5 percent of GDP respectively for the same period (Figure 1.8). In reporting to Eurostat on revisions to historical fiscal data, the CSO also provides a supplementary table with an item wise breakdown of changes between the old and new time series. However, this supplementary table is not published either domestically or by Eurostat. 
Figure 1.8. Ireland: Size of Historical Fiscal Data Revisions

(Percent of GDP)

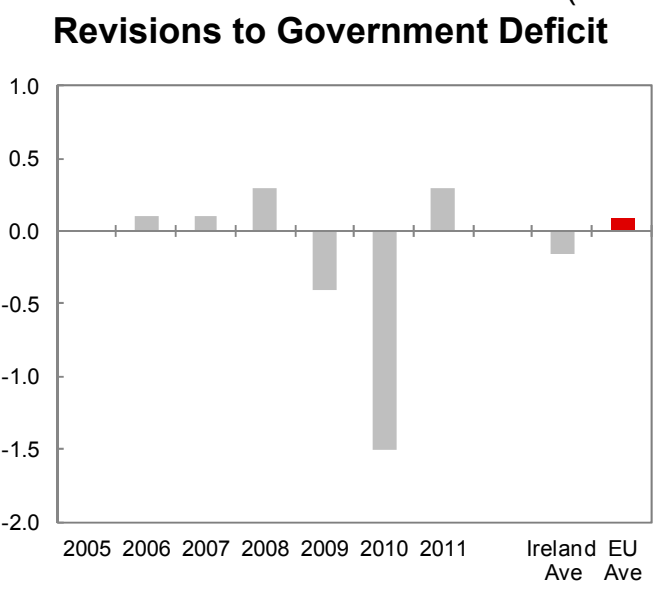

Revisions to Gross Government Debt

Source: Eurostat

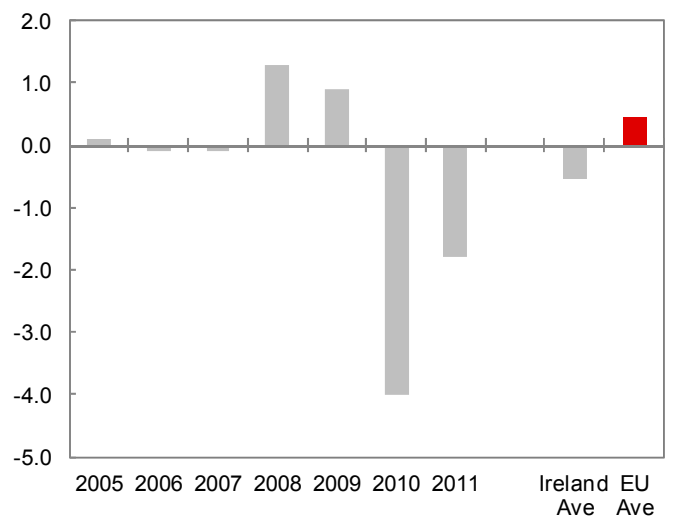

\subsection{Integrity of Fiscal Reports}

\subsubsection{Statistical independence (Advanced)}

22. Fiscal statistics are independently produced and disseminated by the CSO which applies methodology and standards that are harmonized at EU level. The independence of the CSO, which is headed by a Director General and functions under the strategic direction provided by a National Statistics Board, is guaranteed by the 1993 Statistics Act. The CSO has the sole responsibility for the statistical methodologies and professional standards to be followed, the content of statistical releases and publications, and the timing and methods of dissemination of the statistics compiled. It also has the right of access, subject to some conditions, to administrative records held by public authorities for statistical purposes. The methodology used by the CSO for the compilation of statistics is available on its website. As the national statistical institute of Ireland, the CSO is an integral part of the European Statistical System and maintains close contact with Eurostat and the other statistical offices of the EU. Fiscal statistics produced by the CSO are regulated by the principles in the European Statistics Code of Practice, whose purpose is to ensure the quality and credibility of the data. As the responsible agency for production of quality general government statistics under the EDP, the CSO coordinates collection of fiscal data across various institutions and applies the required quality checks.

\subsubsection{External audit (Advanced)}

23. The annual Appropriation and Finance Accounts of the central government and annual financial statements of local governments are audited independently by the C\&AG and the Local Government Audit Service respectively. Under Article 33 of the Irish Constitution, the C\&AG is appointed by the President on nomination of the lower house of Parliament and can only be removed from office for misbehavior or incapacity and following a resolution passed by both houses of Parliament. The C\&AG carries out the audit of both year-end accounts according to the procedures specified under the 1993 Comptroller 
and Auditor General (amendment) Act. The C\&AG conducts financial audit based on International Standards of Supreme Audit Institutions (ISSAI)-compliant standards set for UK and Ireland. The Local Government Audit Service conducts the audit of the local government accounts based on their compliance with the Accounting Code of Practice set by the Department of the Environment, Community and Local Government.

\subsubsection{Reliability (Good)}

24. Ireland's fiscal statistics meet the IMF's Special Data Dissemination Standard (SDDS) and its annual accounts are subject to minor qualifications based on a "properly presents" standard. The CSO produces and publishes government finance statistics data in accordance with the SDDS requirements and it plans to move to SDDS+ in the near future. Upon completion of the audit of annual Appropriation Accounts, the C\&AG attaches to each department's account a certificate stating whether, in his opinion, the accounts properly present the receipts and expenditure related to the Vote concerned, and are prepared in accordance with the accounting rules and procedures laid down by the Minister for Public Expenditure and Reform. In forming the opinion, the overall adequacy of the presentation of the information in the appropriation accounts is evaluated. Some issues related to adequacies of record keeping (e.g., in respect to the Department of Social Protection) have led to minor audit qualifications in recent years. However, since Ireland's government accounts do not follow any internationally recognized standard, the C\&AG is only able to offer a "properly presents" audit opinion, which is also a statutory requirement, as opposed to the "give a true and fair view" audit opinion provided for accounts that follow IFRS or IPSAS. At the local government level, the auditor expresses an opinion as to whether the annual financial statement "presents fairly," in accordance with the Accounting Code of Practice and Regulations, the financial position of the local authority at year-end and its income and expenditure for the year. As there is no practice of preparing central government year-end financial statements and subjecting them to audit, there is no audit opinion on the reliability of consolidated fiscal data.

\subsection{Conclusions}

25. In summary, Ireland's fiscal reporting meets either good or advanced practices in most areas, though the whole is often less than the sum of the individual parts.

Table 1.5 summarizes the quality of Ireland's fiscal reporting relative to the standards set by the Fiscal Transparency Code as well as the relative importance of each area. This assessment highlights a number of areas where reporting can be improved. These include:

- accounts and fiscal statistics limit their coverage to the Exchequer and general government respectively and do not fully reflect the significant financial activity of publicly-controlled corporations;

- summary balance sheet data do not include the government's significant fixed assets, public service pension liabilities, and PPP obligations;

- associated accrual-based flows are also missing from summary fiscal reports and estimates of revenue loss from tax expenditures are incomplete; 
- general government entities use multiple and inconsistent classification systems and charts of accounts which complicates and delays the collection, consolidation, and reporting of the general government fiscal data needed to monitor the government's performance against its national and EU fiscal rules; and

- the timetable for submission and audit of annual financial statements is protracted and does not provide the government with audited outturn figures in time to inform the preparation of the annual budget which will need to be submitted in October starting this year.

Chapter IV includes a series of recommendations for how fiscal reporting can be enhanced in these areas through a combination of consolidating available fiscal information into a new set of more comprehensive summary fiscal reports and automating the collection of additional data through the modernization of underlying government accounting systems. 
Table 1.5. Ireland: Summary Assessment of Fiscal Reporting

\begin{tabular}{|c|c|c|c|c|}
\hline & Principle & Assessment & Importance & $\operatorname{Rec}$ \\
\hline 1.1 & $\begin{array}{l}\text { Coverage of } \\
\text { Institutions }\end{array}$ & $\begin{array}{l}\text { Good: Fiscal statistics } \\
\text { consolidate all general } \\
\text { government institutions }\end{array}$ & $\begin{array}{l}\text { High: Publicly-controlled entities } \\
\text { with net expenditure of } 12 \% \text { of } \\
\text { GDP outside fiscal statistics. }\end{array}$ & 1 \\
\hline 1.2 & $\begin{array}{l}\text { Coverage of } \\
\text { Stocks }\end{array}$ & $\begin{array}{l}\text { Good: Fiscal reports cover all } \\
\text { financial assets and liabilities }\end{array}$ & $\begin{array}{l}\text { High: Public liabilities of } 279 \% \text { of } \\
\text { GDP outside fiscal reports }\end{array}$ & 2 \\
\hline 1.3 & $\begin{array}{l}\text { Coverage of } \\
\text { Flows }\end{array}$ & $\begin{array}{l}\text { Basic: Fiscal reports cover all } \\
\text { cash revenues and expenditures }\end{array}$ & $\begin{array}{l}\text { High: Accrued general government } \\
\text { expenses of } 1.1 \% \text { of GDP outside } \\
\text { fiscal statistics }\end{array}$ & 3 \\
\hline 1.4 & $\begin{array}{c}\text { Tax } \\
\text { Expenditures }\end{array}$ & $\begin{array}{l}\text { Basic: Estimated revenue loss } \\
\text { from income tax expenditures is } \\
\text { published at least annually }\end{array}$ & $\begin{array}{l}\text { Medium: Some of the estimated } \\
6 \% \text { of GDP in revenue lost through } \\
\text { tax expenditures not reported. Tax } \\
\text { expenditures contributed to pre- } \\
\text { crisis property boom }\end{array}$ & 3 \\
\hline 1.5 & $\begin{array}{l}\text { Frequency of } \\
\text { In-year Fiscal } \\
\text { Reports }\end{array}$ & $\begin{array}{l}\text { Advanced: In-year fiscal reports } \\
\text { are published on a monthly basis }\end{array}$ & $\begin{array}{l}\text { Low: Fiscal reports are published } \\
\text { within } 2 \text { days }\end{array}$ & \\
\hline 1.6 & $\begin{array}{l}\text { Timeliness of } \\
\text { Annual } \\
\text { Financial } \\
\text { Statements }\end{array}$ & $\begin{array}{l}\text { Good: Annual financial } \\
\text { statements are published within } \\
9 \text { months of the end of the } \\
\text { financial year }\end{array}$ & $\begin{array}{l}\text { Medium: Audited outturn for the } \\
\text { previous year too late to inform the } \\
\text { preparation of the next year's } \\
\text { budget }\end{array}$ & 5 \\
\hline 1.7 & Classification & $\begin{array}{l}\text { Good: Fiscal reports include an } \\
\text { administrative, economic, and } \\
\text { functional classification } \\
\text { consistent with international } \\
\text { standards }\end{array}$ & $\begin{array}{l}\text { Medium: Lack of a harmonized } \\
\text { chart of accounts across the public } \\
\text { sector delays compilation of fiscal } \\
\text { data for general government }\end{array}$ & 4 \\
\hline 1.8 & $\begin{array}{l}\text { Internal } \\
\text { Consistency }\end{array}$ & $\begin{array}{l}\text { Good: Fiscal reports include two } \\
\text { of the three key flow and stock } \\
\text { reconciliations }\end{array}$ & $\begin{array}{l}\text { Medium: Lack of internal } \\
\text { consistency has resulted in } \\
\text { overstatement of general } \\
\text { government debt by } 2.3 \% \text { of GDP }\end{array}$ & $\begin{array}{l}1 \\
2 \\
3 \\
4\end{array}$ \\
\hline 1.9 & $\begin{array}{l}\text { Historical } \\
\text { Consistency }\end{array}$ & $\begin{array}{l}\text { Basic: Material revisions to } \\
\text { historical fiscal data are reported }\end{array}$ & $\begin{array}{l}\text { Low: Revisions to historical debt } \\
\text { data are }-0.5 \% \text { of GDP on average }\end{array}$ & \\
\hline 1.10 & $\begin{array}{c}\text { Statistical } \\
\text { Independence }\end{array}$ & $\begin{array}{l}\text { Advanced: Statistics are } \\
\text { prepared by an independent } \\
\text { agency which observes } \\
\text { international standards }\end{array}$ & $\begin{array}{l}\text { Low: CSO is subject to Eurostat } \\
\text { governance principles and } \\
\text { statistical standards }\end{array}$ & \\
\hline 1.11 & External Audit & $\begin{array}{l}\text { Advanced: Government } \\
\text { accounts are audited by an } \\
\text { independent supreme audit } \\
\text { institution which observes } \\
\text { international standards }\end{array}$ & $\begin{array}{l}\text { Low: C\&AG independence } \\
\text { protected by the constitution }\end{array}$ & \\
\hline 1.12 & Reliability & $\begin{array}{l}\text { Good: Financial statements are } \\
\text { unqualified and fiscal statistics } \\
\text { meet SDDS+ }\end{array}$ & $\begin{array}{l}\text { Low: Minor qualifications of annual } \\
\text { accounts due to social security } \\
\text { fraud and error }\end{array}$ & \\
\hline
\end{tabular}




\section{FisCAL Forecasting AND BUdGeting}

\subsection{Introduction}

26. In most countries the government's budget is the single most important fiscal document, receiving high levels of public and parliamentary attention. The budget sets out the government's fiscal objectives and policies, demonstrates how those policies will impact the public finances, and seeks the legislature's approval for the proposed levels of taxation and expenditure. It is therefore important that fiscal forecasts and budgets are based on credible forecasts of macroeconomic developments, provide comprehensive information on the government's fiscal objectives and budgetary plans, are presented in a way that facilitates policy analysis and accountability, and are submitted in sufficient time for the parliament to scrutinize and approve them before the budget year begins.

\section{Ireland's budget follows the Westminster tradition, but has been evolving in} line with European requirements over the past two decades. This has led to a gradual evolution away from cash-oriented, Exchequer-focused budgeting set on an annual basis toward setting fiscal objectives for the general government over the medium term. The crisis beginning in 2008 had a severe impact on Ireland's public finances, with revenues collapsing and financial sector interventions placing a heavy burden on the public purse. In response to this, the government has further strengthened the budget process, introducing a new medium-term expenditure framework (MTEF) which includes a set of multi-year expenditure ceilings for each government department, legislating a new suite of fiscal rules and introducing an independent fiscal council.

\section{Further improvements are planned, as Ireland brings its budget process into} line with new EU requirements. The budget documentation will provide clearer linkages between the exchequer and general government fiscal aggregates as new national and EU fiscal rules necessitate management of not only the general government balance and debt but also gross expenditure and revenue. The date of budget submission will be brought forward to meet new European deadlines. More systematic reconciliations of changes to multi-year departmental expenditure ceilings will underpin the credibility of the new MTEF.

\section{This chapter assesses the quality of Ireland's current fiscal forecasting and} budgeting practices relative to standards set by the IMF Fiscal Transparency Code. In doing so, it focuses on four main areas:

i. the comprehensiveness of the budget and associated documentation;

ii. the timeliness of the budget and its passage;

iii. the policy orientation of budget documentation; and

iv. the credibility of the fiscal forecasts and budget proposals. 
Table 2.1. Ireland: Fiscal Forecasting and Budget Documents

\begin{tabular}{|c|c|c|c|}
\hline Document & Purpose & 2012 Timing & 2013 Timing \\
\hline $\begin{array}{l}\text { Stability } \\
\text { Programme } \\
\text { Update }\end{array}$ & $\begin{array}{l}\text { Updates macroeconomic and fiscal forecasts; } \\
\text { sets out fiscal objectives; meets European } \\
\text { requirements. }\end{array}$ & Late April & Late April \\
\hline $\begin{array}{l}\text { Medium-Term } \\
\text { Fiscal Strategy }\end{array}$ & $\begin{array}{l}\text { Updates macroeconomic and fiscal forecasts; } \\
\text { sets out fiscal objectives. }\end{array}$ & Mid-Nov & $\begin{array}{l}\text { Combined } \\
\text { with SPU }\end{array}$ \\
\hline $\begin{array}{l}\text { White Paper on } \\
\text { Receipts and } \\
\text { Expenditure }\end{array}$ & $\begin{array}{l}\text { Provides exchequer fiscal forecasts for the } \\
\text { budget year on a no-policy change basis prior } \\
\text { to the budget }\end{array}$ & Early Dec & $\begin{array}{c}\text { With or } \\
\text { before } \\
\text { Budget } \\
\text { Estimates }\end{array}$ \\
\hline Budget Estimates & $\begin{array}{l}\text { Sets out macro and fiscal forecasts; fiscal } \\
\text { policy; new tax and spending policies; } \\
\text { summary expenditure estimates by vote; } \\
\text { various analytical reports such as distributional } \\
\text { analysis and value for money reviews. }\end{array}$ & Mid-Dec & Mid-Oct \\
\hline $\begin{array}{l}\text { Revised } \\
\text { Estimates }\end{array}$ & $\begin{array}{l}\text { Detailed expenditure estimates by vote, } \\
\text { program objectives and performance indicators }\end{array}$ & End-Feb & Nov \\
\hline Finance Bill & Legislative tax changes & End-Feb & Nov \\
\hline Appropriation Bill & $\begin{array}{l}\text { Formalization of expenditure estimates for the } \\
\text { budget year. }\end{array}$ & $\begin{array}{l}\text { Dec of budget } \\
\text { year }\end{array}$ & $\begin{array}{c}\text { Dec of } \\
\text { budget year }\end{array}$ \\
\hline
\end{tabular}

\subsection{Comprehensiveness of Budget Documentation}

\subsubsection{Budget unity (Basic)}

30. Ireland's annual budget documentation (Table 2.1) still focuses primarily on the cash revenues and expenditures of the Exchequer, though it does include some contextual information about general government fiscal developments. The Finance Bill and Exchequer Estimates voted by the Parliament present the cash flows in and out of the Central Fund, and the financing of those flows. After excluding cash flows from "below the line" financial transactions such as repayment of loans, the Exchequer accounted for 91 percent of the revenue and expenditures of the consolidated central government in 2011. This includes the spending from the Social Insurance and National Training Funds although these are not voted by Parliament. Net expenditure is split between voted (87 percent of Exchequer spending) which is approved annually, and non-voted expenditure (13 percent of Exchequer spending) which includes debt service, EU-related spending, and various capital expenditures, and is appropriated on the basis of standing legislation.

31. There are some fiscally significant central government entities whose revenues and expenditures are not presented in the budget Estimates laid before Parliament. While these 58 extra-budgetary bodies receive 60 percent of their funding in the form of grants from central government departments, their own financed expenditure, which 
accounted for an additional $€ 6.8$ billion (4.3 percent of GDP) in 2011 , is not presented to Parliament in the annual budget estimates. ${ }^{8}$ The most significant of these entities are:

- The National Pension Reserve Fund (NPRF) which was initially established in 2001 to meet the costs of social welfare and public service pensions from 2025 onward, was funded through a combination of windfall revenue from the IPO of the State telecoms company, annual Exchequer contributions of 1 percent of GNP between 2001 and 2007, and income from its investments. However, over the last three years its $€ 16.1$ billion in assets in 2008 have been used to stabilize the financial sector through (its own source) capital injections of $€ 13$ billion (10.1 percent of GDP) into troubled banks. More recently the government has announced that it plans to use some of the NPRF's $€ 6$ billion in non-Irish bank assets to fund investments in strategic industries and small and medium enterprises in Ireland.

- Eligible Liabilities Guarantee Scheme, a temporary fund that was introduced in response to the crisis, guarantees deposits in excess of $€ 100,000$ and is funded through $€ 1.2$ billion ( 0.8 percent of GDP) in guarantee fees, though these are decreasing annually as the scheme is wound down. ${ }^{9}$

- The National Roads Authority, which has responsibility for national roads, is funded primarily through a $€ 1.6$ billion ( 1 percent of GDP) contribution from the Exchequer and $€ 100$ million in toll fees.

- Non-market semi-state bodies, such as Irish Rail and RTE, which operate as commercial enterprises have been classified within the central government boundary.

While the revenues and expenditures of these extra-budgetary entities are not included in the Exchequer Estimates approved by Parliament, their revenue and expenditure are captured in the overall general government fiscal aggregates.

\section{In line with EU requirements, the budget documentation that accompanies the} annual estimates presented to Parliament includes forecasts of the general government fiscal aggregates. In addition to figures for gross general government revenue and expenditure, the SPU and Budget Economic and Fiscal Outlook include a reconciliation (or "walk") from the Exchequer balance to general government balance. However, there is no information provided on how Exchequer revenue and expenditure aggregates (which themselves include a mixture of nonfinancial and financial transactions) relate to the ESA95 general government expenditure and revenue aggregates which form the basis of Ireland's new EU and domestic fiscal rules described in Section 2.3 below.

\footnotetext{
${ }^{8}$ In 2010 this was even higher as a result of the $€ 30$ billion issuance and provision of promissory notes to the IBRC (formerly Anglo Irish Bank/Irish Nationwide) that occurred outside of the Exchequer. In more normal years, the size of self-financed extra-budgetary expenditure by these agencies is around $€ 3-4$ billion.

${ }^{9}$ The Eligible Liabilities Guarantee Scheme is classified as an extra-budgetary entity by the CSO, though it is included in some budget estimates, for instance in the White Paper.
} 


\subsubsection{Gross budgeting (Basic)}

33. The bulk of government revenues and expenditures are presented on a gross basis in budget documentation. All domestic tax revenues and Exchequer expenditures are presented on both a net and gross basis. However, while the spending from non-tax revenues collected by central government departments and agencies (known as "appropriations-inaid") is presented on a gross basis, the budget estimates do not include appropriations-in-aid or social contributions within the revenue estimates. At 7.5 percent of GDP, or 23 percent of revenue, Ireland's non-tax revenues are relatively large as shown in Figure 2.1.

Recognizing the need to provide a clearer picture of the gross Exchequer revenues and expenditures, the government now presents revenue on a gross basis in the revised estimates and in its new Alternative Presentation of the monthly Exchequer Statement. However, this presentation has not yet been extended to the annual budget documentation, making it difficult to compare budgets and outturn for Exchequer receipts.

Figure 2.1. Revenues Retained Outside the Budget (Percent of Gross Expenditure)

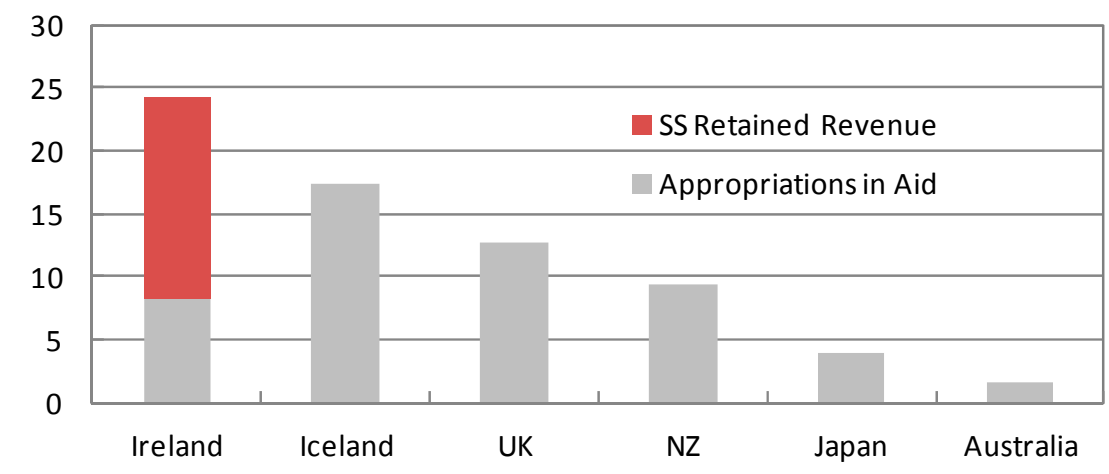

Source: Staff estimates, national budgets.

\subsubsection{Macroeconomic forecasts (Advanced)}

34. Ireland's budget presents the macroeconomic assumptions underlying its fiscal forecasts in a clear, comprehensive fashion. The forecasts are presented in their most comprehensive form in the April Stability Program Update and November Medium-term Fiscal Statement, with the recent outturn and three year-ahead forecasts of key macroeconomic aggregates such as real GDP, the expenditure components of GDP, inflation, the unemployment rate, and GNP. There is a detailed discussion of the forecasts and underlying drivers of each of the components of GDP(E), such as consumption, investment, exports and imports, as well as a discussion around the difference between the GDP and the nationally-relevant GNP measure. The forecasts are then updated in the Economic and Fiscal Outlook which is published alongside the Budget Estimates in December, with any major revisions explained.

\section{Abstracting from the impact of the crisis, Ireland's macroeconomic forecast} errors are relatively large but also are relatively unbiased. Ireland has one of the largest 
absolute forecast errors for GDP amongst the EU, although the major reasons for this are the high degree of volatility in the economy and the large scale of revisions to the GDP estimates (Figure 2.2). Despite this, in the decade leading up to the crisis in 2008, the DoF's macroeconomic forecasts were slightly pessimistic on average and more cautious than most other European economies (Figure 2.3, where each column shows the average forecast error for the budget year, budget year +1 and +2 ), so provided a sound basis for fiscal policymaking, as the errors averaged out over the medium term. The same is largely true for the DoF's forecasts of other key macroeconomic aggregates such as inflation and nominal GDP. Since the crisis, the DoF's macroeconomic forecasts have adjusted quickly to the new state of the world, with relatively realistic assumptions for GDP growth since mid-2011 (Figure 2.4).

Figure 2.2. Average Real GDP Absolute Forecast Errors, 1998-2007 (Percent of GDP)

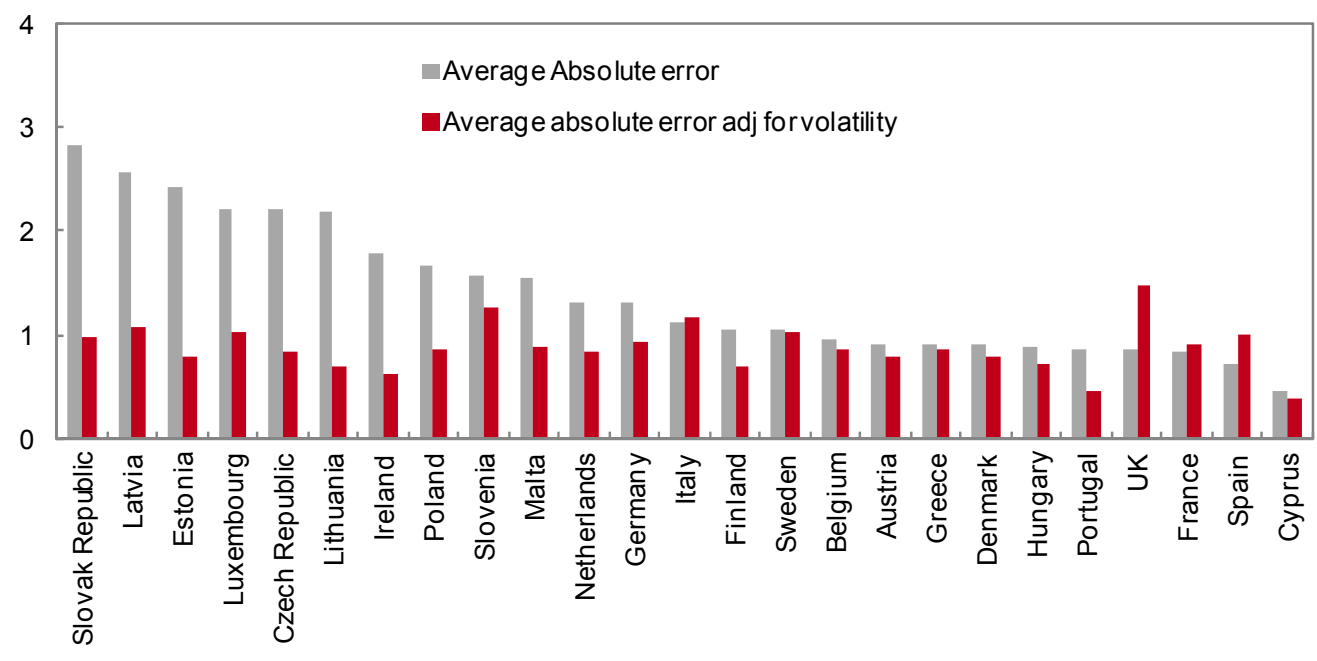

Source: Staff estimates, European Commission.

Figure 2.3. Average Medium-Term Real GDP Forecast Errors, 1998-2007 (Percent of GDP)

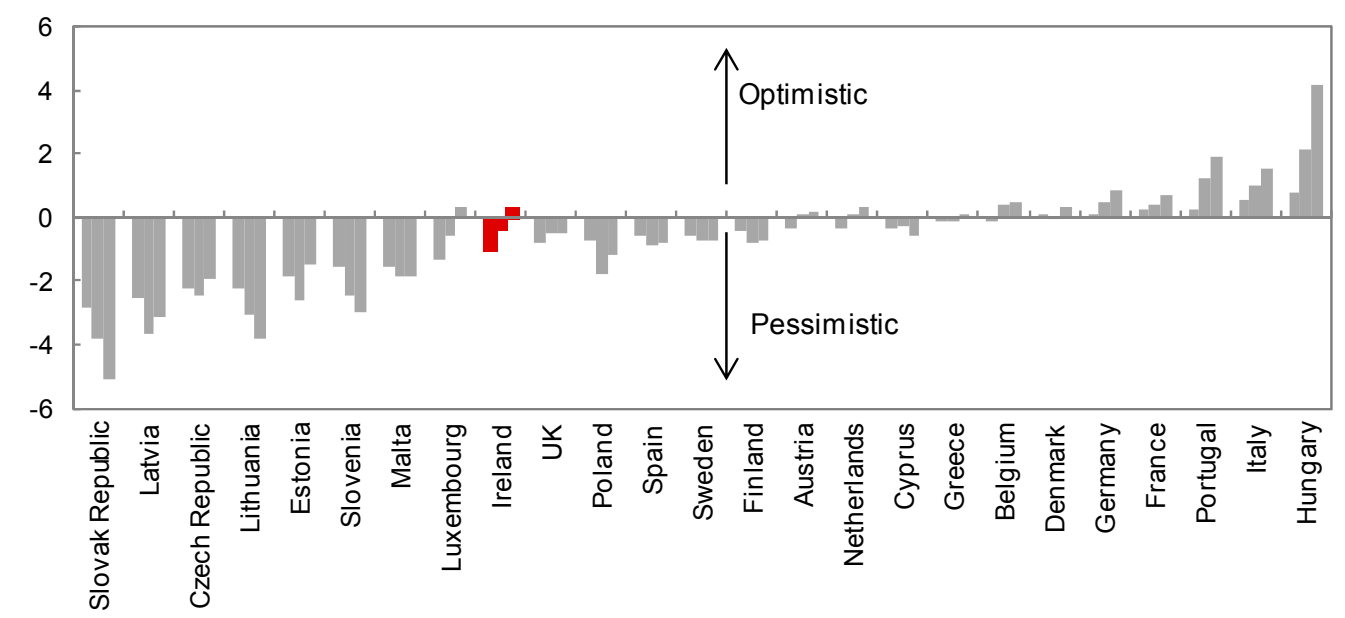

Source: Staff estimates, European Commission. 
Figure 2.4. Real GDP Forecast History

(Constant Euro billions)

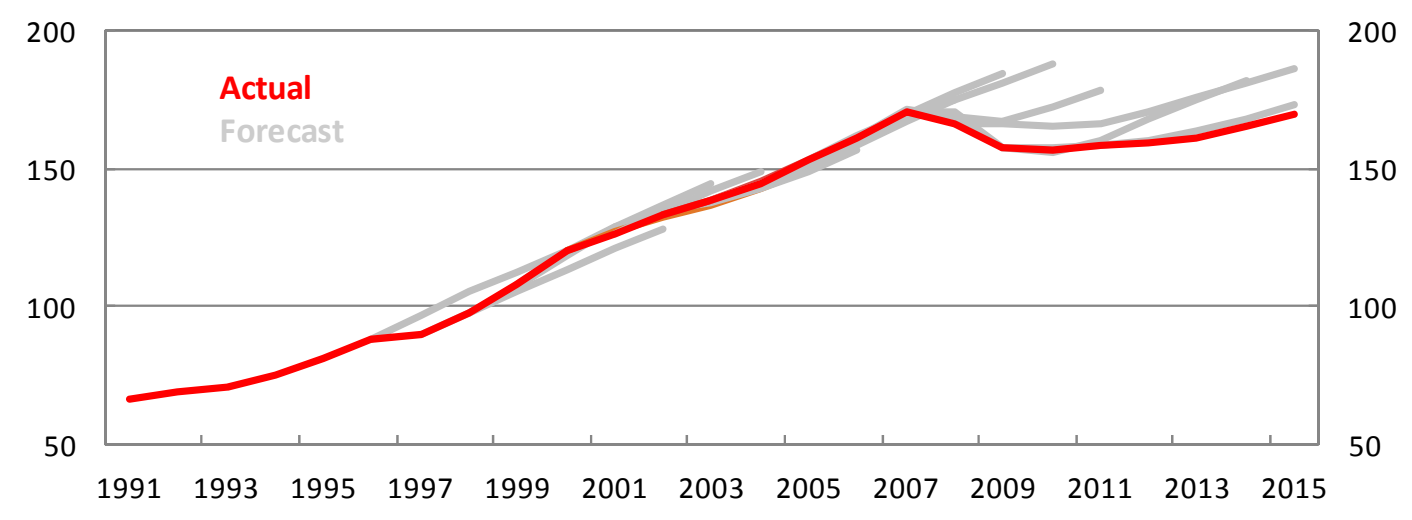

Source: Staff estimates, European Commission.

\subsubsection{Medium-term budget framework (Good)}

36. Ireland's fiscal forecasting record has been relatively cautious in the near-term but mixed over the medium term. Over the pre-crisis period 1998-2007, Ireland's forecasts for general government revenue for the year ahead and over the medium term were relatively conservative, with revenues coming out better than forecast on average. The government tended to adhere to its annual expenditure limits for the year ahead during the period, resulting in larger than expected surpluses against the annual budget forecast (Figure 2.5). At the same time, the pattern of consistent positive surprises on the revenue side led to a gradual upward drift in the expenditure level from one medium-term forecast to the next in the run-up to the crisis. In the immediate aftermath of the crisis, the reduction in economic activity and resulting revenue loss, coupled with the spike in expenditures associated with the government's financial sector interventions saw the actual general government balance fall well short of pre-crisis forecasts as in most other EU countries. However, as with the macroeconomic forecasts, the government's fiscal forecasts have been relatively prudent since 2011 thanks, in part, to more credible medium-term expenditure forecasts. 
Figure 2.5. Average Budget Balance Forecasting Error 1998-2007

(Percent of GDP)

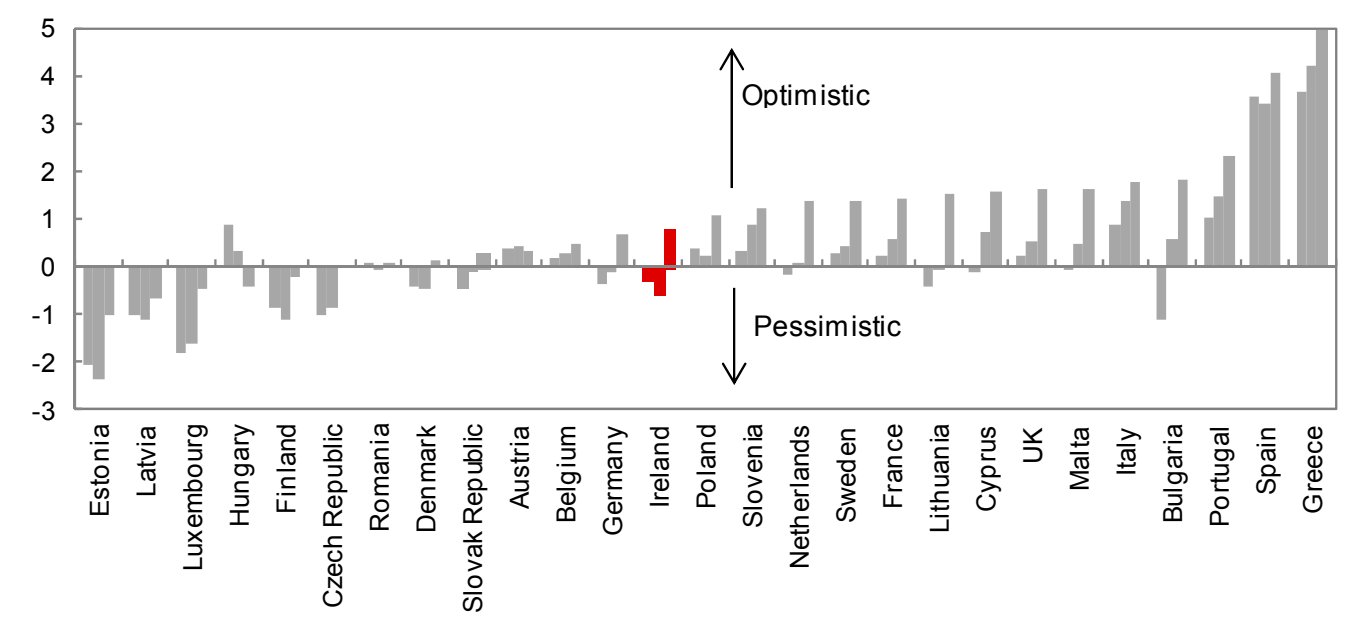

Source: Staff estimates, European Commission.

37. In the wake of the crisis, Ireland introduced a detailed medium-term expenditure framework for central government which appears to have improved multi-year expenditure discipline. Since 2002, Ireland's Stability Program Update has provided three-year forecasts of aggregate general government expenditure and revenue broken down by economic category. Following a Comprehensive Review of Expenditure (CRE) in 2011, the government has also set out net expenditure ceilings for each department or "Vote" on a three-year fixed basis covering 2012, 2013, and 2014. The 2013 Expenditure Report provided a detailed reconciliation of changes to those expenditure ceilings since the CRE, separately identifying the impact of macroeconomic, policy changes, and technical adjustments. As these ceilings were last set in 2011, they currently only extend two years ahead to 2014. However, a second expenditure review is planned for mid-2013 which will set the ceilings for each department for the period 2015-16.

\subsection{Timeliness of Budget Submission and Approval}

\subsubsection{Fiscal strategy report (Advanced)}

38. The government produces a mid-year fiscal report, in the form of the April Stability Program Update (SPU) that sets out the medium-term economic and fiscal parameters for the upcoming budget. Previously, the Medium-Term Fiscal Strategy (MTFS) document, published in October/November provided an update on fiscal developments over the course of the budget year, updated medium-term fiscal and economic forecasts, and presented the revised fiscal targets. The changes in the European semester require the SPU document (which effectively duplicates the MTFS) to be published in April to set the scene for the budget, rather than in January following the budget. Beginning in 2013, the government will only publish the SPU document, rather than duplicating the process in April and November as it did in 2012. In addition to the SPU, the government publishes an updated fiscal forecast in the White Paper on Receipts and Expenditure, which is released in the week prior to the budget, and provides an updated set of fiscal forecasts for 
the upcoming budget year on a no-policy-change basis, providing a benchmark against which all policy changes announced in the budget can be measured.

\subsubsection{Budget submission (Basic)}

39. Ireland's expenditure estimates are submitted to Parliament in early/midDecember, less than a month before the beginning of the financial year, and the Finance Bill, which legislates the tax changes, is not submitted until February. This gives legislators limited opportunity to consider the budget before the start of the financial year to which it refers. Recognizing this, and in line with new requirements under the new EU Six Pack and Two Pack of economic governance regulations, the government plans to bring forward the date of submission of the 2014 Budget to mid-October, which would be sufficient to bring Irish into line with good practice under the Fiscal Transparency Code.

\subsubsection{Budget approval (Not met)}

40. Due in part to their late submission, Ireland's annual expenditure Estimates and Finance Bill are not approved by Parliament until well into the financial year. This is possible because departments have standing authority under the Central Fund (Permanent Provisions) Act, 1965, to spend up to four-fifths of the level authorized for the previous year and because urgent taxation changes can be introduced by way of resolution that has statutory effect for a period of up to four months. The budget approval process is protracted and follows three main stages:

- The first stage occurs in mid-December, when the departmental expenditure Estimates are submitted to the Parliament. It is not necessary for Parliament to approve the expenditure estimates due to the standing spending authority provided under the Central Fund Act. While this arrangement usually works well, it did cause some difficulty in the wake of the crisis when planned expenditure for some departments was below the four-fifths of authorized spending in the previous year for some departments. The Parliament typically approves the Financial Resolutions on budget day to give temporary effect to any indirect tax changes that need to be implemented immediately, subject to confirmation in the Finance Bill.

- The second stage begins in February with the presentation of the Revised Estimates Volume and publication of the Finance Bill in which the government makes what are generally minor updates to departmental estimates and provides more detailed breakdown of their expenditure by program and administrative category. Parliament must vote on the Finance Bill within four months of the Budget, while the Revised Estimates are usually voted on by July which, taken together with the Finance Bill and Social Welfare Act provide the legal authority for central government expenditure and any tax changes in the current year.

- Finally, the Appropriation Bill is submitted and enacted by the Parliament at the end of the budget year (after the submission of the next year's budget in December), formalizing all expenditures that has taken place and adjusting for any amendments that have been taken over the course of the year. 
41. This traditional Westminster approach to budget approval does not meet the basic practice of the Code, and the government is looking at bringing the approval process forward. This will be improved in 2013 and thereafter by the Budget Estimates being submitted in October and by the Revised Estimates Volume being produced and submitted before the beginning of the year to which they refer. This should enable Parliament to approve the estimates either before or shortly after the beginning of the financial year. The approval of the Appropriation Act is still intended to be at the end of the year, as a regularization of the in-year adjustments that are made.

\subsection{Policy Orientation of the Budget}

\subsubsection{Fiscal policy objectives (Good)}

\section{Ireland's fiscal objectives are clearly stated and reported against in its budget}

documentation. Prior to the crisis, the government's fiscal objectives were (i) to meet their obligations under the EU Stability and Growth Pact by aiming for budget balance; (ii) keep the general government fiscal deficit below the 3 percent of GDP limit; and (iii) keep debt below the 60 percent of GDP limit. In the aftermath of the crisis, the government's nearterm fiscal objectives have been set as part of the EU-IMF program and are target a reduction in the general government deficit from 30.9 percent of GDP in 2010, to 8.6 percent in 2012, to 3 percent of GDP by 2015. In line with European requirements, the 2012 Fiscal Responsibility Law introduced a suite of new fiscal rules, including:

- a budget balance rule requiring general government budget balance or surplus; or if in exceptional circumstances, as it is now, a convergence of the structural budget deficit towards the medium-term target of 0.5 percent of GDP;

- a debt rule: when general government debt exceeds 60 percent of GDP, the annual pace of debt reduction must be no less than $1 / 20^{\text {th }}$ of the distance between the actual debt ratio and the 60 percent of GDP limit;

- a medium-term objective of structural budget balance target of no-less than 0.5 percent of GDP; and

- a medium-term expenditure rule, limiting annual growth in general government expenditure to potential GDP growth, as assessed over the past five years, the estimate for the current year, and projections for the next four years.

43. While these rules are precise and time-bound, their number and complexity will require an improvement in the reporting of general government fiscal forecast and outturn in budget documents. The budget documentation should include a section that clearly states each rule, and demonstrates how the budget, as presented on an Exchequer basis, is performing against each of these general government rules, both historically and into the future. In some cases this is already being done, for instance with the fiscal balance rule, where a walk-through from the Exchequer balance to general government balance is provided. However, in other cases, such as the expenditure growth rule, while the budget documentation does give the general government aggregates it does not provide a walk- 
through from Exchequer payments to the general government expenditure. Appendix 1A and 1D provide examples of such a walk through.

\subsubsection{Separation of existing and new policies (Advanced)}

44. The budget documentation distinguishes the cost of existing policies and separately identifies the impact of new policies included in the budget. In the 2013 Budget, these measures are estimated to have increased revenues by 0.9 percent of GDP and reduced expenditures by 1.1 percent of GDP. The impacts of new policy measures on revenue and expenditure are compared against no-policy-change estimates from the White Paper on Receipts and Expenditure that is published in the week before the budget. The budget documentation also factors in the second round effect of consolidation measures on economic activity and tax revenues over the forecast period.

45. Individual policy measures are comprehensively described and quantified, though in a number of different documents. Tax policy measures are set out in the Summary of Budget Measures, which describes each measure and provides the yield/cost for both the budget year and a "full year" cost. Since 2012, expenditure measures are shown in the Estimates as changes to each department's Vote ceiling relative to those set out in the previous year's estimate for both the budget year and a full year.

\subsubsection{Performance information (Good)}

46. Each department's expenditure Estimate includes targets for the outputs to be delivered and retrospective indicators for the outcomes achieved under their Vote, but there is no explicit link to budget allocations within departments. In an appendix to each Departmental Vote, the Revised Estimates includes information on (i) high level policy goals to be pursued by the respective department; (ii) outturn and indicative targets for outputs in numerical terms; and (iii) data on outcome indicators for the last three years. The information on policy-related outputs and impact in the budget documentation has helped to focus the policy debate on department's policy objectives and track their achievement from year to year. However, these policy objectives and nonfinancial performance indicators are not directly linked to the various expenditure programs within departmental Votes, nor are there targets for expected improvements in outcomes against which to compare subsequent department performance. This makes it difficult to understand the connections between departmental goals, objectives, programs, outputs, outcomes, and performance.

\subsubsection{Distributional analysis (Advanced)}

\section{The Irish budget provides detailed distributional analysis of the financial} impact of government policies on citizens. The budget includes an annex describing the impact of the major tax policy changes on household incomes broken down by gross income levels, income sources, and family types, on a pre and post policy change basis. This annex provides a range of illustrative cases of the impact of tax changes on different taxpayer profiles, such as a single person contributing the full rate to PRSI, and a married couple with a single income and two children. There is also some information provided about the 
distribution of tax payers across various groupings, such as the proportion of people exempt from paying PRSI, paying it at the standard rate, and paying at the higher rate.

48. The 2013 budget also draws on external research to demonstrate the progressivity of the cumulative impact of consolidation policies. This research is presented in the Distributional Impacts of Recent Budgets and Progressivity Issues annex, drawing on research prepared by the OECD, ESRI and the European Commission (EC), and demonstrates that high income earners have borne the greatest share of the fiscal adjustment. It also compares the progressivity of the Irish consolidation to six other crisis hit countries, as measured by changes in disposable income levels by income decile due to policy adjustments (Figure 2.6).

Figure 2.6. Example of Distributional Analysis: Percent Change in Disposable Income by Decile Group, 2008-11

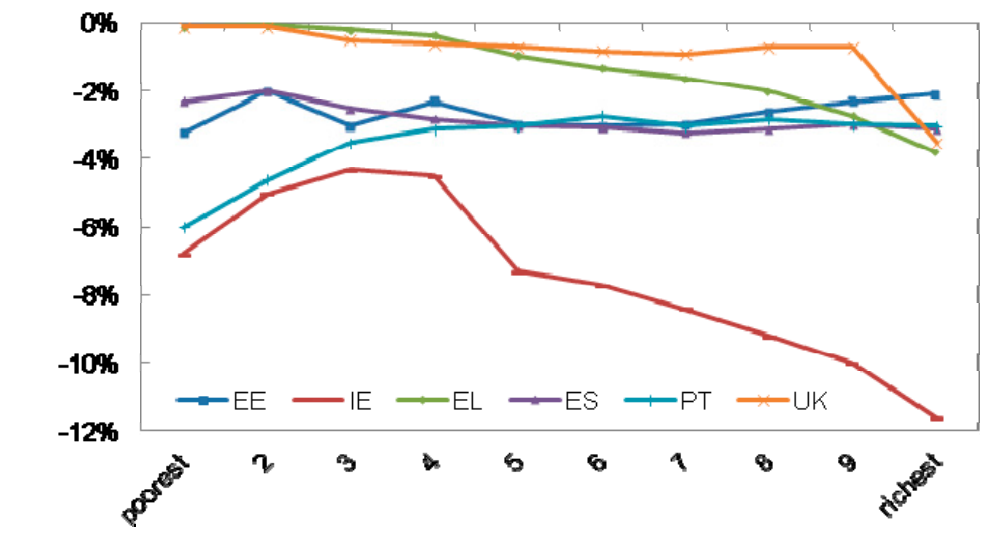

Source: European Commission.

\subsubsection{Fiscal sustainability analysis (Not met)}

49. Ireland's published fiscal forecasts cover a relatively short time horizon and provide limited information about the long-term sustainability of fiscal policy.

The 2013 budget documentation only provided forecasts of the main fiscal aggregates to 2015. The 2012 SPU document provides a summary of the EC's 2009 Aging Report's longterm demographic and spending projections for Ireland out to 2060 which were jointly developed between the EC and Member States. The government has not published a set of long-term projections since the 2007 National Pensions Framework. In addition, the 2013 Expenditure Report includes an analytical chapter on the impact of alternative demographic scenarios on education expenditure between 2013 and 2030. However, in both cases, the analysis is limited to the expenditure side of the budget, and does not assess the implications of these trends for government revenue, balance, or debt. While the DoF has a longer-term forecasting model which it uses to provide inputs into the EC's fiscal sustainability reports, it does not publish its own comprehensive long-term fiscal projections.

50. The lack of comprehensive analysis of Ireland's long-term fiscal stability is of particular concern given Ireland's relatively high levels of government debt and 
growing demographic pressures. Ireland faces a long period of tight fiscal policy in order to bring public debt down from the current level of 118 percent of GDP to the long-term objective of 60 percent of GDP. Demonstrating the compatibility of Ireland's current fiscal policy settings with this objective requires a time horizon of 10 years or more. Ireland's high indebtedness also increases the sensitivity of the main fiscal aggregates to variations in interest and GDP growth rates, increasing the importance of undertaking the kind of scenario-based debt sustainability analysis shown in Figure 2.7. Looking beyond the immediate consolidation, like most advanced economies, Ireland is also facing considerable demographic pressures, which the EC estimates will require an additional 7.4 percent of GDP of expenditure based on existing policies by 2050 .

Figure 2.7. Example of Debt Sustainability Analysis for Ireland
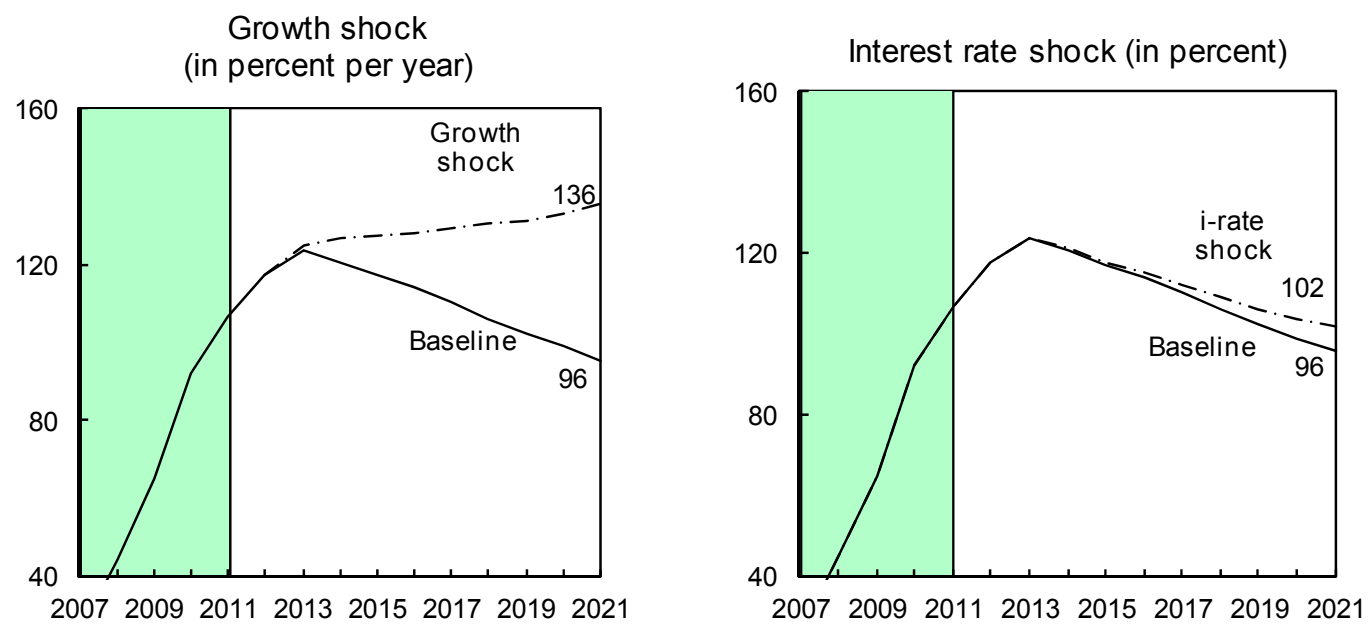

Source: IMF

\subsection{Credibility of Forecasts and Budgets}

\subsubsection{Independent evaluation (Advanced)}

51. Ireland's macroeconomic and fiscal forecasts are evaluated by the independent Irish Fiscal Advisory Council (IFAC). The IFAC was established in 2011 to independently assess and publicly comment on whether the government is meeting its fiscal targets and objectives. It assesses the credibility of the government's macroeconomic and fiscal projections, as well as the appropriateness of its overall fiscal stance. The Council comprises five economists appointed on a part-time basis and a full-time secretariat of three. The members are appointed by the Minister for Finance based on their experience and competence in domestic and international macroeconomic and fiscal matters. IFAC submits its assessment reports twice a year to the Minister for Finance and within ten days of that releases them publicly. If the government does not accept the Council's assessment in relation to the existence or otherwise of exceptional circumstances, non-activation of the correction mechanism in response to significant deviation, or on the progress of a correction against a correction plan, the Minister for Finance must lay a statement before Parliament outlining the government's reasons for not accepting it. 


\subsubsection{Supplementary budget (Advanced)}

52. Any increase in total expenditure or movements between Votes requires approval by Parliament. This approval takes the form of a Supplementary Estimate, which is required whenever (i) additional money is needed for an existing service; (ii) additional funds are needed to cover a shortfall in appropriations in aid (non-tax revenue collected by departments); (iii) to use surplus appropriations in aid to finance additional expenditure; (iv) to transfer appropriation from one departmental Vote to another; or (v) to transfer funds between services within a Vote, when this cannot be done through administrative virements.

53. In practice, the overall expenditure totals set out in the original budget presented to Parliament are respected and reallocations of resources between departmental Votes are limited. As shown in Figure 2.8, Ireland has underspent against Exchequer budget totals in every year since 2004, with an average underspend of 2.3 percent of expenditure. The overall movement of resources between Votes during the budget year averages 0.5 percent of total expenditure, after accounting for the overall underspend.

Figure 2.8. Ireland: Budgeted Expenditure versus Outturn (Percent of GDP)

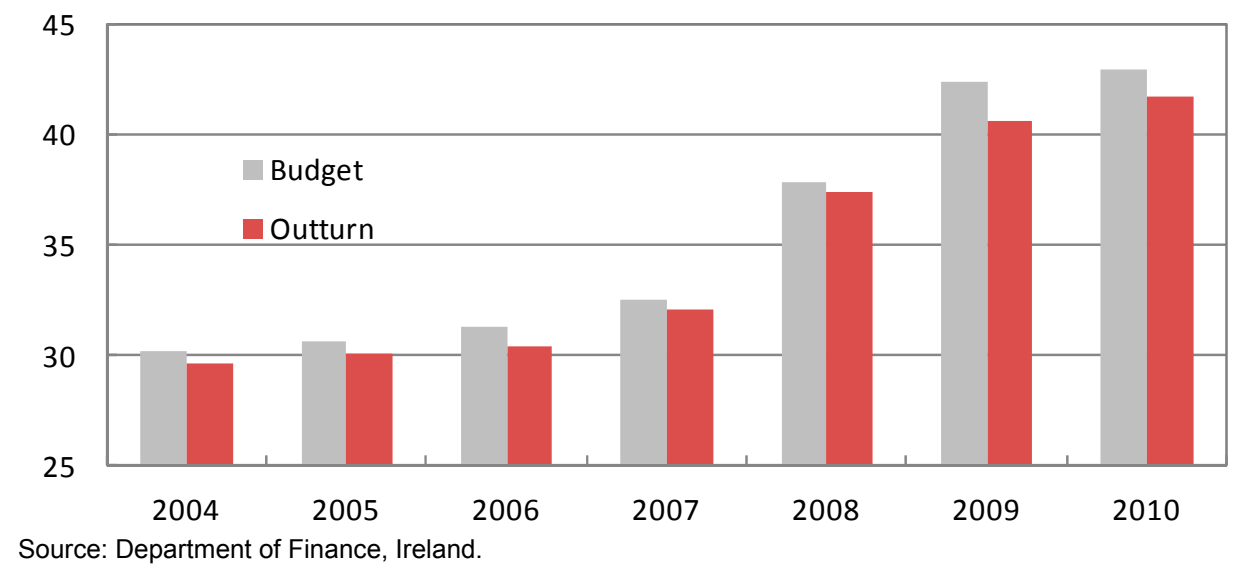

\subsubsection{Forecast reconciliation (Not met)}

54. Ireland's medium-term fiscal forecasts are subject to large variations which are not comprehensively reconciled and explained. The 2013 Budget revised down its tax revenue forecast for 2013 by $€ 835$ million ( 0.5 percent of GDP) and revised up its expenditure forecasts by €2.2 billion (1.4 percent of GDP) compared with the April 2012 SPU-all due to changes in macroeconomic parameters. Such variations then required 2 percent of GDP in policy adjustments to remain within the government's deficit targets. However, this overall picture was not transparently presented and explained in a single publication.

55. Reconciliations are provided for changes in multi-year expenditure allocations between budgets, but not for changes in medium-term projections of revenue or other 
fiscal aggregates. The 2013 Expenditure Report provided, for the first time, a comparison of changes to three-year departmental Vote ceilings since they were announced in 2011. Changes in those expenditure ceilings are broken down into those resulting from macroeconomic factors, policy changes, and technical adjustments. However, the same reconciliation is not provided for changes to broader general government expenditure. Revenue forecasts are only compared to the forecasts prepared in the White Paper on Receipts and Expenditure, which is released a week prior to the budget to provide a baseline against which policy changes can be assessed against. This allows the impact of tax policy measures to be understood in the budget year, but not how this differs from earlier forecasts.

\section{Ireland's new fiscal rules will require the impact of policy measures on general government fiscal aggregates to be more clearly differentiated from parameter variations in medium-term forecasts. Providing such reconciliation will also enable the} IFAC to assess the appropriateness of the government's overall policy response to changing macroeconomic prospects. More transparent reconciliation of the reasons behind changes to expenditure and revenue forecasts will also be critical to demonstrating the government's compliance with the expenditure benchmark, which allows discretionary expenditure increases only where they are offset by discretionary tax increases over the medium term.

\subsection{Conclusions}

57. In summary, the Irish government's fiscal forecasting and budgeting meet either good or advanced practices in most areas, and where practice falls below standard, there are reforms underway to improve disclosure. Table 2.2 summarizes the quality of Irish fiscal forecasting and budgeting practices relative to the standards set by the Fiscal Transparency Code and the relative importance in each area. This assessment highlights a number of areas where forecasting and budgeting can be improved, including:

- the unity and coverage of the budget documentation and legislation, which only cover the Exchequer, leaving out $€ 6.8$ billion (4.3 percent of GDP) of extrabudgetary activity within the central government;

- the timing of budget submission and approval, in which Parliament receives the budget only a few weeks before the beginning of the budget year and approves it halfway into the budget year;

- the relatively short fiscal forecasting horizon and lack of comprehensive fiscal sustainability analysis; and

- the lack of a transparent reconciliation of changes to the main fiscal aggregates between successive fiscal forecasts which makes it difficult to assess the impact of macroeconomic shocks, policy changes, and technical changes on fiscal prospects.

Chapter IV provides a series of recommendations for addressing these gaps in fiscal forecasting and budgeting, both through general improvements in the coverage of fiscal reporting, bringing forward the budget timetable, as well as through improvements in the government's fiscal forecasts and related documentation. 
Table 2.2. Ireland: Summary Assessment of Fiscal Forecasting and Budgeting

\begin{tabular}{|c|c|c|c|c|}
\hline \multicolumn{2}{|r|}{ Principle } & \multirow{2}{*}{$\begin{array}{l}\text { Assessment } \\
\text { Basic: Spending from extra-budgetary } \\
\text { funds, particularly the NPRF, is not } \\
\text { presented in the budget. }\end{array}$} & \multirow{2}{*}{\begin{tabular}{|l|}
\multicolumn{1}{|c|}{ Importance } \\
$\begin{array}{l}\text { High: } € 6.8 \text { bn of } C G \text { spending } \\
\text { outside budget }\end{array}$ \\
\end{tabular}} & \multirow{2}{*}{$\begin{array}{r}\text { Rec } \\
1\end{array}$} \\
\hline 2.1 & Unity & & & \\
\hline 2.2 & $\begin{array}{l}\text { Gross } \\
\text { Budgeting }\end{array}$ & $\begin{array}{l}\text { Basic: Tax revenues and expenditure on } \\
\text { gross basis. Appropriations in aid are not } \\
\text { included in the revenue estimates. }\end{array}$ & $\begin{array}{l}\text { Low: } € 4 \text { bn of } A \text {-in-A are not in } \\
\text { budget revenue, but are } \\
\text { published in monthly statements }\end{array}$ & 1 \\
\hline 2.3 & $\begin{array}{l}\text { Economic } \\
\text { Forecasts }\end{array}$ & $\begin{array}{l}\text { Advanced: Detailed macroeconomic } \\
\text { forecasts are presented and explained }\end{array}$ & $\begin{array}{l}\text { Low: No systematic forecast } \\
\text { bias ( } 0.2 \text { percent cautious bias). }\end{array}$ & \\
\hline 2.4 & $\begin{array}{l}\text { MT Budget } \\
\text { Framework }\end{array}$ & $\begin{array}{l}\text { Good: Fiscal aggregates are presented } \\
\text { over the medium-term, but departmental } \\
\text { breakdown limited to } 2013 \text { and } 2014 \text {. }\end{array}$ & $\begin{array}{l}\text { Medium: } 0.5 \% \text { of GDP of } \\
\text { undefined savings measures } \\
\text { remain to be identified in } 2014 \text {. }\end{array}$ & \\
\hline 2.5 & $\begin{array}{l}\text { Fiscal Strategy } \\
\text { Report }\end{array}$ & $\begin{array}{l}\text { Advanced: Government provides an MT } \\
\text { fiscal strategy report }\end{array}$ & $\begin{array}{l}\text { Low: Regular updates set the } \\
\text { scene for the budget }\end{array}$ & \\
\hline 2.6 & $\begin{array}{c}\text { Budget } \\
\text { Submission }\end{array}$ & $\begin{array}{l}\text { Basic: Budget is provided to the } \\
\text { legislature in the first week of December. }\end{array}$ & $\begin{array}{l}\text { Medium: Less thar } \\
\text { budget debate. }\end{array}$ & 5 \\
\hline 2.7 & $\begin{array}{l}\text { Budget } \\
\text { Approval }\end{array}$ & $\begin{array}{l}\text { Not met: Revised estimates are not } \\
\text { submitted until February and not passed } \\
\text { until June. }\end{array}$ & $\begin{array}{l}\text { Low: Financial Resolutions } \\
\text { allow budget execution to } \\
\text { commence. }\end{array}$ & 5 \\
\hline 2.8 & $\begin{array}{c}\text { Fiscal } \\
\text { Objectives }\end{array}$ & $\begin{array}{l}\text { Good: The government's fiscal objectives } \\
\text { are clearly defined and explained, but } \\
\text { track record needs to be established over } \\
\text { time. }\end{array}$ & $\begin{array}{l}\text { Low: Post-crisis fiscal targets } \\
\text { have been respected to date. }\end{array}$ & \\
\hline 2.9 & $\begin{array}{l}\text { Separation of } \\
\text { Existing and } \\
\text { New Policies }\end{array}$ & $\begin{array}{l}\text { Advanced: All measures are presented } \\
\text { in the budget documentation, with the } \\
\text { impact of policy decisions clearly defined } \\
\text { on the baseline. }\end{array}$ & $\begin{array}{l}\text { Low: New measures are clearly } \\
\text { explained. }\end{array}$ & \\
\hline 2.10 & $\begin{array}{l}\text { Performance } \\
\text { Information }\end{array}$ & $\begin{array}{l}\text { Good: Revised estimates provide } \\
\text { detailed output targets for each vote. }\end{array}$ & $\begin{array}{l}\text { Low: Performance measures } \\
\text { are well defined and outcome } \\
\text { indicators are tracked. }\end{array}$ & \\
\hline 2.11 & $\begin{array}{l}\text { Distributional } \\
\text { Analysis }\end{array}$ & $\begin{array}{l}\text { Advanced: The } 2013 \text { Budget was } \\
\text { accompanied by a detailed assessment } \\
\text { of the impact of policy measures in the } \\
\text { current and previous budgets by income } \\
\text { deciles. }\end{array}$ & $\begin{array}{l}\text { Low: Ireland has the most } \\
\text { progressive consolidation of the } \\
\text { EU crisis countries. }\end{array}$ & \\
\hline 2.12 & $\begin{array}{c}\text { Fiscal } \\
\text { Sustainability } \\
\text { Analysis }\end{array}$ & $\begin{array}{l}\text { Not Met: Long-term fiscal projections are } \\
\text { limited to selected expenditures. }\end{array}$ & $\begin{array}{l}\text { High: Age related pressures } \\
\text { add } 7.4 \% \text { of GDP to } \\
\text { expenditure by } 2050\end{array}$ & 6 \\
\hline 2.13 & $\begin{array}{l}\text { Independent } \\
\text { Evaluation }\end{array}$ & $\begin{array}{l}\text { Advanced: The Independent Fiscal } \\
\text { Advisory Council asses macro and fiscal } \\
\text { forecasts and policies. }\end{array}$ & $\begin{array}{l}\text { Low: IFAC provides two } \\
\text { assessments a year. }\end{array}$ & \\
\hline 2.14 & $\begin{array}{l}\text { Supplementary } \\
\text { Budget }\end{array}$ & $\begin{array}{l}\text { Advanced: Any material increases to } \\
\text { individual votes need to be approved by } \\
\text { the Dail. }\end{array}$ & $\begin{array}{l}\text { Low: Average underspend } \\
\text { against annual budget of } 2.3 \\
\text { percent since } 2004 \text {. }\end{array}$ & \\
\hline 2.15 & $\begin{array}{c}\text { Forecast } \\
\text { Reconciliation }\end{array}$ & $\begin{array}{l}\text { Not Met: Comparisons are provided on } \\
\text { the expenditure side, but not for revenue } \\
\text { or balance. }\end{array}$ & $\begin{array}{l}\text { Medium: } 1.5 \% \text { of GDP upward } \\
\text { expenditure revision }+0.5 \% \\
\text { downward revenue revision. }\end{array}$ & 7 \\
\hline
\end{tabular}




\section{Fiscal Risk ANALYSIS AND MANAgEment}

\subsection{Introduction}

58. Fiscal risks cause fiscal outcomes to differ from forecasts. They include uncertainty about the evolution of fiscally important macroeconomic variables such as growth, inflation, interest rates, and unemployment. They can also arise from specific sources such as calls on government guarantees, tax disputes and other litigation, and changes in the values of the government's assets and liabilities. A government's ability to cope with fiscal risk depends on the quality of its information about risks, its powers to limit its exposure to those risks that can be mitigated, and its capacity to absorb the fiscal consequences of those risks than cannot be mitigated.

59. By many measures, fiscal risks are relatively high in Ireland. Even before the crisis, the government's revenue was volatile by the standard of advanced countries, making fiscal forecasting and management challenging. The rapid rise in general government debt from 25 percent of GDP in 2007 to 118 percent in 2012 leaves Ireland with relatively little room to accommodate further fiscal shocks. At the same time, households, firms, and financial institutions are themselves heavily indebted, increasing the risk that the government will come under further pressure to support other sectors of the economy (Table 3.1).

Table 3.1. Indebtedness and Leverage in Selected Advanced Economies, 2012 (Percent of GDP unless noted)

\begin{tabular}{|c|c|c|c|c|c|c|c|c|c|c|c|c|c|}
\hline & \multicolumn{3}{|c|}{ General government } & \multicolumn{2}{|c|}{ Households } & \multicolumn{2}{|c|}{ Nonfinancial corporates } & \multicolumn{3}{|c|}{ Financial institutions } & \multicolumn{3}{|c|}{ External liabilities } \\
\hline & $\begin{array}{l}\text { Gross } \\
\text { Debt }\end{array}$ & Net Debt & $\begin{array}{l}\text { Primary } \\
\text { Balance }\end{array}$ & $\begin{array}{l}\text { Gross } \\
\text { Debt }\end{array}$ & Net Debt & Gross Debt & $\begin{array}{l}\text { Debt over } \\
\text { Equity } \\
\text { (percent) }\end{array}$ & $\begin{array}{l}\text { Gross } \\
\text { Debt }\end{array}$ & $\begin{array}{l}\text { Bank } \\
\text { Leverage }\end{array}$ & $\begin{array}{l}\text { Bank } \\
\text { Claims on } \\
\text { Public } \\
\text { Sector }\end{array}$ & Gross & Net & $\begin{array}{l}\text { Government } \\
\text { Debt Held } \\
\text { Abroad }\end{array}$ \\
\hline Greece & 171 & n.a. & -1.7 & 69 & -58 & 73 & 235 & 40 & n.a. & 13 & 204 & 96 & 95 \\
\hline Ireland & 118 & 103 & -4.4 & 117 & -74 & 289 & 109 & 706 & 8.3 & 28 & 1,750 & 99 & 71 \\
\hline Italy & 126 & 103 & 2.6 & 51 & -174 & 114 & 138 & 105 & 5.2 & 38 & 146 & 24 & 46 \\
\hline Portugal & 119 & 113 & -0.7 & 104 & -125 & 158 & 154 & 59 & 4.5 & 24 & 285 & 108 & 64 \\
\hline Spain & 91 & 79 & -4.5 & 87 & -74 & 186 & 143 & 115 & 4.9 & 35 & 225 & 92 & 25 \\
\hline Belgium & 99 & 83 & 0.1 & 55 & -202 & 186 & 52 & 123 & n.a. & 24 & 404 & -65 & 57 \\
\hline France & 90 & 84 & -2.2 & 67 & -134 & 134 & 68 & 172 & 2.5 & 18 & 296 & 16 & 58 \\
\hline Germany & 83 & 58 & 1.4 & 58 & -122 & 64 & 96 & 97 & 2.2 & 23 & 219 & -38 & 51 \\
\hline Euro area & 94 & 73 & -0.5 & 71 & -130 & 138 & 107 & 145 & n.a. & n.a. & 194 & 12 & 26 \\
\hline UK & 89 & 84 & -5.6 & 99 & -185 & 116 & 85 & 232 & 4.2 & 8 & 692 & 9 & 28 \\
\hline us & 107 & 84 & -6.5 & 86 & -235 & 89 & 83 & 88 & 7.1 & 8 & 161 & 26 & 32 \\
\hline Canada & 88 & 36 & -3.2 & 91 & -154 & 54 & 44 & 59 & 3.3 & 15 & 103 & 12 & 18 \\
\hline Japan & 237 & 135 & -9.0 & 76 & -241 & 145 & 176 & 188 & 2.8 & 83 & 73 & -57 & 18 \\
\hline
\end{tabular}

Source: IMF, Global Financial Stability Report, October 2012 (Table 2.1) available at http://www.imf.org/external/pubs/ft/gfsr/2012/02/pdf/text.pdf, which provides fuller notes on data and original sources. Note: Cells shaded red, yellow, and green indicate, respectively, values in the riskiest quartile, second-riskiest quartile, and least-risky two quartiles of a larger sample. For Ireland, gross debt of financial institutions and gross external liabilities include the liabilities of large internationally oriented firms that are less important for financial stability than domestically oriented firms (see CBI, Macro-Financial Review, 2012: II, Box 2).

60. As in the area of fiscal reporting, the government publishes much information on fiscal risks, but its value is diminished by being scattered across many documents published by many agencies. Table 3.2 lists documents that include information on fiscal 
risks that were reviewed as part of the assessment. ${ }^{10}$ As well as revealing that the reporting of risk is fragmented, the table shows that much of the information is reported not by the ministries responsible for fiscal management - the Department of Finance and the Department of Public Expenditure and Reform — but by other entities such as the Comptroller and Auditor-General, the Irish Fiscal Advisory Council, and the Central Bank.

Table 3.2. Ireland: Selected Reports Related to Fiscal Risk

\begin{tabular}{|c|c|c|}
\hline Report & Aspect of Fiscal Risk Discussed & Author \\
\hline Medium-Term Fiscal Statement & $\begin{array}{l}\text { Macroeconomic risk, including report on sensitivity of } \\
\text { medium-term forecasts of deficit of general government to } \\
\text { changes in world growth and the savings rate }\end{array}$ & DoF \\
\hline $\begin{array}{l}\text { Economic and Fiscal Outlook in } \\
\text { the Budget document }\end{array}$ & $\begin{array}{l}\text { Brief update on changes in risks since publication of Medium- } \\
\text { Term Fiscal Statement }\end{array}$ & DoF \\
\hline Stability Programme Update & $\begin{array}{l}\text { Effects on deficit of general government of four alternative } \\
\text { scenarios in which GDP grows faster or slower than forecast }\end{array}$ & DoF \\
\hline $\begin{array}{l}\text { Fiscal Assessment Report, } \\
\text { September } 2012\end{array}$ & Fans charts for main fiscal aggregates & IFAC \\
\hline Appropriation Accounts 2011 & $\begin{array}{l}\text { Department-by-department discussion of certain contingent } \\
\text { liabilities; state insurance of land titles }\end{array}$ & DPER \\
\hline Finance Accounts & Government guarantees & DoF \\
\hline National Income and Expenditure & Spending and debt of local and central government & CSO \\
\hline Banking reports & $\begin{array}{l}\text { Risks related to guarantees, ownership of banks, and more } \\
\text { generally exposure to the financial sector }\end{array}$ & DoF \\
\hline Speech, June 7, 2012 & Ireland's callable capital in the European Stability Mechanism & MoF \\
\hline Quarterly Financial Accounts & Assets and liabilities of general government & $\begin{array}{l}\text { CBI, } \\
\text { CSO }\end{array}$ \\
\hline Macro-Financial Review & Financial stability, including the health of the financial sector & $\mathrm{CBI}$ \\
\hline Annual Report and website & Risks related to certain debts and derivatives & NTMA \\
\hline Annual Report & Risks related to certain financial assets & NPRF \\
\hline $\begin{array}{l}\text { Report on the Accounts of the } \\
\text { Public Services, } 2011\end{array}$ & $\begin{array}{l}\text { Interventions in the financial sector; Insurance Compensation } \\
\text { Fund; Deposit Guarantee Scheme; commitments in public- } \\
\text { private partnerships; etc. }\end{array}$ & $C \& A G$ \\
\hline Expenditure Report, 2013 & Contingency reserves & DPER \\
\hline $\begin{array}{l}\text { Local Authority Annual Financial } \\
\text { Statement Outturn }\end{array}$ & Finances of local governments & DECLG \\
\hline Annual reports & Finances and exposure to risk of each public corporation & Various \\
\hline Public Financial Procedures & Various issues related to reporting and management of risk & DPER \\
\hline
\end{tabular}

\section{This chapter assesses the adequacy of Ireland's fiscal risk analysis and management practices relative to the IMF Fiscal Transparency Code in three areas:}

\footnotetext{
${ }^{10}$ The table is not intended to include all reports relevant to fiscal risk. A relevant report that the mission became aware of only after its analysis was completed is the annual report of the Minister of Finance to the Oireachtas on financial support given to credit institution, as required by section 6(15) of the Credit Institutions (Financial Support) Act 2008.
} 
i. general arrangements for disclosure and analysis of macroeconomic and specific fiscal risks;

ii. risks emanating from specific sources such as government assets and liabilities, guarantees, other financial-sector exposures, long-term contracts, and financial derivatives; and

iii. coordination of fiscal decision-making between central government, local governments, and public corporations.

\subsection{Fiscal Risk Analysis}

\subsubsection{Macroeconomic risks (Advanced)}

62. The volatile macroeconomy has been a major source of fiscal risk in Ireland. Even before the crisis, GDP was more volatile in Ireland - and thus, other things equal, harder to forecast - than in other countries of the Euro Area (Figure 3.1.a). The volatility of GDP fed directly into the volatility of the government's revenue (Figure 3.1.b), making fiscal forecasting also difficult. Fast-growing economies are often volatile, but even controlling for growth rates, Ireland's GDP and government revenue were among the most volatile in the Euro Area (Figures 3.1.c and d).

\section{Figure 3.1. Indicators of Macro-fiscal Risk in the Euro Area, 1999-2008}

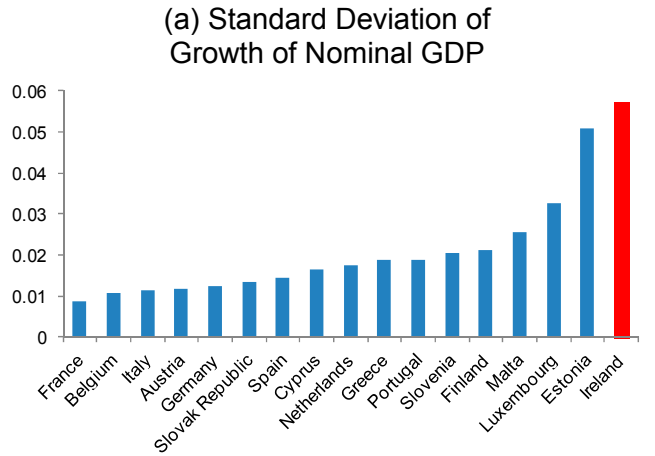

(b) Standard Deviation of Growth of Government Revenue

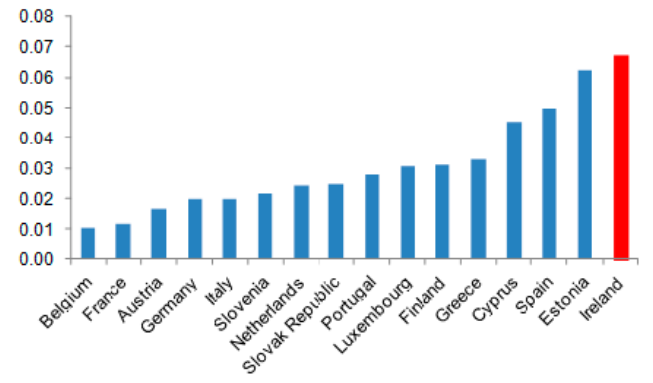

(c) Coefficient of Variation of Growth of Nominal GDP

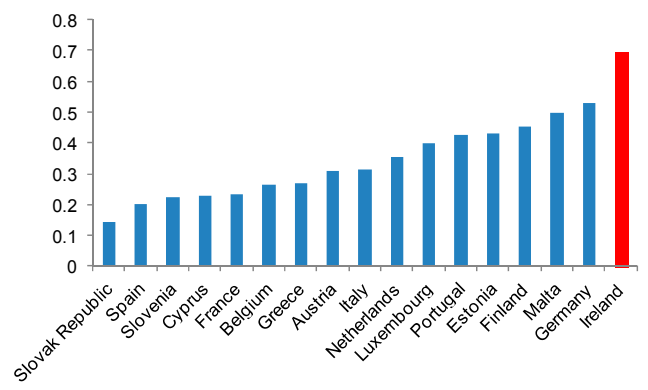

(d) Coefficient of Variation of Growth of Government Revenue

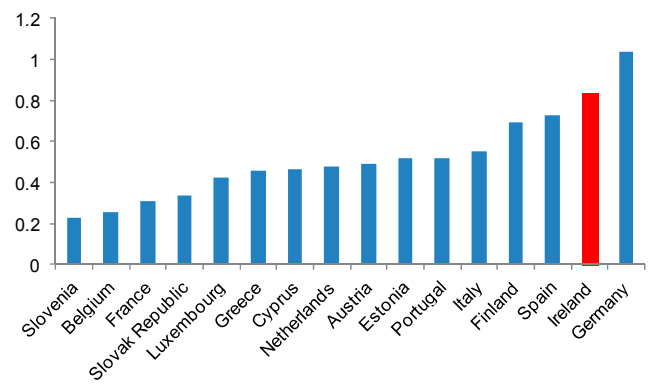

Source: IMF, World Economic Outlook database, October 2012.

Notes: The coefficient of the growth of nominal GDP (for example) is its standard deviation divided by its mean. Government is general government. Malta is excluded from data on revenue because of incomplete data.

63. Three recent reports provide a comprehensive analysis of macroeconomic risks that, considered jointly, meet the standard of advanced practice. These are: 
- the DoF's November 2012 Medium-Term Fiscal Statement which estimates the sensitivity of forecasts of the deficit of general government to changes in world GDP growth and the domestic savings rate;

- the DoF's April 2012 Stability Program Update which projects the deficit of general government under four alternative scenarios (relating to interest rates, world GDP growth, oil prices, and the domestic savings rate) in which growth differs from forecast by 1 percent; and

- the Irish Fiscal Advisory Council's September 2012 Fiscal Assessment Report which, by assuming that the errors in forecasts of nominal GDP will be as large in the future as they have been in the past, presented 80 percent confidence bands for forecasts of debt and deficit of general government until 2015, holding current policy constant (Figure 3.2). ${ }^{11}$

Figure 3.2. Ireland: IFAC's Estimate of Uncertainty Surrounding Future Deficits

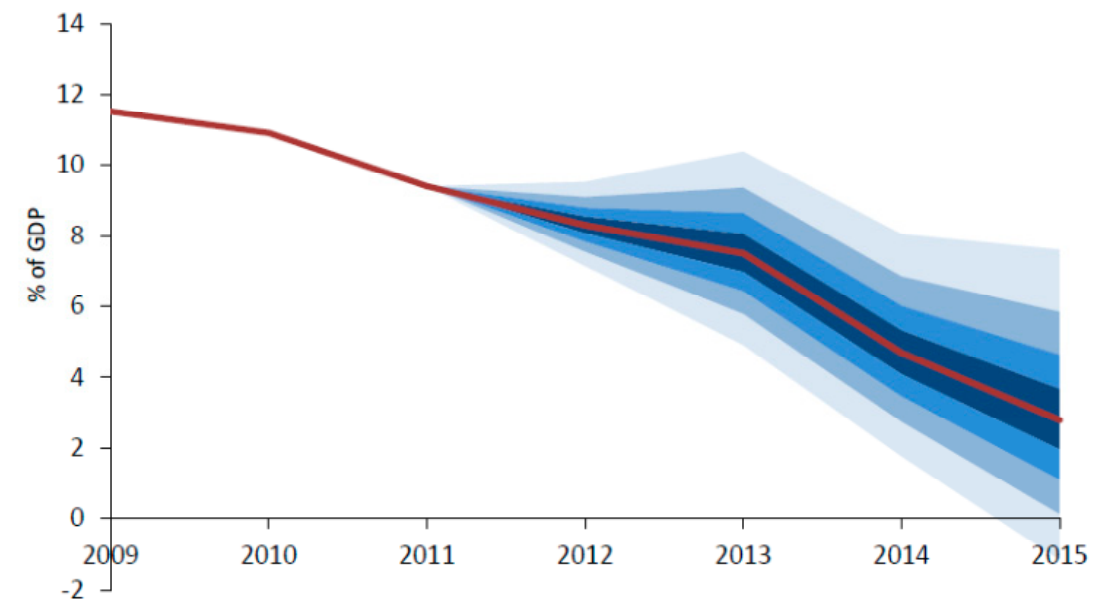

Source: IFAC, Fiscal Assessment Report, September 2012, Figure 3.7a.

Notes: the deficit is for general government. The fan chart shows 80 percent of the probability distribution of outcomes, each band representing 10 percent of the distribution.

\subsubsection{Specific fiscal risks (Basic)}

64. In addition to macroeconomic volatility, the government is exposed to a wide array of fiscal risks arising from sources not easily incorporated in macroeconomic analysis. These "specific" (or "discrete") fiscal risks include:

- factors other than those incorporated in macroeconomic analysis that may cause revenue to be higher or lower than forecast. An example in Ireland is the effect of the

\footnotetext{
${ }^{11}$ See also C. Bermingham and L. Weymes, "Fiscal Compact: Implications for Ireland," Economic Letter Series No. 9, Central Bank of Ireland, 2012.
} 
pharmaceutical "patent cliff" on tax revenue from pharmaceutical firms whose patents are due to expire, which was specifically mentioned in the Economic and Fiscal Outlook and which the government is working to quantify;

- contingent liabilities, including guarantees, deposit insurance, callable capital in international organizations, and law suits (Table 3.3). In some cases, a government's exposure can be quantified, as for example in the case of the guarantees shown in the Finance Accounts. In others, the government's commitment may be open-ended and hard to quantify, as in the case of the Insurance Compensation Scheme. In certain disputes, it may be imprudent to publish an estimate of the amount of a contingent liability because it would affect the government's negotiating position. In addition to these explicit contingent liabilities, there may also be "implicit" contingent liabilities, such as the pressure to stand behind the liabilities of systemically important banks in a financial crisis, even if the liabilities are not guaranteed, or to compensate the victims of a natural disaster, even if the government has no legal obligation to do so;

- risks related to assets and liabilities, including those not currently reported on a balance sheet. Such risks include refinancing risks and the effect of changes in interest rates, exchange rates, and other variables on the values of the government's various assets and liabilities; and

- possible technical changes in the measurement of the debt or deficit that, while not directly changing underlying public finances can affect whether fiscal outcomes are in line with forecasts. An example is the recent reclassification of Irish Rail and RTE into general government and the risk of the reclassification of other public corporations if they fail to operate on a commercial basis.

Table 3.3. Ireland: Selected Contingent Liabilities of General Government, 2011/12

\begin{tabular}{|c|c|c|c|c|}
\hline & $\begin{array}{l}\text { Percent } \\
\text { of GDP }\end{array}$ & $\begin{array}{l}\text { Billion } \\
\text { euros }\end{array}$ & Year & Source \\
\hline \multicolumn{5}{|l|}{ (a) Quantified } \\
\hline Eligible Liabilities Guarantees & 45.0 & 72.8 & 2012 & NTMA website \\
\hline Exceptional Liquidity Assistance & 7.1 & 11.5 & 2011 & Finance Accounts 2011 \\
\hline National Asset Management Agency & 18.0 & 29.1 & 2011 & Finance Accounts 2011 \\
\hline Deposit Guarantee Scheme & 50.7 & 82.0 & 2011 & Comptroller and Auditor General's report 2011 \\
\hline Callable capital in European Financial Stability Facility & 4.6 & 7.5 & 2011 & Finance Accounts, 2011 \\
\hline Callable capital European Stability Mechanism & 6.1 & 9.9 & 2012 & Speech by Minister for Finance, June 7, 2012 \\
\hline Callable capital in European Investment Bank & 1.9 & 3.0 & 2012 & Estimate based on UK's reporting \\
\hline Contingent obligations to other international organizations & 2.4 & 4.0 & 2012 & Estimate based on Australian and New Zealand reporting \\
\hline Other guarantees & 0.0 & 0.1 & 2011 & Finance Accounts, 2011 \\
\hline Credit Guarantee Scheme & 0.0 & 0.0 & 2012 & Website of Department of Jobs, Enterprise \& Innovation \\
\hline Total & 136.0 & 219.8 & & \\
\hline \multicolumn{5}{|l|}{ (b) Unquantified } \\
\hline Insurance Compensation Scheme & & & & Comptroller and Auditor-General's Report \\
\hline Title insurance & & & & Appropriation Accounts \\
\hline Court cases & & & & Appropriation Accounts \\
\hline Revenue guarantees for toll roads & & & & Comptroller and Auditor-General's Report \\
\hline Indemnities, warranties, etc & & & & \\
\hline
\end{tabular}

Source: See table.

Note: The estimates of contingent liabilities related to the European Investment Bank and to other international organizations are based on the named governments' estimates of their own contingent liabilities expressed as a percentage of GDP. The estimates assume that the Irish government's contingent liabilities are the same as a percentage of GDP. 
65. The government does not produce a report on specific fiscal risks, though information on various risks is available in several different reports (Table 3.2). For example, the 2011 report of the Comptroller and Auditor-General, though it is not focused on risk, describes the government's guarantees to the financial sector and its commitments in public-private partnerships. Individual departmental Appropriation Accounts also disclose contingent liabilities associated with particular Votes. For some contingent liabilities, the information in the Accounts is minimal ("the Department is involved in a number of claims involving legal proceedings which may generate liabilities, depending on the outcome of the litigation"). For others, the discussion includes estimates of future spending (e.g., in relation to compensation for child abuse, "additional costs of up to some $€ 150$ million may arise").

66. However, the value of the information is reduced by its fragmentation.

Understanding the universe of fiscal risks in Ireland requires reading more than a dozen reports. To understand only the contingent liabilities shown in Table 3.3, for example, it is necessary to look at the Finance Accounts for government guarantees; the C\&AG's report for information on deposit insurance, the insurance-compensation scheme, and revenue guarantees for tolls roads; various other sources for information on callable capital in international organizations; and the Appropriation Accounts for information on court cases and title insurance. Even within a single document, the information may not be easy to find. For example, because the Appropriation Accounts are prepared for each vote individually but not consolidated, the information on contingent liabilities in the Accounts of 2011 is not summarized in a single table or section but appears on pages $233,318,345,401,424,452$, 468,548 , and 569 .

\subsubsection{Comparability of fiscal reports (Basic)}

\section{Budgets are prepared on the same basis as Exchequer statements, and} differences between the Exchequer balance and national debt, on the one hand, and the deficit and debt of general government, on the other, are explained. As explained in Chapter 1, however, the ESA95 fiscal statistics used to measure compliance with EU fiscal rules are prepared on a basis that is very different from Ireland's budgetary accounting. Moreover, although differences between the two main sets of indicators of the deficit and debt are reconciled, differences in the two measures of spending and revenue are not. Table 3.4 presents such a reconciliation. 


\begin{tabular}{|c|c|c|c|}
\hline & \multicolumn{3}{|c|}{2011} \\
\hline & Revenue & Expenditure & $\overline{\text { Balance }}$ \\
\hline Central Government & 52,410 & 76,174 & $-23,764$ \\
\hline Exchequer (nonfinancial transactions) & 37,576 & 56,223 & $-18,647$ \\
\hline Memo: Exchequer (receipts and issues) & 39,305 & 64,222 & $-24,917$ \\
\hline Appropriations in aid & 4,026 & 4,026 & 0 \\
\hline Social insurance & 9,720 & 9,646 & 74 \\
\hline Other extrabudgetary funds & 4,094 & 7,986 & $-3,892$ \\
\hline Nonmarket semi states & 7,641 & 7,665 & -24 \\
\hline Eliminations within central government & $-11,208$ & $-9,050$ & $-2,158$ \\
\hline Cash-to-accrual adjustments & 562 & -322 & 884 \\
\hline Local Government & 8,294 & 8,284 & 10 \\
\hline Eliminations between LG and CG & $-5,020$ & $-5,020$ & 0 \\
\hline General Government & 55,684 & 77,279 & $-21,595$ \\
\hline Percent of GDP & 35.0 & 48.6 & -13.6 \\
\hline
\end{tabular}

\subsection{Management of Fiscal Risk}

\subsubsection{Contingency reserves (Basic)}

68. Ireland's budget includes small amounts for contingencies. As Figure 2.7 shows, the budget has been underspent in aggregate each year since 2004. To allow for unplanned spending on specific unbudgeted items, the Expenditure Report 2013 includes a line for "contingency expenditure" of $€ 50$ and $€ 70$ million in 2013 and 2014 under current spending (about 0.1 percent of total spending) and an "unallocated reserve" under capital spending of $€ 67$ and $€ 134$ billion in 2015 and 2016 (though nothing for 2013 and 2014). In addition, there is an extra-budgetary contingency fund that was not used in 2011 . It contained $€ 1.2$ million at the end of 2011. The DPER's Public Financial Procedures manual sets out criteria for the use and reporting of the contingency fund (section $\mathrm{C} 1$ ), but there are no published criteria for the use and reporting of the contingency lines in the budget.

\subsubsection{Assets and liabilities (Basic)}

69. The government's holdings of financial assets and, especially, liabilities have increased rapidly in the last decade. As shown in Figure 3.3, on the eve of the crisis at the end of 2007, the government's liabilities amounted to $€ 60$ billion (32 percent of GDP), against which it held $€ 58$ billion in financial assets ( 31 percent of GDP). By the end of the third quarter of 2012, the general government's financial liabilities had more than tripled to $€ 212$ billion (131 percent of GDP) ${ }^{12}$ while its assets had risen to $€ 78.4$ billion (48 percent of

\footnotetext{
${ }^{12}$ This estimate of liabilities is different from the Maastricht measure of debt, because it includes accounts payable and derivatives in loss, which are not counted in the Maastricht measure and because the liabilities are valued at market value instead of at face value. In addition, the reported measure is not fully consolidated. The new data published by the CSO on April 22, 2013 (after the analysis of this report was completed) show total liabilities at the end of 2012 of $€ 207.7$ billion (128 percent of GDP).
} 
GDP). Among the riskier holdings of financial assets are equities of some $€ 23$ billion (14 percent of GDP). As the size of the government's financial balance sheet has grown, large differences have emerged in some years between the deficit and the total change in the government's financial net worth, which depends not only on the transactions that affect the deficit but also on changes in the market values of the government's assets and liabilities. In 2010, for example, when the deficit was 31 percent of GDP, the decline in financial net worth was 22 percent, while in 2011 when the deficit was 13 percent, the decline in financial net worth was 18 percent. ${ }^{13}$ As stressed in Chapter I, the government also has various assets and liabilities not included in the financial balance sheet of Figure 3.3 (see Table 3.5).

Figure 3.3. Ireland: General Government Financial Assets and Liabilities, 2002-12 (Billion Euros)

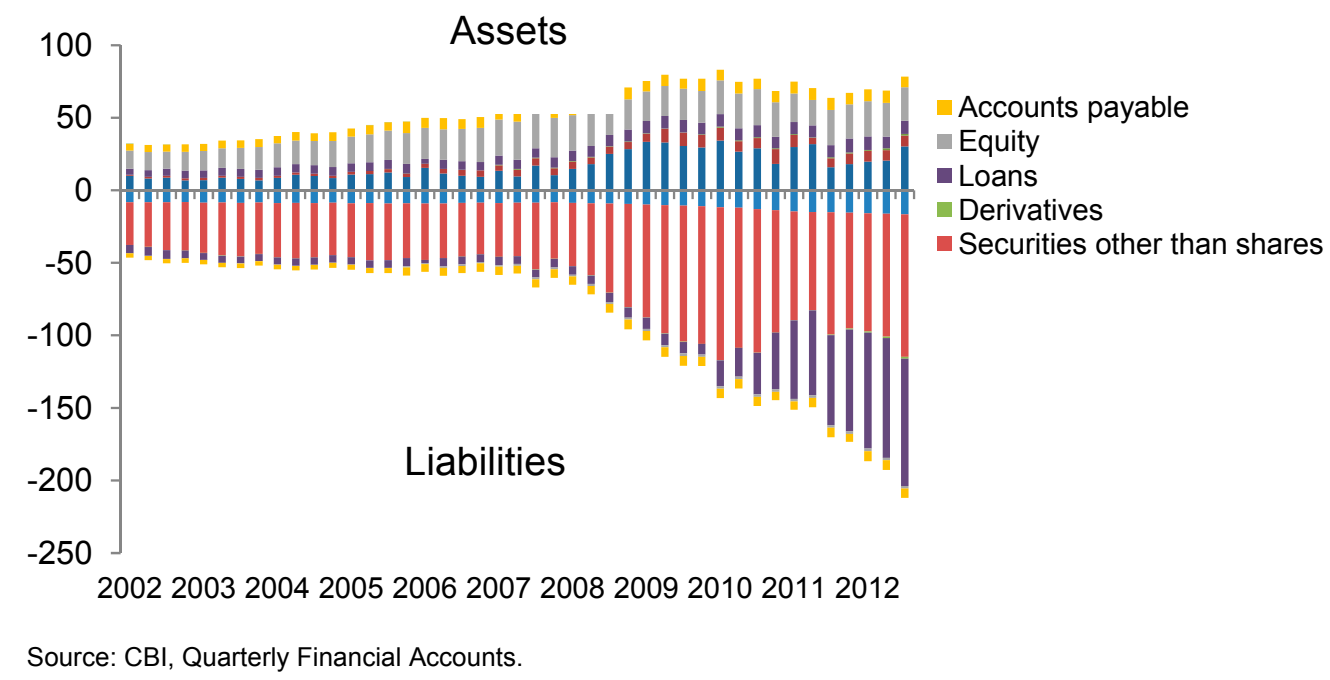

Table 3.5. Ireland: Selected Other Assets and Liabilities, 2011

\begin{tabular}{lcc}
\hline & $\begin{array}{c}\text { Percent of } \\
\text { GDP }\end{array}$ & $\begin{array}{c}\text { Billion } \\
\text { euros }\end{array}$ \\
\hline Assets & $\mathbf{7 4 . 6}$ & $\mathbf{1 1 9}$ \\
Nonfinancial assets & 73.6 & 117 \\
PPPs & 1.0 & 2 \\
Liabilities & $\mathbf{7 4 . 7}$ & $\mathbf{1 1 9}$ \\
Public pensions & 73.0 & 116 \\
PPPs & 1.0 & 2 \\
State Claims & 0.6 & 1 \\
Litigation & 0.1 & 0
\end{tabular}

Sources: CSO; C\&AG; NTMA Appropriation Accounts; IMF staff estimates.

\footnotetext{
${ }^{13}$ This information could be derived from deficit data published by DoF and balance-sheet data published by $\mathrm{CBI}$, but is most easily derived from combined data on stocks and flows published by Eurostat.
} 
70. Government borrowing is generally controlled by the Minister for Finance. As a rule, only the Minister for Finance may borrow (Public Financial Procedures §B3), though the government has delegated primary responsibility for borrowing to the NTMA. Similarly, government agencies need approval to borrow (PFP §C3) and "lease-purchase" arrangements are included in the scope of the restrictions (PFP $\S \mathrm{D} 2)$. Local governments must get approval from the appropriate minister, following a review by the Department of Environment, Community and Local Government of the proposal from a financial viewpoint. Public bodies must also get approval to enter into public-private partnerships, which are arrangements that typically involve commitments similar to borrowing.

71. The NTMA publishes information on risks associated with much of the government's liabilities and describes a strategy for management of financial assets associated with the NPRF. The NTMA's Annual Report for 2011 report provides information on most of the central government's conventional debt. The report covers 79 percent of the liabilities of general government, and while the government's $€ 28$ billion in promissory notes is mentioned, it is excluded from the financial statements. The report also shows the currency composition and maturity profile of the national debt (a measure of net debt), two key indicators of risk, and it discusses refinancing risk in some detail. The report provides summary information on the portfolio of the NPRF, which is managed by the NTMA, and which was worth $€ 13.4$ billion at the end of 2011 (20 percent of the financial assets of general government). A separate annual report for the NPRF discusses the management of risks in this portfolio of assets. Similarly, NAMA's assets and liabilities are also reported. However, there is no report that shows the consolidated assets and liabilities under NTMA's management, analyzes the risks to this portfolio, and describes the strategy for their management.

\subsubsection{Guarantees (Basic)}

72. Government guarantees are an important source of fiscal risk in Ireland, though the government's exposure has fallen sharply since 2009. As they are defined in the Finance Accounts, they have fallen from roughly 200 percent of GDP to 73 percent at the end of 2011 (Figure 3.4). Moreover, roughly half the liabilities the government had guaranteed at end-2011 were liabilities of public corporations and thus cannot be added to the data on the liabilities of the public sector presented in Chapter 1. Nevertheless, guarantees remain large in absolute terms and relative to other EU countries (Figure 3.5). 
Figure 3.4. Ireland: Guaranteed Liabilities, 2008-12

(Percent of GDP)

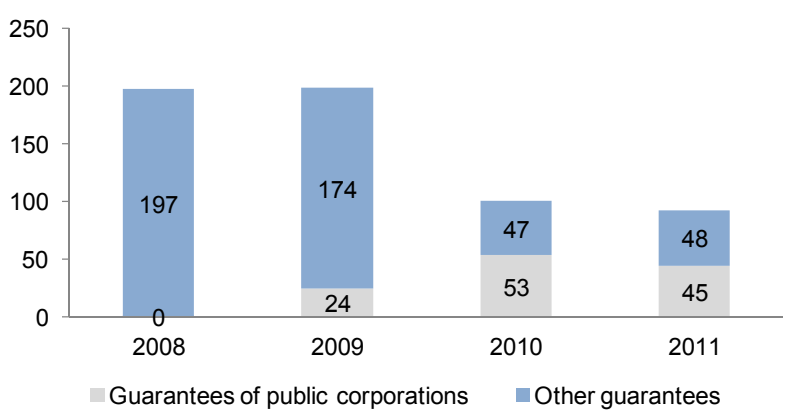

Source: EDP Submission for 2008-2011.

Note: guarantees of public corporations are government guarantees of liabilities issued by corporations (including banks) that are classified in the public sector but not in general government, as reported in the EDP Submission. These guarantees are therefore contingent liabilities of general government but not of the public sector. Other guarantees include some guarantees of the liabilities of general government.

Figure 3.5. Government Guarantees Related to Financial Crisis, Euro Area, 2011 (Percent of GDP)

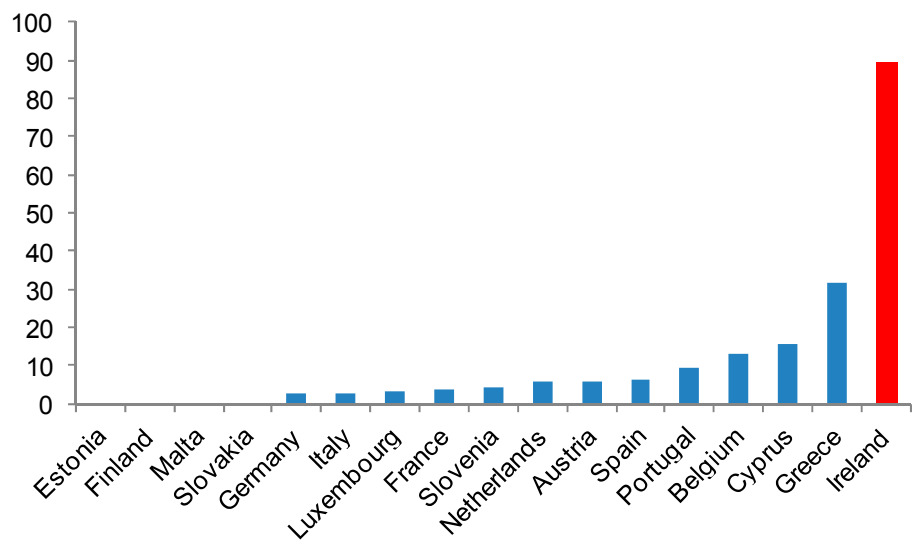

Source: Eurostat, Supplementary Tables for the Financial Crisis, for guarantees; IMF, World Economic Outlook, October 2012, for GDP.

\section{Basic information on government guarantees is disclosed, though issuance} generally remains at the discretion of the Minister for Finance. The 2011 Finance Accounts reported the guarantees shown in Table 3.6. The guarantees, which amount to $€ 147$ billion (92 percent of GDP), were given to a combination of private corporations, public corporations, and general government entities. At the same time, the figures disclosed in the Finance Accounts do not include various commitments that are economically similar to guarantees, even if they have a different legal form. These effective guarantees include the callable capital in international financial institutions, the deposit-insurance scheme covering deposits of up to $€ 100,000$, and the insurance-compensation scheme shown in Table 3.3. While all guarantees have a statutory basis, in some cases there are no prescribed limits on the total amounts guaranteed. 
Table 3.6. Ireland: Government Guarantees, end-2011

\begin{tabular}{|c|c|c|c|c|}
\hline & $\begin{array}{c}\text { Percent of } \\
\text { GDP }\end{array}$ & Billion euros & $\begin{array}{l}\text { Included in } \\
\text { liabilities of } \\
\text { general } \\
\text { government }\end{array}$ & $\begin{array}{l}\text { Included in } \\
\text { liabilities of } \\
\text { public sector }\end{array}$ \\
\hline Eligible Liabilities Guarantees & 63.9 & 101.5 & No & Partly \\
\hline Exceptional Liquidity Assistance & 7.2 & 11.5 & No & Partly \\
\hline National Asset Management Agency & 18.3 & 29.1 & No & Yes \\
\hline Housing Financing Agency & 2.7 & 4.4 & Yes & Yes \\
\hline Other & 0.0 & 0.1 & No & Partly \\
\hline Total & 92.2 & 146.6 & Partly & Partly \\
\hline \multicolumn{5}{|l|}{ Memorandum items } \\
\hline Gurantees, excluding those of liabilities of general government & 89.4 & 142.2 & & \\
\hline Gurantees, excluding those of liabilities of public sector & 44.9 & 71.4 & & \\
\hline
\end{tabular}

Sources: Finance Accounts 2011; EDP Submission to Eurostat, October 2012 (not public) for guarantees of liabilities of public corporations; IMF, World Economic Outlook database, October 2012 for GDP.

\subsubsection{Financial sector exposure (Basic)}

\section{As the crisis has underscored, the fiscal risks emanating from the financial} sector are not limited to those created by explicit government guarantees. A broader measure of the exposure created by the financial sector is given by the sector's total liabilities, guaranteed and unguaranteed. Table 3.1 shows that this measure is extremely high in Ireland compared with other high-income countries, though much of the liabilities are associated with foreign banks that the government is unlikely to come under pressure to stand behind. ${ }^{14}$ Table 3.1 also shows the Irish banks are relatively dependent on the Irish government's creditworthiness, but that their equity as a percentage of their assets, measured at book values, is relatively high. Table 3.7 provides further indicators of the stability of the banking sector in Ireland compared with other European countries and shows a mixed picture. The Tier 1 capital ratio is relatively good, for example, but the ratio of nonperforming loans (NPL) to total loans is high. The CBI's Macro-Financial Review for the second half of 2012 described the situation of the Irish banking sector as remaining "fragile."

\footnotetext{
${ }^{14}$ See CBI, Macro-Financial Review, 2012:II, Box 2.
} 
Table 3.7. Indicators of Banking Financial Stability in Europe, 2012

\begin{tabular}{|c|c|c|c|c|c|c|c|}
\hline & Capital & $\begin{array}{l}\text { Asset } \\
\text { Quality }\end{array}$ & & Funding & & Earnings & $\begin{array}{l}\text { Market } \\
\text { Valuation }\end{array}$ \\
\hline & $\begin{array}{l}\text { Tier } 1 \\
\text { Capital } \\
\text { Ratio, \% }\end{array}$ & $\begin{array}{l}\text { Gross } \\
\text { NPL ratio, } \\
\%\end{array}$ & $\begin{array}{l}\text { Loan-to- } \\
\text { deposit } \\
\text { ratio, \% }\end{array}$ & $\begin{array}{l}\text { Short Term } \\
\text { Funding } \\
\text { Ratio, \% }\end{array}$ & $\begin{array}{l}\text { USD traded } \\
\text { debt as \% of } \\
\text { Wholesale } \\
\text { Funding }\end{array}$ & $\begin{array}{l}\text { Return on } \\
\text { Assets, } \\
\%\end{array}$ & $\begin{array}{l}\text { Price-to- } \\
\text { Book } \\
\text { Ratio }\end{array}$ \\
\hline Greece & 1.5 & 20.2 & 154 & 42 & 3.7 & -0.4 & 0.38 \\
\hline Ireland & 16.2 & 19.1 & 155 & 24 & 1.1 & -0.8 & $\ldots$ \\
\hline Italy & 9.5 & 10.7 & 176 & 25 & 1.5 & 0.4 & 0.32 \\
\hline Portugal & 9.1 & 4.1 & 132 & 18 & 2.4 & 0.3 & 0.37 \\
\hline Spain & 10.5 & 5.6 & 142 & 14 & 5.0 & 0.2 & 0.53 \\
\hline Austria & 9.9 & 8.5 & 119 & 19 & 0.3 & 0.4 & 0.50 \\
\hline France & 11.5 & 5.2 & 116 & 32 & 2.4 & 0.2 & 0.39 \\
\hline Germany & 11.9 & 3.5 & 98 & 10 & 8.7 & 0.2 & 0.79 \\
\hline Netherlands & 14.3 & 2.7 & 99 & 8 & 4.5 & 0.4 & 0.42 \\
\hline UK & 12.6 & 7.5 & 100 & 6 & 10.5 & 0.0 & 0.51 \\
\hline Denmark & 19.7 & 5.8 & 220 & 16 & 0.8 & 0.1 & 0.74 \\
\hline Switzerland & 17.6 & 0.8 & 77 & 4 & 7.1 & 0.2 & 0.69 \\
\hline Sweden & 16.7 & 1.8 & 195 & 9 & 7.3 & 0.6 & 1.22 \\
\hline
\end{tabular}

Source: IMF, Global Financial Stability Report, October 2012 (Table 2.2) available at http://www.imf.org/external/pubs/ft/gfsr/2012/02/pdf/text.pdf, which provides fuller notes on data and original sources. Note: Cells shaded red, yellow, and green indicate, respectively, values in the riskiest quartile, second-riskiest quartile, and leastrisky two quartiles of a larger sample.

\section{Public reports provide basic information on financial-sector risks and the} government's explicit exposure to them. The 2011 report of the C\&AG provides a clear and detailed discussion of the government's interventions in the financial sector. Although it does not attempt to assess the risks faced by the government, it describes the government's guarantees and other factors relevant to an assessment of the risk. The Central Bank's Macro-Financial Review does not discuss fiscal questions, but it analyzes the risks of financial instability, including those emanating from the financial sector. However, the government does not provide its own assessment of potential fiscal risks created by the financial sector.

\subsubsection{Long-term contracts (Basic)}

76. Public-private partnerships are a modest source of fiscal risk in Ireland. The estimated present value of the central government's recorded financial commitments under PPPs given available data was about 2 percent of GDP in 2011 (Figure 3.6). ${ }^{15}$ Not included

\footnotetext{
${ }^{15}$ On April 22, 2013, after the analysis underlying this report was undertaken, the CSO published an estimate of off-balance sheet liabilities related to PPPs in 2011 (and 2012) of $€ 5.049$ billion (3 percent of 2011 GDP). This estimate is higher than the estimate presented in this report and higher even than the undiscounted commitments reported by the C\&AG. The CSO estimate may be too high, because it does not take account of the amortization of the obligations that occurs when availability payments are made, but the government should analyze the underlying data held by DPER and CSO to check the estimates of commitments and the off-balance-sheet liability.
} 
in that estimate, however, are any projected payments in PPPs undertaken by local governments and projected payments by the central government to two toll-road companies that benefit from traffic guarantees. ${ }^{16}$ The government also has certain lease and other commitments. Although PPP commitments in Ireland are not trivial, they are smaller than in Portugal and the United Kingdom, which have two of the largest PPP programs in Europe (Figure 3.6).

Figure 3.6. Estimated Size of PPPs in Ireland, Portugal, and UK (Percent of GDP)

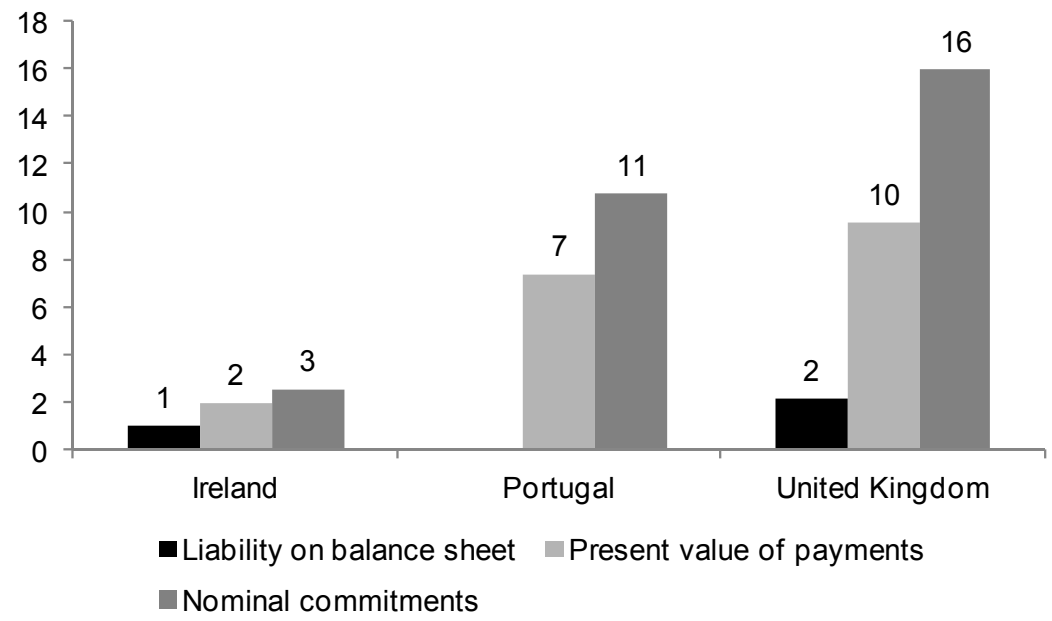

Sources: 2011 C\&AG Report for nominal commitments in Ireland; IMF Staff estimates for present value of payments and liability that would be recognized on the balance sheet under IPSAS, IFRS, or similar standards in relation to government-funded PPP (the available information does not allow for a reliable estimate). Portuguese budget report (Orçamento do Estado para 2012: Relatório) for data underlying estimates of commitments and their present values for Portugal; Whole of Government accounts, 2011, for liability on balance sheet and present value of commitments in the United Kingdom, and H.M. Treasury website for commitments (http://www.hmtreasury.gov.uk/ppp_pfi_stats.htm).

77. The government discloses basic information on its commitments in PPPs. The C\&AG's 2011 report included a substantial section on public-private partnerships, which provided descriptive information as well as information on total government spending on PPPs in 2011 ( $€ 400$ million, or a $1 / 4$ of a percent of GDP) and the above information on the nominal (undiscounted) value of the government's outstanding commitments. Information on PPPs is also available in the accounts of relevant departments and agencies and on the DPER website. ${ }^{17}$ One notable omission is an estimate of how the commitments of $€ 4$ billion are distributed over the remaining years of the contracts - information that is regularly disclosed by the Portuguese and UK governments. ${ }^{18}$ PPP assets and liabilities are also not recorded on the government's accounting balance sheets. While there is no legal limit on the government's ability to enter into PPP contracts, central government departments cannot enter into PPPs without prior authorization from the DPER.

\footnotetext{
${ }^{16}$ See 2011 C\&AG Report, $\S 6.23$ and source note to Figure 6.1.

${ }^{17}$ See http://ppp.gov.ie/files/2012/11/Projects_Sept_12.xls.

${ }^{18}$ See sources to Figure 3.6.
} 


\subsubsection{Financial derivatives (Good)}

78. The government's holdings of derivatives are a potential source of fiscal risks. The net value of the derivatives of general government has been volatile (Figure 3.7), but in the third quarter of 2012 was close to zero (Table 3.5). Another indicator of the possible risks created by derivatives is their notional (or nominal) value, which is the value of the underlying assets or liabilities on which the derivatives are written. The notional value of derivatives managed by NTMA — a subset of the government's portfolio - increased markedly from less than $€ 1$ billion in 2010 to $€ 18$ billion in 2011 (Table 3.8). The true contribution of the risks created, or hedged, by the derivatives, however, cannot be analyzed in isolation from the rest of the government's portfolio of assets and liabilities.

Figure 3.7. Ireland: Net Value of Derivatives of General Government, 2002-12 (Q3) (Billion euros)

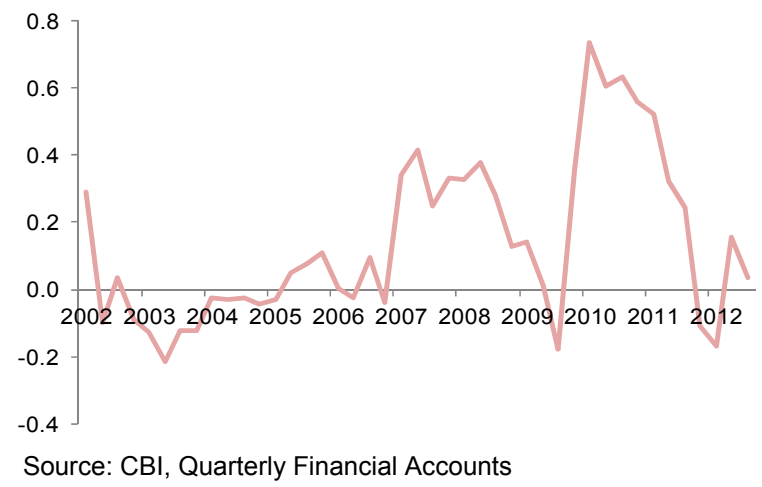

Table 3.8. Ireland: Nominal and Market Values of Derivatives, 2010-12 (Billion euros)

\begin{tabular}{lccc}
\hline & December 31, & December 31, & September 30, \\
& 2010 & 2011 & 2012 \\
\hline General government: Market value & 0.6 & 0.3 & 0.0 \\
General government: Notional value & n.a. & n.a. & n.a. \\
NTMA: Market value & 0.0 & -0.4 & n.a. \\
NTMA: Notional value & 0.8 & 18.0 & n.a. \\
\hline
\end{tabular}

Sources: Central Bank's Quarterly Financial Accounts; NTMA's Annual Report and Accounts, 2011. Notes: Present values reported by NTMA are assumed to be market values. Notional value is also called nominal value.

79. The reporting of the government's derivatives is good. CSO estimates the market value of the general government's derivative assets and derivative liabilities, and the NTMA's annual report discloses the notional values of its derivatives. The reporting would, however, be better if there were a consolidated accounting balance sheet of at least financial assets and liabilities that allowed analysis of the risks of derivatives in the context of the government's portfolio. 


\subsection{Fiscal Coordination}

\subsubsection{Subnational governments (Good)}

\section{Local governments do not appear to be a significant source of fiscal risk in} Ireland owing to their small size and lack of financial autonomy. In 2011, the gross expenditure of Ireland's local governments accounted for just 12 percent of total government spending, much less than in many European countries, as shown in Figure 3.8. Local governments are also highly dependent on grants from central government for that expenditure, with own-source revenues accounting for just 43 percent of their annual expenditure. ${ }^{19}$ At the end of 2011 , the debt of local government was $€ 5.5$ billion, but most of this was owed to central government and the contribution of local governments to the debt of general government was only $€ 1.0$ billion (less than 1 percent of GDP). ${ }^{20}$ While five local governments have (relatively high) debt-to-revenue ratios of 150 percent or more, local governments' borrowing costs are low and no local government has a debt-service-torevenue ratio of more than 7 percent (Figure 3.9). Local authorities also own some businesses that are outside general government, but these are believed to be small.

Figure 3.8. Subnational Government Spending, 2011

(Percent of total general government spending)

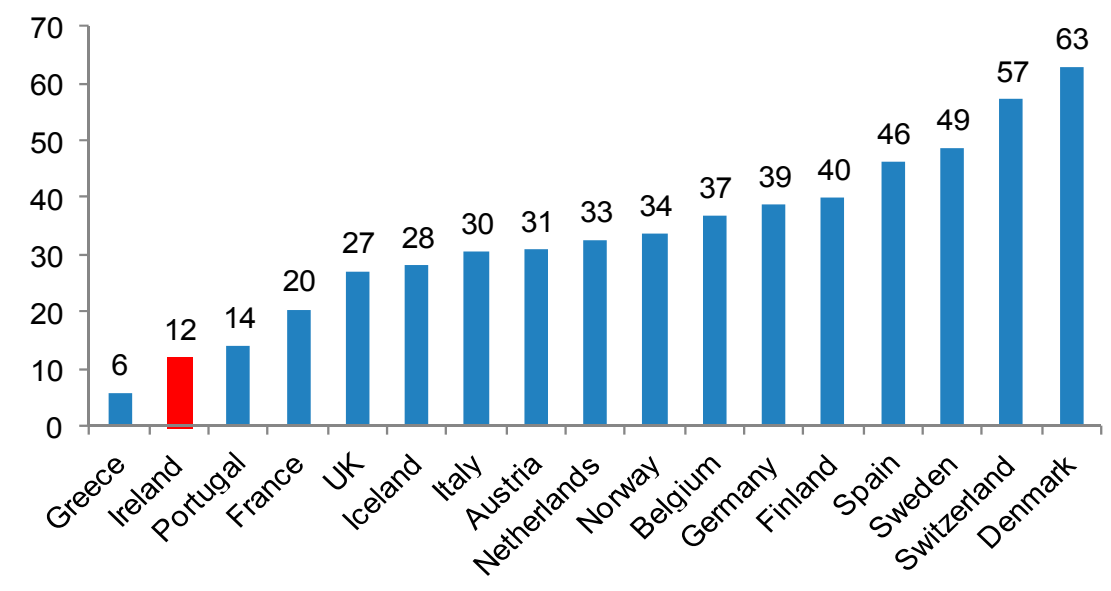

Source: Organization for Economic Cooperation and Development, Fiscal Decentralization database.

\footnotetext{
${ }^{19}$ CSO, National Income and Expenditure, 2011, Table 20. Own revenue is calculated as total receipts less receipts from borrowing less grants from central government.

${ }^{20}$ CSO, National Income and Expenditure, 2011, Table 21(b).
} 
Figure 3.9. Ireland: Local Government Debt and Debt Service to Revenue Ratios

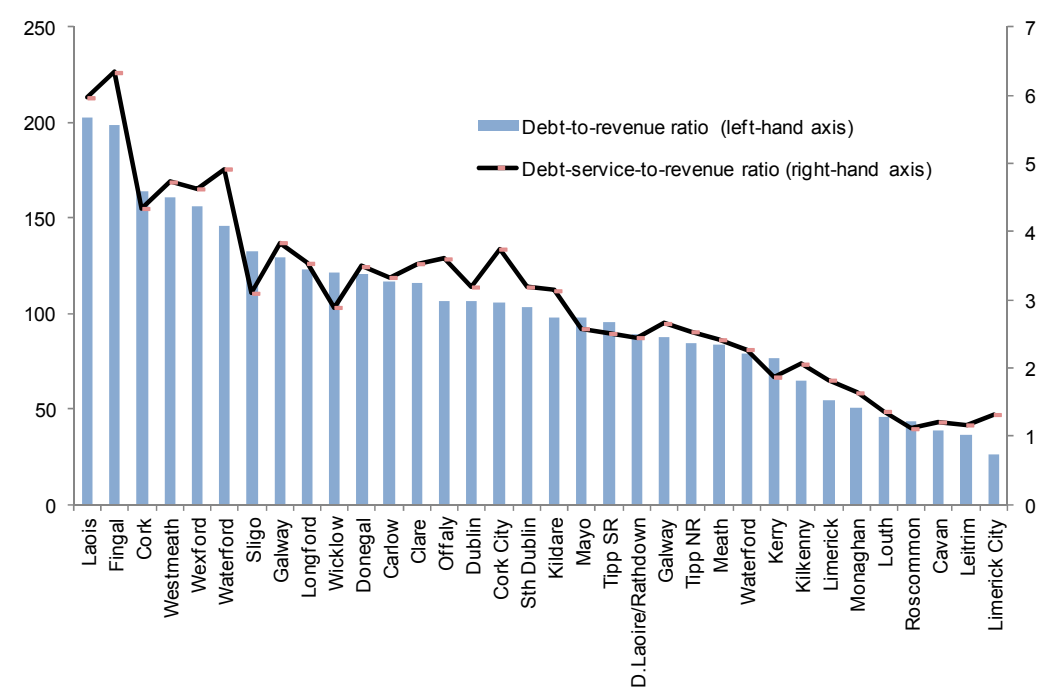

Source: Department of Environment, Community, and Local Government.

Note: Revenue excludes receipts on capital account. Debt includes borrowing from the Housing Finance Agency used for mortgage lending and thus backed by assets.

81. The CSO publishes annual data on the spending, revenue, and debt of local government, and borrowing by local governments is controlled by central government. Although local governments are not subject to numerical limits on their debt, all their borrowing must be approved by the appropriate minister, following a review by the Department of Environment, Community, and Local Government of the proposal from a financial viewpoint. The Department implements a government decision to limit the net lending/net borrowing of the sector (to $€ 200 \mathrm{~m}$ in 2012 , zero in future years). Local governments must also get the approval of the Department to enter into a PPP. Currently lacking but planned by the CSO are published quarterly accounts for local government, which will further improve surveillance of the sector. Also lacking is consolidated information on 240 public corporations controlled by local authorities, which would allow the belief that they pose few risks to be confirmed.

\subsubsection{Public corporations (Basic)}

82. Public corporations, especially public financial corporations, create large fiscal risks in Ireland. As discussed above, the debt of public corporations makes the debt of the public sector about 200 percent of GDP larger than the debt of general government (see Table 1.0 above). By far the largest part of this debt is the debt of financial corporations, including NAMA and Allied Irish Bank (Figure 3.10). To some extent, the fiscal risks associated with public financial corporations are similar to those associated with private financial corporations - any worsening of the financial crisis would put pressure on the government to support systemically important banks irrespective of their ownership. However, with the public banks the government also bears risks related to the value of its equity stakes. The government bears similar risks, on a smaller scale, in relation to its holdings of nonfinancial corporations. 
Figure 3.10. Ireland: Liabilities of Largest Public Corporations, 2011

(Percent of GDP)

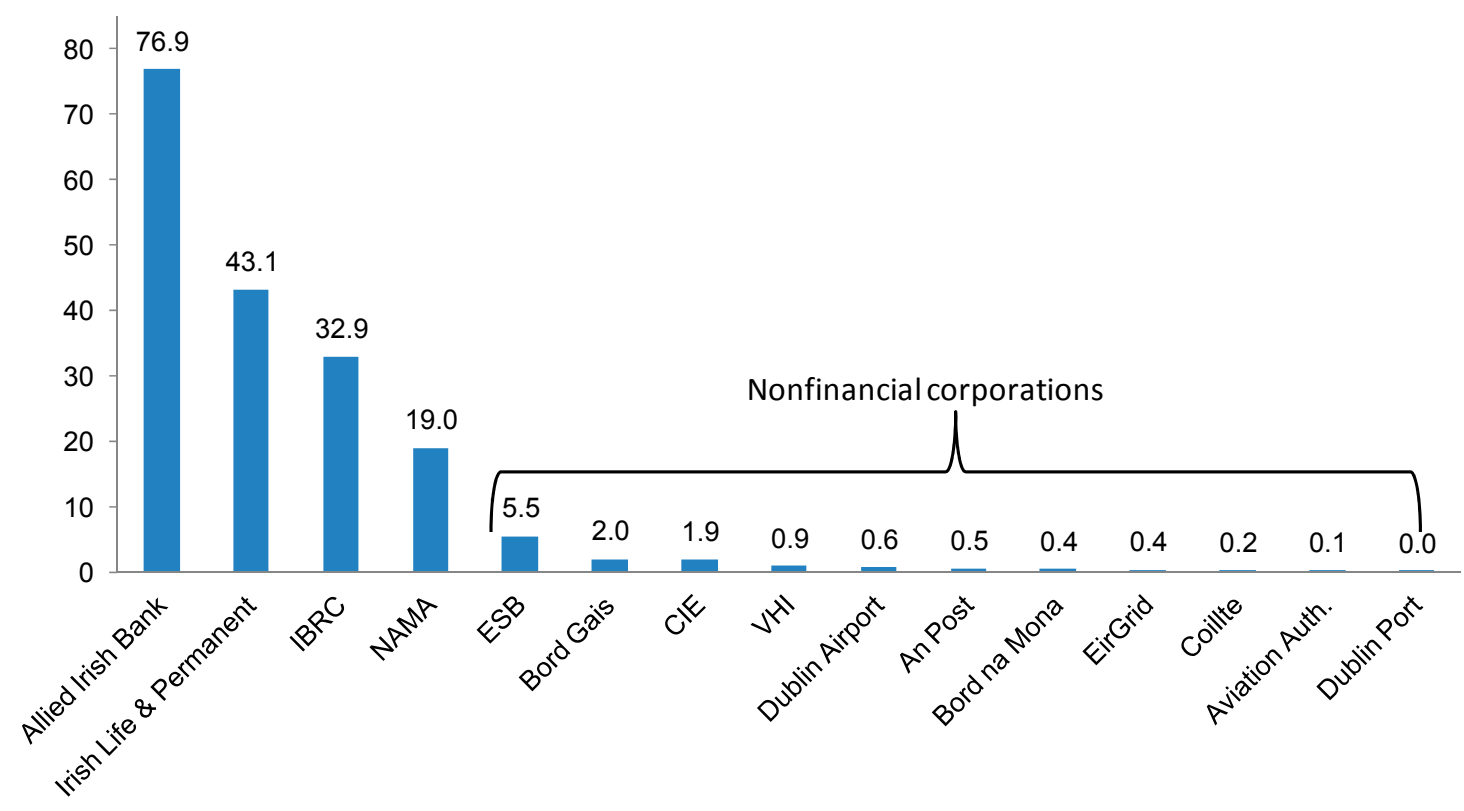

Source: Annual Reports of the corporations.

83. The government publishes basic information on budgetary transfers to public corporations and dividends received from them. Individual corporations also publish their accounts. As well as a lack of consolidated accounts and statistics of the kind described in Chapter I or of the kind of sectoral summary reports produced in France and Sweden, ${ }^{21}$ there is no information on quasifiscal operations of financial corporations. In 2011, the government established the New Economy and Recovery Authority (NewERA) under the auspices of NTMA to provide a perspective on the performance of five large nonfinancial public corporations (ESB, Bord Gáis, EirGrid, Bord na Móna, and Coillte), which creates opportunities for improved oversight and reporting of the finances of public corporations.

\subsection{Conclusions}

84. In summary, the government's reporting and management of risk meets at least basic practice for all principles and in some cases meets the standards of good or advanced practice. Table 3.9 summarizes the quality of Ireland's fiscal risk analysis and management practices relative to the standards set by the Fiscal Transparency Code as well as the relative importance of fiscal risk in each area. This assessment highlights several areas in which fiscal risk analysis and management can and should be improved, including:

\footnotetext{
${ }^{21}$ See http://www.ape.minefi.gouv.fr/ and http://www.government.se/sb/d/2106/a/19792.
} 
- the analysis of and reporting on macroeconomic and specific fiscal risks, which is currently scattered across a number of different documents produced by multiple agencies;

- the disclosure and management of specific fiscal risks arising from government assets, liabilities, contingent liabilities, derivatives, financial sector exposures, and long-term commitments, which meet the basic requirements of disclosure but do not extend to the kind of analysis and can be useful for risk management and mitigation purposes;

- the comparability of fiscal forecast and outturn data where most budget information and in-year fiscal reports is not presented on the same basis as the government's ESA95-based fiscal rules; and

- the oversight of public corporations where new arrangements for improving transparency and enhancing government oversight of the sector are only just being established.

Chapter IV includes a series of recommendations for how these fiscal risks can be addressed both through general improvements in the coverage, quality, and consistency of fiscal reporting practices as well as through the publication of specific documents aimed at enhancing the awareness and management of these risks. 
Table 3.9. Ireland: Summary Assessment of Fiscal Risk Analysis and Management

\begin{tabular}{|c|c|c|c|c|}
\hline & Principle & Assessment & Importance & Rec. \\
\hline 3.1 & $\begin{array}{l}\text { Macroeconomic } \\
\text { Risk }\end{array}$ & $\begin{array}{l}\text { Advanced: Budget } \\
\text { documentation includes } \\
\text { probabilistic forecasts of fiscal } \\
\text { outcomes }\end{array}$ & $\begin{array}{l}\text { Medium: High macroeconomic } \\
\text { volatility makes further } \\
\text { improvements desirable }\end{array}$ & 8 \\
\hline 3.2 & Specific Risks & $\begin{array}{l}\text { Basic: The main specific risks } \\
\text { to the fiscal forecast are } \\
\text { disclosed and discussed in } \\
\text { qualitative terms }\end{array}$ & $\begin{array}{l}\text { High: Many risks are reported, but } \\
\text { the reporting is scattered among a } \\
\text { dozen or more reports }\end{array}$ & 8 \\
\hline 3.3 & $\begin{array}{l}\text { Comparability of } \\
\text { Fiscal Reports }\end{array}$ & $\begin{array}{l}\text { Basic: At least one fiscal report } \\
\text { is prepared on the same basis } \\
\text { as the budget }\end{array}$ & $\begin{array}{l}\text { Medium: Lack of full forecasts and } \\
\text { monthly data for general } \\
\text { government creates problems } \\
\text { monitoring compliance with fiscal } \\
\text { rules }\end{array}$ & $1,2,3,4$ \\
\hline 3.4 & $\begin{array}{l}\text { Contingency } \\
\text { Reserves }\end{array}$ & $\begin{array}{l}\text { Basic: The budget includes a } \\
\text { contingency appropriation }\end{array}$ & $\begin{array}{l}\text { Low: While contingency reserves } \\
\text { are small }(0.1 \% \text { of expenditure), } \\
\text { overspending is limited }\end{array}$ & \\
\hline 3.5 & $\begin{array}{l}\text { Asset and } \\
\text { Liability } \\
\text { Management }\end{array}$ & $\begin{array}{l}\text { Basic: All borrowing is } \\
\text { authorized by law and the risks } \\
\text { surrounding the government's } \\
\text { debt holdings are analyzed and } \\
\text { disclosed }\end{array}$ & $\begin{array}{l}\text { High. General government } \\
\text { liabilities and financial assets of } \\
131 \% \text { and } 48 \% \text { of GDP, plus off- } \\
\text { balance-sheet assets and liabilities } \\
\text { of } 75 \% \text { of GDP each }\end{array}$ & $2,3,8,9$ \\
\hline 3.6 & Guarantees & $\begin{array}{l}\text { Basic: All government } \\
\text { guarantees, and the } \\
\text { beneficiaries and value of each, } \\
\text { are published at least annually }\end{array}$ & $\begin{array}{l}\text { Medium: Explicit guarantees are } \\
\text { large ( } 73 \% \text { of GDP) but have fallen } \\
\text { from } 197 \% \text { in } 2008\end{array}$ & 8 \\
\hline 3.7 & Financial Sector & $\begin{array}{l}\text { Basic: Explicit government } \\
\text { support to the financial sector, } \\
\text { such as deposit insurance, is } \\
\text { quantified and disclosed } \\
\text { annually }\end{array}$ & $\begin{array}{l}\text { High: Risks related to financial } \\
\text { sector remain high }\end{array}$ & 8,9 \\
\hline 3.8 & $\begin{array}{l}\text { Long-Term } \\
\text { Contracts }\end{array}$ & $\begin{array}{l}\text { Basic: The government at least } \\
\text { annually publishes its total } \\
\text { obligations under long-term } \\
\text { contracts }\end{array}$ & $\begin{array}{l}\text { Low. General government PPP } \\
\text { liabilities are only } 1 \% \text { of GDP, } \\
\text { though could increase over time }\end{array}$ & 2 \\
\hline 3.9 & Derivatives & $\begin{array}{l}\text { Good: The government at least } \\
\text { annually discloses its derivative } \\
\text { positions and their notional and } \\
\text { market values }\end{array}$ & $\begin{array}{l}\text { Low. Derivative risks appear } \\
\text { moderate and reasonably well } \\
\text { reported }\end{array}$ & 8,9 \\
\hline 3.10 & $\begin{array}{l}\text { Subnational } \\
\text { Governments }\end{array}$ & $\begin{array}{l}\text { Good: Fiscal condition of } \\
\text { subnational governments is } \\
\text { published annually and there is } \\
\text { a legal limit on the liabilities or } \\
\text { borrowing of subnational } \\
\text { governments }\end{array}$ & $\begin{array}{l}\text { Low. Local governments' debt } \\
\text { contributes less than } 1 \% \text { to general } \\
\text { government debt and their } \\
\text { spending and borrowing is tightly } \\
\text { controlled }\end{array}$ & \\
\hline 3.11 & $\begin{array}{l}\text { Public } \\
\text { Corporations }\end{array}$ & $\begin{array}{l}\text { Basic: All direct transfers } \\
\text { between the government and } \\
\text { public corporations are } \\
\text { disclosed at least annually }\end{array}$ & $\begin{array}{l}\text { High. Incremental liabilities of } \\
\text { public corporations are about } 200 \% \\
\text { of GDP }\end{array}$ & $1,8,9$ \\
\hline
\end{tabular}




\section{RECOMMENDATIONS}

85. Given the already high degree of fiscal disclosure in Ireland, there is considerable scope to enhance further fiscal transparency just by bringing existing fiscal information together, including:

- the DoF's monthly cash-based report on Exchequer revenues, expenditure, and financing which covers 91 percent of general government revenue;

- the CSO's consolidated general government operating statement and financial balance sheet which it submits to Eurostat on a quarterly and annual basis;

- information on fixed and financial assets reported on the balance sheets of central government departments and agencies, local governments, and public corporations;

- estimates of public service pension liabilities, PPP commitments, guarantees and derivatives, contingent liabilities, and tax expenditures from a range of sources;

- forecasts of long-term trends in health and pensions expenditure submitted to the EU for inclusion in their Fiscal Sustainability Report; and

- NTMA, NPRF, and NAMA's analysis of the performance of and risk associated with their holdings of financial assets and liabilities.

86. Reforms in ten key areas could therefore bring Ireland's fiscal reporting practices into line with international standards and best practices at comparatively low cost and within a reasonable timeframe. These are to:

i. expand the institutional coverage of budgets, statistics, and accounts;

ii. recognize a wider range of assets and liabilities in balance sheets;

iii. incorporate the corresponding accrued flows into fiscal reports;

iv. modernize the budget classification and chart of accounts;

v. accelerate the timetable for the submission of the annual budget and accounts;

vi. provide a more detailed reconciliation of changes to fiscal forecasts;

vii. regularly publish long-term fiscal projections;

viii. produce a comprehensive statement of fiscal risks;

ix. publish a medium-term asset and liability management strategy; and

x. harmonize financial reporting standards and practices across the public sector.

87. The actions required to implement these reforms over the next five years are summarized below. By the end of 2017, the ultimate aims of this integrated set of reforms would be to:

- bring the financial activities of all publicly controlled entities into summary fiscal reports; 
- present their operations and balance sheets in a consolidated, integrated, and comprehensive set of financial statements for the public sector and its sub-sectors;

- put Ireland in a position to fully comply with ESA95 and GFSM2001 for fiscal statistics, meet the additional reporting requirements the EU Six Pack and Two Pack and ESA 2010 (summarized in Appendix II), and adopt IPSAS requirements (or their European variant) for government accounting (summarized in Appendix III);

- enable the government to track its performance against its national and EU-wide general government fiscal rules on a monthly basis;

- ensure that fiscal forecasts, budgets, statistics, and accounts are presented on a consistent and comparable basis; and

- enhance public recognition of and government accountability for medium and longterm fiscal developments and risks.

\section{Expand the Institutional Coverage of Fiscal Reports}

88. Issue: 126 central government entities whose net expenditure accounts for $€ 6.8$ billion (4.3 percent of GDP) are currently excluded from the central government budget and accounts. A further 297 entities whose net expenditures accounted for at least $€ 16.8$ billion (11.7 percent of GDP) are outside the scope of the general government fiscal statistics.

89. Recommendation 1: The government should expand the institutional coverage of budgets, fiscal statistics, and financial statements by:

a. expanding the coverage of the annual budget documentation to present the gross revenues and expenditures of the consolidated central government. This will ensure that the annual budget documentation provides the legislature and the public with a comprehensive overview of all tax-funded activities of central government regardless of whether the entity is classified as a vote, extra-budgetary fund, or nonmarket semi-state body (see Appendix1A and 1B);

b. combining the Finance and Appropriation Accounts into a consolidated Central Government Financial Statement. This reform, which may require legislative changes, would provide the Dail, C\&AG, and the public with a comprehensive and accessible summary of the central government's annual financial performance relative to the approved budget (see Appendix 1C);

c. providing an overview of the gross revenues and expenditures of central, local, and general government in budget documentation and in-year fiscal statistics. This will allow for central and local governments to forecast and monitor their performance against the general government expenditure benchmark and other fiscal rules included in Ireland's new FRL and "Six Pack" of new EU regulations and directives (see Appendix 1D); and

d. preparing fiscal statistics for the consolidated public sector and its subsectors. This will provide fiscal policymakers, legislators, markets, and the public with a regular 
and comprehensive overview of the financial position and performance of all publicly controlled entities in the economy (see Appendix 1E).

\section{Recognize a Wider Range of Assets and Liabilities}

90. Issue: Ireland's consolidated government balance sheet data currently excludes the $€ 116.8$ billion ( 73.5 percent of GDP) in fixed assets of central and local governments, the $€ 116$ billion (73.0 percent of GDP) in liabilities associated with public service pensions, $€ 4.0$ billion (2.5 percent of GDP) in liabilities under PPPs, and the $€ 324.7$ billion (204.3 percent of GDP) in assets and liabilities held by public corporations.

\section{Recommendation 2: Recognize a wider range of assets and liabilities in balance} sheets by:

a. revaluing and recognizing accrued pension liabilities of public servants. The 2009 estimate of the present value of accrued pension benefits of serving or retired public servants of $€ 116$ billion needs to be regularly updated and reflected in the central and local government balance sheets;

b. recognizing government assets and liabilities associated with PPPs. The inclusion of these assets and obligations in central and local government balance sheets will provide a more comprehensive overview of their financial position;

c. revaluing and recognizing nonfinancial assets of central government departments. Central government departments already include information on their fixed asset holdings in their annual Appropriation Accounts, albeit some at historic cost and some at replacement cost. Bringing all these valuations up-to-date in line with international standards (subject to a de minimis for small or heritage assets) would enable central government to include a full balance sheet in the aforementioned Central Government Financial Statements (see Appendix 1C); and

d. preparing a financial and full balance sheet for the public sector and its subsectors. Existing data on central government, local government, and public corporation financial assets and liabilities could already be incorporated into a consolidated financial balance sheet for the public sector. Once more up-to-date valuations of fixed assets, pension liabilities, and PPP assets and obligations are available, these could be incorporated into a full balance sheet showing the overall net worth of the public sector as well as general government.

\section{Incorporate Associated Accrued Revenues and Expenses}

92. Issue: Recognition of the above assets and liabilities in balance sheets allows for the incorporation of the related, fiscally significant, flows in summary fiscal reports. At present these unrecognized expenses could amount to 1 percent of GDP per year.

\section{Recommendation 3: Incorporate the corresponding economic flows in fiscal documentation by:}

a. reflecting changes in accrued public sector pension liabilities in budget documentation, statistics, and accounts. Once an estimate of the present value of 
public sector pension liabilities is included in the central and local government balance sheets, changes in that valuation, which amounted to approximately $€ 1$ billion, can be incorporated as a non-cash flow in central government revenues and expenditures;

b. incorporating information on the annual flow of government investments and payments under PPPs into fiscal projections, budgets, and accounts. ${ }^{22}$ The inclusion of this information in annual, medium-term, and long-term fiscal projections will help to demonstrate the long-term affordability of these commitments;

c. utilizing department-specific depreciation figures in summary statistics and accounts. Fiscal statistics and fiscal forecasts currently use an economic measure of depreciation, based on the perpetual inventory model, which is $€ 1.8$ billion higher than the sum of depreciation figures reflected in the accounts of central and local government departments. Updating the valuation of fixed assets in central government department and local government accounts would allow the latter, more accurate, measure to be used in all three fiscal documents;

d. recognizing valuation changes in public sector assets, liabilities, and contingent liabilities in fiscal documentation. Once a comprehensive balance sheet for the public sector is prepared, changes in the value of the assets, liabilities, and contingent liabilities can be recognized in the relevant sub-sector accounts and as a supplementary disclosure in budgets. This will ensure consistent and integrated set of financial statements for all sub-sectors; and

e. providing a more comprehensive estimate of revenue foregone from all tax expenditures. Annual estimates of the cost of tax expenditures should be extended beyond revenue foregone on income and corporation taxes to fully cover the estimated 6 percent of GDP in total revenue foregone from all direct and indirect tax allowances, reliefs, deductions, and rebates in a manner which does not add to the compliance burden on taxpayers.

\section{Modernize the Budget and Accounting Classification}

94. Issue: The charts of accounts for central government departments, extra-budgetary funds and other non-market agencies, local governments, and public corporations are not able to automatically generate summary fiscal data in line with international reporting standards. This poses a significant obstacle to the preparation of more comprehensive, detailed, and comparable fiscal reports. It also inhibits real-time monitoring of Ireland's fiscal performance against its national and EU-wide fiscal rules which are defined in general government terms.

\footnotetext{
${ }^{22}$ This would mean producing a measure of public spending that recorded privately financed investment in PPPs as public investment at the time the investment occurred and also recording the investment and a corresponding liability on the government's balance sheet. Investment in PPPs and investment in traditional publicly financed investments would thus have similar effects on the government's accounts.
} 
95. Recommendation 4: Bring the classification of fiscal documentation into line with international standards by:

a. reorganizing the monthly Exchequer Statement to present gross revenues and expenditures and distinguish nonfinancial and financial transactions. This would supplement the current Exchequer Statement and bring its classification closer to the ESA 95 and GFSM 2001 presentation (Appendix 1F and 1G);

b. develop an exhaustive program classification which can be mapped to both individual output/impact indicators and COFOG sectors. This would enhance departmental accountability to parliament for the use of public resources and automate the presentation of international comparable statistics on the functional allocation of government expenditure; and

c. develop a harmonized chart of accounts for all general government and, eventually, public sector entities. This would facilitate the automated collection and consolidation of detailed fiscal data for the central government, general government, and public sector. Such a standardized chart of accounts should produce summary fiscal data in line with international standards while also allowing entities the flexibility to generate fiscal data for internal management reporting. The planned shared services project, which has a financial management component, presents an opportunity to rollout such a harmonized chart of accounts across central and local governments.

\section{Bring Forward the Timetable for Budgeting, Accounting, and Audit}

96. Issue: The government's audited accounts are currently published too late to inform the preparation of the annual budget. The annual budget estimates are submitted too late for parliament to debate and approve them before the start of the year to which they refer.

97. Recommendation 5: Accelerate the production, presentation, and approval of the annual budget and accounts in line with current plans by:

a. requiring the government to submit the annual budget to parliament in October. This would bring Ireland's budget timetable into line with the Common Budgetary Timeline set out in the EU Two Pack Regulation concerning the monitoring of draft budgetary plans which requires member states to publish their draft central and local government budgets by October 15;

b. requiring parliament to approve the annual budget in December. This would give parliament at least two months to scrutinize the draft budget while ensuring that all public entities have an approved basis on which to execute their financial operations from January 1. It would also meet the EU Two Pack requirement that central and local government budgets be adopted by December 31;

c. requiring the government to submit its annual accounts to the $C \& A G$ by March or an agreed earlier date. This would allow outturn data from the previous year's accounts to inform the preparation of the Stability Program Update which needs to be submitted to the EU by end-April and provides the framework for the preparation of next year's budget; and 
d. requiring the $C \& A G$ to submit the audited accounts to parliament by June. This would ensure that the annual budget for the next year is prepared on the basis of audited outturn figures for the previous year.

\section{Prepare Long-term Fiscal Projections}

98. Issue: Reducing Ireland's general government gross debt from 121 percent of GDP to the targeted 60 percent of GDP will require a long period of tight fiscal policy. In addition, Ireland faces growing demographic pressures, with the harmonized European estimate suggesting that age-related expenditure will increase by 7.4 percent of GDP by 2050. However, Ireland's fiscal projections only extend to 2015 — not far enough to demonstrate either (i) how and when Ireland expects to meet its debt target; or (ii) the impact of demographic and other long-term trends on the main fiscal aggregates.

\section{Recommendation 6: Regularly publish long-term fiscal projections as part of the annual budget documentation.}

a. Publish the government's own version of a debt-sustainability analysis, demonstrating the interaction of the new fiscal rules, extending out 10-20 years. This will demonstrate what the new rules mean for government expenditures and revenue trends, as well as how alternative macroeconomic scenarios influence both fiscal aggregates and the interaction of the rules.

b. Augment the internal long-term fiscal projection model and publish its projections at least every two-to-three years. This model will demonstrate the impact of ageing and health related expenditure pressures, and by including detailed entitlement data, will allow the impact of alternative expenditure policy changes on the long-term fiscal gap to be assessed.

\section{Reconcile Fiscal Forecast Changes}

100. Issue: Ireland's medium-term fiscal forecasts contain large revisions from one budget to the next. On a no-policy-change basis, between the SPU and 2013 Budget, tax revenues were revised down $€ 800 \mathrm{~m}$, and net expenditures were revised up by $€ 2.2$ billion. This required significant policy changes to remain within the program targets. While the 2013 Expenditure Report provides a detailed breakdown of changes to departmental expenditure ceilings since the last budget, it is difficult to understand the net impact of (i) changes in macroeconomic environment; (ii) changes to revenue and expenditure policies; and (iii) other technical or accounting changes on the fiscal forecast.

\section{Recommendation 7: Provide a more comprehensive reconciliation of changes to} key fiscal aggregates between successive fiscal forecasts. This can be done by comparing successive vintages of revenue and expenditure forecasts, and breaking down the variations in those forecasts between macroeconomic, policy, and technical changes. This will provide greater transparency about the factors that are driving changes to the forecast and how government policy is responding to them. It will also help to reinforce the credibility of the 
multi-year expenditure ceilings laid out in the MTEF by demonstrating that any new expenditure pressures or policies are being accommodated within those ceilings.

\section{8 and 9. Enhance Fiscal Risk Analysis}

102. Issue: The government publishes information on a wide range of fiscal risks, but the value of the information is diminished by being scattered among many documents published by many agencies. Moreover, much of the information is reported not by the ministries responsible for fiscal management - the Department of Finance and the Department of Public Expenditure and Reform - but by "outsiders" such as the Comptroller and AuditorGeneral, the Irish Fiscal Advisory Council, and the Central Bank.

103. The improvements in fiscal reporting discussed above would bring together much information relevant to an assessment of risk in two reports. Fiscal statistics for the public sector would allow a bird's-eye view of risks related to public corporations. Publication of financial statements and notes for consolidated central government would, among other things, generate integrated information on the government's assets and liabilities and notes on the risks around them.

104. However, those improvements will take time and will not be enough to bring together all the relevant information on fiscal risks into one place. Two new reports could help fill the gap: a comprehensive statement of fiscal risks and a report on the management of the government's portfolio of assets and liabilities.

105. Recommendation 8: The Department of Finance should publish as part of budget documentation a comprehensive annual statement of fiscal risks that include sections on:

a. macroeconomic analysis of risk (drawing on existing analysis published in the Medium-Term Fiscal Statement, the SPU, and IFAC's Fiscal Assessment Report);

b. specific revenue risks not reflected in macroeconomic analysis (Medium-Term Fiscal Statement);

c. contingent liabilities, including guarantees, insurance, callable capital, indemnities, litigation, etc., (Finance Accounts, C\&AG report, Appropriation Accounts - see also Tables below);

d. risks related to the financial sector in addition to those related to explicit guarantees (CBI Macro-Financial Review); and

e. risks related to values of assets and liabilities and associated cash flows, including debt, derivatives, financial assets, pensions, provisions, and PPPs (annual reports of NTMA, NPRF, State Claims, C\&AG report).

Appendix IV provides a possible outline for such a fiscal risk statement.

106. Recommendation 9: The Department of Finance or NTMA should publish an annual report on the government's strategy for the management of its portfolio of assets and liabilities, including debt, the NPRF fund, and shares in financial and nonfinancial corporations. 


\section{Harmonize Financial Reporting Standards and Practices}

107. Issue: There is no permanent official or unit in the Irish administration responsible for setting and enforcing financial reporting standards across the public sector. ${ }^{23}$ As a result, there is no uniform set of accounting rule and procedures applying to government departments, extra-budgetary funds, semi-state bodies, local governments, and public corporations. This makes consolidating government-wide financial information and promoting system-wide improvements in financial reporting practices very costly and timeconsuming.

108. Recommendation 10: Establish a permanent government financial reporting unit in the DoF or DPER headed by a Chief Financial Officer (CFO) or Director of Government Accounting (DGA). This may also require legislative changes to give the required authority to the CFO/DGA. The CFO/DGA should be appropriately qualified with considerable accounting, financial reporting and other relevant experience. He should be supported by a small group of finance professions and be responsible for:

a. setting financial reporting standards for all public sector entities, based on international and European accounting and statistical standards;

b. enforcement of those standards in the preparation of in-year and year-end financial reports by public sector bodies;

c. preparation and transmission of the proposed consolidated Central Government Financial Statements to the $C \& A G$ for audit;

d. cooperation with the CSO, DECLG, CBI, and other public entities on the preparation of fiscal statistics for the general government and public sector; and

e. establishing and maintaining professional standards for the government accounting profession.

The Fiscal Transparency Action Plan in Chapter V breaks each of these recommendations down into the sequence of specific actions that could to be taken over the next five years to implement these recommendations and identifies the agencies responsible for each.

\footnotetext{
${ }^{23}$ However, the Government Accounting Section in the DPER is responsible for prescribing accounting procedures for preparing the Voted accounts subject to the overarching provisions of the Exchequer and Audit Departments Act, 1866.
} 


\section{Fiscal Transparency ACtion Plan}

\begin{tabular}{|c|c|c|c|c|c|c|}
\hline Action & 2013 & 2014 & 2015 & 2016 & 2017 & $\begin{array}{c}\text { Responsible } \\
\text { Agencies * }\end{array}$ \\
\hline \multicolumn{7}{|c|}{ 1. Expand Institutional Coverage of Budgets, Statistics, and Accounts } \\
\hline $\begin{array}{l}\text { a. Present all gross } \\
\text { revenues and } \\
\text { expenditures of } \\
\text { central government } \\
\text { entities in budget } \\
\text { documentation }\end{array}$ & & $\begin{array}{l}\text { Incorporate NPRF } \\
\text { into budget } \\
\text { documentation }\end{array}$ & $\begin{array}{c}\text { Incorporate Non- } \\
\text { Commercial Semi- } \\
\text { State Bodies into } \\
\text { budget } \\
\text { documentation }\end{array}$ & $\begin{array}{l}\text { Incorporate all } \\
\text { central } \\
\text { government } \\
\text { entities in budget } \\
\text { documentation }\end{array}$ & $\begin{array}{l}\text { Integrate non- } \\
\text { commercial semi- } \\
\text { state bodies into } \\
\text { departmental } \\
\text { votes }\end{array}$ & $\begin{array}{l}\text { DoF } \\
\text { DPER }\end{array}$ \\
\hline $\begin{array}{l}\text { b. Combine Finance } \\
\text { and Appropriation } \\
\text { Accounts into a } \\
\text { consolidated Central } \\
\text { Government } \\
\text { Financial Statement }\end{array}$ & $\begin{array}{l}\text { Combine the } \\
\text { information in the } \\
\text { notes to the } \\
\text { Appropriation } \\
\text { Accounts to } \\
\text { produce a } \\
\text { summary report }\end{array}$ & $\begin{array}{l}\text { Combine Finance } \\
\text { and Appropriation } \\
\text { Accounts into a } \\
\text { partial Central } \\
\text { Government } \\
\text { Financial Statement } \\
\text { based on existing } \\
\text { accounting policies }\end{array}$ & $\begin{array}{l}\text { Incorporate SIF and } \\
\text { NPRF into partial } \\
\text { Central } \\
\text { Government } \\
\text { Financial Statement }\end{array}$ & $\begin{array}{l}\text { Incorporate Non- } \\
\text { Commercial Semi- } \\
\text { State Bodies into } \\
\text { consolidated } \\
\text { provisional Central } \\
\text { Government } \\
\text { Financial } \\
\text { Statement }\end{array}$ & $\begin{array}{c}\text { Prepare } \\
\text { comprehensive } \\
\text { consolidated } \\
\text { Central } \\
\text { Government } \\
\text { Financial } \\
\text { Statement for audit } \\
\text { by C\&AG }\end{array}$ & $\begin{array}{c}\text { DoF } \\
\text { DPER }\end{array}$ \\
\hline $\begin{array}{l}\text { C. Provide an overview } \\
\text { of the gross } \\
\text { revenues and } \\
\text { expenditures of the } \\
\text { general government } \\
\text { and its subsectors }\end{array}$ & $\begin{array}{l}\text { Reconcile gross } \\
\text { revenues and } \\
\text { expenditures of } \\
\text { Exchequer and } \\
\text { general } \\
\text { government in } \\
\text { budget }\end{array}$ & $\begin{array}{l}\text { Provide summary of } \\
\text { gross revenues and } \\
\text { expenditures of } \\
\text { central government } \\
\text { in budget }\end{array}$ & $\begin{array}{l}\text { Provide summary of } \\
\text { gross revenues and } \\
\text { expenditures of } \\
\text { central, local, and } \\
\text { general government } \\
\text { in budget }\end{array}$ & $\begin{array}{l}\text { Publish quarterly } \\
\text { statistics on gross } \\
\text { revenues and } \\
\text { expenditures of } \\
\text { central, local, and } \\
\text { general } \\
\text { government } \\
\text { sectors }\end{array}$ & $\begin{array}{l}\text { Publish monthly } \\
\text { statistics on gross } \\
\text { revenues and } \\
\text { expenditures of } \\
\text { central, local, and } \\
\text { general } \\
\text { government } \\
\text { sectors }\end{array}$ & $\begin{array}{l}\text { DoF: } 2013-15 \\
\text { CSO: 2016-17 } \\
\text { DPER }\end{array}$ \\
\hline
\end{tabular}

* Bold = Lead Agencies 


\begin{tabular}{|c|c|c|c|c|c|c|}
\hline Action & 2013 & 2014 & 2015 & 2016 & 2017 & $\begin{array}{c}\text { Responsible } \\
\text { Agencies * }\end{array}$ \\
\hline $\begin{array}{l}\text { d. Prepare fiscal } \\
\text { statistics for the } \\
\text { consolidated public } \\
\text { sector and its } \\
\text { subsectors }\end{array}$ & & $\begin{array}{l}\text { Prepare overview of } \\
\text { the financial } \\
\text { performance of } \\
\text { public corporations } \\
\text { sector }\end{array}$ & $\begin{array}{l}\text { Prepare annual } \\
\text { statistics for the } \\
\text { consolidated non- } \\
\text { financial public } \\
\text { sector (except for } \\
\text { those about to be } \\
\text { sold) }\end{array}$ & $\begin{array}{l}\text { Prepare annual } \\
\text { statistics for the } \\
\text { consolidated } \\
\text { public sector }\end{array}$ & $\begin{array}{l}\text { Prepare quarterly } \\
\text { statistics for the } \\
\text { consolidated } \\
\text { public sector }\end{array}$ & $\begin{array}{l}\text { DoF: } 2014 \\
\text { DPER } \\
\text { CSO: } 2015-17\end{array}$ \\
\hline \multicolumn{7}{|c|}{ 2. Recognize a Wider Range of Assets and Liabilities in Balance Sheets } \\
\hline $\begin{array}{l}\text { a. Revalue and } \\
\text { recognize accrued } \\
\text { pension liabilities of } \\
\text { public servants }\end{array}$ & & $\begin{array}{l}\text { Update the } \\
\text { estimate of the } \\
\text { present value of } \\
\text { pension liabilities }\end{array}$ & $\begin{array}{c}\text { Report pension } \\
\text { liabilities in a note } \\
\text { to Central } \\
\text { Government } \\
\text { Financial Statement }\end{array}$ & $\begin{array}{c}\text { Recognize } \\
\text { pension liabilities } \\
\text { in balance sheet of } \\
\text { Central } \\
\text { Government } \\
\text { Financial } \\
\text { Statement }\end{array}$ & $\begin{array}{l}\text { Update the } \\
\text { valuation of the } \\
\text { present value of } \\
\text { pension liabilities }\end{array}$ & $\begin{array}{l}\text { DPER } \\
\text { CSO } \\
\text { DoF }\end{array}$ \\
\hline $\begin{array}{l}\text { b. Recognize } \\
\text { government assets } \\
\text { and liabilities } \\
\text { associated with } \\
\text { PPPs }\end{array}$ & & $\begin{array}{l}\text { Report major PPP } \\
\text { assets and liabilities } \\
\text { in a note to the } \\
\text { central government } \\
\text { balance sheet }\end{array}$ & $\begin{array}{l}\text { Recognize major } \\
\text { PPP assets and } \\
\text { liabilities in the } \\
\text { central government } \\
\text { balance sheet }\end{array}$ & $\begin{array}{l}\text { Recognize and } \\
\text { report all PPP } \\
\text { assets and } \\
\text { liabilities in the } \\
\text { central } \\
\text { government } \\
\text { balance sheet }\end{array}$ & $\begin{array}{l}\text { Recognize and } \\
\text { report all PPP } \\
\text { assets and } \\
\text { liabilities in central, } \\
\text { local, and general } \\
\text { government } \\
\text { balance sheet }\end{array}$ & $\begin{array}{l}\text { DPER } \\
\text { CSO } \\
\text { DoF }\end{array}$ \\
\hline $\begin{array}{l}\text { c. Revalue and } \\
\text { recognize non- } \\
\text { financial assets of } \\
\text { central government }\end{array}$ & & $\begin{array}{l}\text { Complete the non- } \\
\text { financial asset } \\
\text { registers of Non- } \\
\text { Commercial Semi- } \\
\text { State Bodies and } \\
\text { EBFs }\end{array}$ & $\begin{array}{l}\text { Revalue the major } \\
\text { non-financial assets } \\
\text { of central } \\
\text { government } \\
\text { departments and of } \\
\text { Local Authorities }\end{array}$ & $\begin{array}{c}\text { Revalue the major } \\
\text { non-financial } \\
\text { assets of Non- } \\
\text { Commercial Semi- } \\
\text { State Bodies and } \\
\text { EBFs }\end{array}$ & $\begin{array}{c}\text { Include all } \\
\text { revalued non- } \\
\text { financial assets in } \\
\text { the Central and } \\
\text { local government } \\
\text { Financial } \\
\text { Statements in line } \\
\text { with international } \\
\text { standards }\end{array}$ & $\begin{array}{l}\text { DPER } \\
\text { Depts } \\
\text { SSBs } \\
\text { EBFs } \\
\text { CSO } \\
\text { DoF } \\
\text { Las }\end{array}$ \\
\hline
\end{tabular}




\begin{tabular}{|c|c|c|c|c|c|c|}
\hline Action & 2013 & 2014 & 2015 & 2016 & 2017 & $\begin{array}{c}\text { Responsible } \\
\text { Agencies * }\end{array}$ \\
\hline $\begin{array}{l}\text { d. Prepare and publish } \\
\text { a financial and full } \\
\text { balance sheet for the } \\
\text { public sector and its } \\
\text { subsectors }\end{array}$ & $\begin{array}{c}\text { Publish a } \\
\text { financial balance } \\
\text { sheet for the } \\
\text { general } \\
\text { government } \\
\text { sector }\end{array}$ & $\begin{array}{l}\text { Publish a financial } \\
\text { balance sheet for } \\
\text { the central and } \\
\text { general government } \\
\text { sectors }\end{array}$ & $\begin{array}{l}\text { Publish a full } \\
\text { balance sheet for } \\
\text { budgetary central } \\
\text { government }\end{array}$ & $\begin{array}{l}\text { Publish a full } \\
\text { balance sheet for } \\
\text { consolidated } \\
\text { central } \\
\text { government }\end{array}$ & $\begin{array}{l}\text { Prepare a full } \\
\text { balance sheet for } \\
\text { the public sector } \\
\text { and its subsectors }\end{array}$ & $\begin{array}{l}\text { CSO:2013-14 } \\
\text { DoF: } 2015-17 \\
\text { DPER } \\
\text { DECLG } \\
\text { LAs }\end{array}$ \\
\hline \multicolumn{7}{|c|}{ 3. Incorporate Accrued Economic Flows in Fiscal Documentation } \\
\hline $\begin{array}{l}\text { a. Reflect changes in } \\
\text { accrued public } \\
\text { sector pension } \\
\text { liabilities in budget } \\
\text { documentation, } \\
\text { statistics, and } \\
\text { accounts }\end{array}$ & & & & $\begin{array}{c}\text { Incorporate } \\
\text { estimated } \\
\text { valuation changes } \\
\text { in pension } \\
\text { liabilities as a non- } \\
\text { cash flow in } \\
\text { Central and local } \\
\text { Govt. revenues } \\
\text { and expenditures }\end{array}$ & $\begin{array}{l}\text { Report valuation } \\
\text { changes in } \\
\text { pension liabilities } \\
\text { in Central and } \\
\text { local government } \\
\text { Financial } \\
\text { Statements in line } \\
\text { with international } \\
\text { standards }\end{array}$ & $\begin{array}{l}\text { DoF } \\
\text { DPER } \\
\text { CSO } \\
\text { LAs }\end{array}$ \\
\hline $\begin{array}{l}\text { b. Incorporate } \\
\text { information on } \\
\text { annual flow of govt. } \\
\text { investments and } \\
\text { payments under } \\
\text { PPPs into fiscal } \\
\text { projections, } \\
\text { budgets, and } \\
\text { accounts }\end{array}$ & & $\begin{array}{l}\text { Include in budget } \\
\text { documentation } \\
\text { estimated annual } \\
\text { investments and } \\
\text { payments under } \\
\text { major PPPs of } \\
\text { central government }\end{array}$ & $\begin{array}{l}\text { Include in budget } \\
\text { documentation } \\
\text { estimated annual } \\
\text { investments and } \\
\text { payments under } \\
\text { major PPPs of } \\
\text { central and local } \\
\text { governments }\end{array}$ & $\begin{array}{l}\text { Incorporate } \\
\text { estimated annual } \\
\text { investments and } \\
\text { payments under } \\
\text { major PPPs of } \\
\text { Central and local } \\
\text { governments in } \\
\text { the accounts }\end{array}$ & $\begin{array}{l}\text { Incorporate annual } \\
\text { investments and } \\
\text { payments under } \\
\text { PPPs of General } \\
\text { Government in the } \\
\text { financial } \\
\text { statements }\end{array}$ & $\begin{array}{c}\text { DPER: } 2014-15 \\
\text { DoF: } 2016-17 \\
\text { CSO }\end{array}$ \\
\hline
\end{tabular}




\begin{tabular}{|c|c|c|c|c|c|c|}
\hline Action & 2013 & 2014 & 2015 & 2016 & 2017 & $\begin{array}{l}\text { Responsible } \\
\text { Agencies * }\end{array}$ \\
\hline $\begin{array}{l}\text { c. Use department- } \\
\text { specific depreciation } \\
\text { figures in summary } \\
\text { statistics and } \\
\text { accounts }\end{array}$ & & & $\begin{array}{l}\text { Recognize central } \\
\text { government } \\
\text { department specific } \\
\text { depreciation in } \\
\text { statistics }\end{array}$ & $\begin{array}{l}\text { Recognize CG } \\
\text { department and } \\
\text { local government } \\
\text { specific } \\
\text { depreciation in } \\
\text { statistics }\end{array}$ & $\begin{array}{l}\text { Recognize CG } \\
\text { department and } \\
\text { local government } \\
\text { specific } \\
\text { depreciation in } \\
\text { accounts }\end{array}$ & $\begin{array}{l}\text { DoF } \\
\text { DPER Depts } \\
\text { LAs }\end{array}$ \\
\hline $\begin{array}{l}\text { d. Recognize valuation } \\
\text { changes in public } \\
\text { sector assets, } \\
\text { liabilities, and } \\
\text { contingent liabilities } \\
\text { in fiscal } \\
\text { documentation }\end{array}$ & & & $\begin{array}{c}\text { Disclose estimated } \\
\text { valuation changes } \\
\text { of Central } \\
\text { Government assets } \\
\text { and liabilities in the } \\
\text { budget }\end{array}$ & $\begin{array}{l}\text { Disclose valuation } \\
\text { changes of Central } \\
\text { and local } \\
\text { government assets } \\
\text { and liabilities in } \\
\text { budget and } \\
\text { accounts }\end{array}$ & $\begin{array}{l}\text { Disclose valuation } \\
\text { changes of Central } \\
\text { and local govt. } \\
\text { assets, liabilities } \\
\text { and contingent } \\
\text { liabilities in budget } \\
\text { and accounts }\end{array}$ & \begin{tabular}{|} 
DPER (budget) \\
DoF (accounts) \\
DECLG \\
CSO
\end{tabular} \\
\hline $\begin{array}{l}\text { e. Provide a more } \\
\text { comprehensive } \\
\text { estimate of revenue } \\
\text { foregone from all tax } \\
\text { expenditures }\end{array}$ & & $\begin{array}{l}\text { Estimate and report } \\
\text { revenue foregone } \\
\text { from VAT }\end{array}$ & $\begin{array}{l}\text { Estimate and report } \\
\text { revenue foregone } \\
\text { from VAT, capital } \\
\text { gains tax, and } \\
\text { property tax }\end{array}$ & $\begin{array}{l}\text { Estimate and } \\
\text { report revenue } \\
\text { foregone from all } \\
\text { tax expenditures }\end{array}$ & & $\begin{array}{c}\text { DoF } \\
\text { Revenue } \\
\text { Commission } \\
\text { CSO }\end{array}$ \\
\hline \multicolumn{7}{|c|}{ 4. Bring the Classification of Fiscal Documentation into Line with International Standards } \\
\hline $\begin{array}{l}\text { a. Revise exchequer } \\
\text { statement to present } \\
\text { gross revenues and } \\
\text { expenditures and } \\
\text { distinguish financial } \\
\text { and nonfinancial } \\
\text { transactions }\end{array}$ & $\begin{array}{c}\text { Produce a } \\
\text { complementary } \\
\text { Exchequer } \\
\text { Statement using } \\
\text { a bridging table } \\
\text { on a monthly } \\
\text { basis }\end{array}$ & & $\begin{array}{l}\text { Develop a new } \\
\text { coding system to } \\
\text { distinguish non- } \\
\text { financial and } \\
\text { financial } \\
\text { transactions }\end{array}$ & $\begin{array}{l}\text { Incorporate the } \\
\text { new coding } \\
\text { system into chart } \\
\text { of accounts }\end{array}$ & $\begin{array}{l}\text { Generate both the } \\
\text { standard and } \\
\text { alternative } \\
\text { exchequer } \\
\text { statements using } \\
\text { the revised chart } \\
\text { of accounts }\end{array}$ & $\begin{array}{l}\text { DoF } \\
\text { CSO }\end{array}$ \\
\hline
\end{tabular}




\begin{tabular}{|c|c|c|c|c|c|c|}
\hline Action & 2013 & 2014 & 2015 & 2016 & 2017 & $\begin{array}{l}\text { Responsible } \\
\text { Agencies * }\end{array}$ \\
\hline $\begin{array}{l}\text { b. Develop an } \\
\text { exhaustive program } \\
\text { classification that } \\
\text { can be mapped to } \\
\text { output/impact } \\
\text { indicators and } \\
\text { COFOG sectors }\end{array}$ & $\begin{array}{l}\text { Review program } \\
\text { classification for } \\
\text { harmonizing its } \\
\text { structure across } \\
\text { Votes and bring it } \\
\text { into line with } \\
\text { COFOG }\end{array}$ & $\begin{array}{l}\text { Develop a } \\
\text { harmonized two } \\
\text { level program } \\
\text { classification, with } \\
\text { second level } \\
\text { mapped to COFOG }\end{array}$ & $\begin{array}{l}\text { Roll out the new } \\
\text { program } \\
\text { classification to } \\
\text { Departments }\end{array}$ & $\begin{array}{l}\text { Incorporate the } \\
\text { new program } \\
\text { classification into } \\
\text { chart of accounts }\end{array}$ & $\begin{array}{l}\text { Generate } \\
\text { Estimates, } \\
\text { COFOG, and } \\
\text { management } \\
\text { reports using the } \\
\text { new program } \\
\text { classification }\end{array}$ & $\begin{array}{l}\text { DPER } \\
\text { DoF } \\
\text { Depts } \\
\text { CSO }\end{array}$ \\
\hline $\begin{array}{l}\text { c. Develop a } \\
\text { harmonized chart of } \\
\text { accounts for all } \\
\text { public sector entities }\end{array}$ & $\begin{array}{l}\text { Complete the } \\
\text { baseline } \\
\text { assessment } \\
\text { under the shared } \\
\text { services project }\end{array}$ & $\begin{array}{l}\text { Identify common } \\
\text { information } \\
\text { requirements for } \\
\text { GFS and financial } \\
\text { reporting }\end{array}$ & $\begin{array}{l}\text { Develop a parent } \\
\text { chart of accounts } \\
\text { that meets the } \\
\text { common } \\
\text { requirements }\end{array}$ & $\begin{array}{l}\text { Rollout the new } \\
\text { chart of accounts } \\
\text { to all general } \\
\text { government } \\
\text { entities }\end{array}$ & $\begin{array}{l}\text { Rollout the new } \\
\text { chart of accounts } \\
\text { to all public sector } \\
\text { entities }\end{array}$ & $\begin{array}{l}\text { DPER } \\
\text { DoF } \\
\text { DECLG } \\
\text { LA } \\
\text { CSO }\end{array}$ \\
\hline \multicolumn{7}{|c|}{ 5. Accelerate the Production, Presentation, and Approval of the Annual Budget and Accounts } \\
\hline $\begin{array}{l}\text { a. Submit the annual } \\
\text { budget to parliament } \\
\text { in October }\end{array}$ & $\begin{array}{l}\text { Submit Economic } \\
\text { \& Fiscal Outlook } \\
\text { by October and } \\
\text { Expenditure } \\
\text { Report by } \\
\text { December }\end{array}$ & $\begin{array}{l}\text { Submit Economic \& } \\
\text { Fiscal Outlook and } \\
\text { Expenditure Report } \\
\text { by October and } \\
\text { REV in December }\end{array}$ & $\begin{array}{l}\text { Submit Economic \& } \\
\text { Fiscal Outlook, } \\
\text { Expenditure Report, } \\
\text { and REV in late } \\
\text { October/early } \\
\text { November }\end{array}$ & $\begin{array}{l}\text { Submit Economic } \\
\text { \& Fiscal Outlook, } \\
\text { Expenditure } \\
\text { Report, REV, and } \\
\text { Finance Bill in late } \\
\text { October/early } \\
\text { November }\end{array}$ & & $\begin{array}{l}\text { DoF } \\
\text { DPER }\end{array}$ \\
\hline $\begin{array}{l}\text { b. Approve the annual } \\
\text { budget in December }\end{array}$ & & $\begin{array}{l}\text { Approve the } \\
\text { Estimates by March } \\
\text { of the budget year }\end{array}$ & $\begin{array}{l}\text { Approve the } \\
\text { Estimates before } \\
\text { the budget year }\end{array}$ & $\begin{array}{l}\text { Approve the } \\
\text { Estimates and } \\
\text { Finance Bill before } \\
\text { the budget year }\end{array}$ & & $\begin{array}{l}\text { DoF } \\
\text { DPER }\end{array}$ \\
\hline
\end{tabular}




\begin{tabular}{|c|c|c|c|c|c|c|}
\hline Action & 2013 & 2014 & 2015 & 2016 & 2017 & $\begin{array}{c}\text { Responsible } \\
\text { Agencies * }\end{array}$ \\
\hline $\begin{array}{l}\text { c. Submit the annual } \\
\text { accounts for audit } \\
\text { by March }\end{array}$ & & $\begin{array}{c}\text { Submit partial } \\
\text { Central Govt. } \\
\text { Financial Statement } \\
\text { for "dry run" audit } \\
\text { by Sept }\end{array}$ & $\begin{array}{l}\text { Submit partial } \\
\text { Central Govt. } \\
\text { Financial Statement } \\
\text { for "dry run" audit } \\
\text { by June }\end{array}$ & $\begin{array}{l}\text { Submit for "dry } \\
\text { run" audit } \\
\text { consolidated } \\
\text { provisional Central } \\
\text { Govt. Financial } \\
\text { Statement by April }\end{array}$ & $\begin{array}{l}\text { Submit by March } \\
\text { consolidated } \\
\text { Central Govt. } \\
\text { Financial } \\
\text { Statement for audit }\end{array}$ & $\begin{array}{l}\text { DoF } \\
\text { DPER } \\
\text { Depts }\end{array}$ \\
\hline $\begin{array}{l}\text { d. Submit the audited } \\
\text { accounts to } \\
\text { Parliament by June }\end{array}$ & & $\begin{array}{c}\text { "Dry run"audit of } \\
\text { partial Central Govt. } \\
\text { Financial Statement } \\
\text { by December }\end{array}$ & $\begin{array}{l}\text { "Dry run" audit of } \\
\text { partial Central Govt. } \\
\text { Financial Statement } \\
\text { and informal audit } \\
\text { opinion on IPSAS } \\
\text { based entity } \\
\text { accounts by } \\
\text { September }\end{array}$ & $\begin{array}{l}\text { "Dry run" audit of } \\
\text { consolidated } \\
\text { provisional Central } \\
\text { Govt. Financial } \\
\text { Statement by June } \\
\text { and informal audit } \\
\text { opinion by } \\
\text { September }\end{array}$ & $\begin{array}{l}\text { Full published } \\
\text { audit of and formal } \\
\text { audit opinion on } \\
\text { consolidated } \\
\text { Central Govt. } \\
\text { Financial } \\
\text { Statement by June }\end{array}$ & $\begin{array}{c}\text { DoF } \\
\text { C\&AG }\end{array}$ \\
\hline \multicolumn{7}{|c|}{ 6. Prepare and Publish Long-term Fiscal Projections } \\
\hline $\begin{array}{l}\text { a. Publish a debt- } \\
\text { sustainability } \\
\text { analysis, showing } \\
\text { the interaction of the } \\
\text { new fiscal rules, for } \\
\text { next } 10-20 \text { years }\end{array}$ & $\begin{array}{l}\text { Project main } \\
\text { fiscal aggregates } \\
\text { for next } 5 \text { years, } \\
\text { including impact } \\
\text { of fiscal rules }\end{array}$ & $\begin{array}{l}\text { Project main fiscal } \\
\text { aggregates for next } \\
10 \text { years, including } \\
\text { impact of fiscal } \\
\text { rules }\end{array}$ & $\begin{array}{l}\text { Project main fiscal } \\
\text { aggregates under } \\
\text { alternative } \\
\text { scenarios for } 20 \\
\text { years, incl. impact } \\
\text { of fiscal rules }\end{array}$ & & & $\begin{array}{c}\text { DoF } \\
\text { NTMA }\end{array}$ \\
\hline $\begin{array}{l}\text { b. Develop an internal } \\
\text { long-term (50 years) } \\
\text { fiscal projection } \\
\text { model and publish } \\
\text { its projections every } \\
\text { two-to-three years }\end{array}$ & $\begin{array}{l}\text { Develop model } \\
\text { for long-term } \\
\text { demographic, } \\
\text { economic, } \\
\text { revenue and } \\
\text { expenditure to } \\
\text { calculate the } \\
\text { fiscal gap }\end{array}$ & $\begin{array}{l}\text { Publish first long- } \\
\text { term fiscal } \\
\text { sustainability } \\
\text { projections based } \\
\text { on a single scenario }\end{array}$ & $\begin{array}{l}\text { Expand model to } \\
\text { run alternative } \\
\text { demographic, } \\
\text { macroeconomic, } \\
\text { and policy } \\
\text { scenarios }\end{array}$ & $\begin{array}{l}\text { Used long-term } \\
\text { fiscal sustainability } \\
\text { model to inform } \\
\text { policy decisions }\end{array}$ & $\begin{array}{l}\text { Publish long-term } \\
\text { fiscal sustainability } \\
\text { reports based on a } \\
\text { range of } \\
\text { demographic, } \\
\text { macroeconomic, } \\
\text { and policy } \\
\text { scenarios }\end{array}$ & $\begin{array}{l}\text { DoF } \\
\text { DPER } \\
\text { IFAC }\end{array}$ \\
\hline
\end{tabular}




\begin{tabular}{|c|c|c|c|c|c|c|}
\hline Action & 2013 & 2014 & 2015 & 2016 & 2017 & $\begin{array}{c}\text { Responsible } \\
\text { Agencies * }\end{array}$ \\
\hline \multicolumn{7}{|c|}{ 7. Reconcile Fiscal Forecast Changes } \\
\hline $\begin{array}{l}\text { Provide a more } \\
\text { comprehensive } \\
\text { reconciliation of } \\
\text { changes to key fiscal } \\
\text { aggregates between } \\
\text { successive fiscal } \\
\text { forecasts }\end{array}$ & $\begin{array}{l}\text { Compare } 2013 \\
\text { Budget, } 2014 \\
\text { SPU and } 2014 \\
\text { Budget and show } \\
\text { the impact of } \\
\text { macroeconomic, } \\
\text { policy, and } \\
\text { technical } \\
\text { changes on } \\
\text { forecasts of } \\
\text { revenue, } \\
\text { expenditure, and } \\
\text { balance }\end{array}$ & $\begin{array}{c}\text { Explain changes to } \\
\text { fiscal aggregates } \\
\text { between } \\
\text { successive fiscal } \\
\text { forecasts showing } \\
\text { the effects of } \\
\text { macroeconomic, } \\
\text { policy, and } \\
\text { technical changes. }\end{array}$ & & & & $\begin{array}{c}\text { DoF } \\
\text { DPER }\end{array}$ \\
\hline \multicolumn{7}{|c|}{ 8. Publish a Statement of Fiscal Risks } \\
\hline $\begin{array}{l}\text { Publish as part of } \\
\text { budget } \\
\text { documentation a } \\
\text { comprehensive } \\
\text { statement of fiscal } \\
\text { risks }\end{array}$ & $\begin{array}{l}\text { Prepare fiscal risk } \\
\text { statement for } \\
\text { internal } \\
\text { management } \\
\text { purposes }\end{array}$ & $\begin{array}{l}\text { Publish fiscal risk } \\
\text { statement } \\
\text { discussing } \\
\text { macroeconomic } \\
\text { risks, specific } \\
\text { revenue risks, and } \\
\text { contingent liabilities }\end{array}$ & $\begin{array}{l}\text { Publish fiscal risk } \\
\text { statement on risks } \\
\text { related to } \\
\text { macroeconomic } \\
\text { factors, contingent } \\
\text { liabilities, and } \\
\text { financial sector } \\
\text { exposure }\end{array}$ & $\begin{array}{l}\text { Publish fiscal risk } \\
\text { statement on risks } \\
\text { related to } \\
\text { macroeconomic } \\
\text { factors, contingent } \\
\text { liabilities, financial } \\
\text { sector exposure, } \\
\text { and values of } \\
\text { assets \& liabilities }\end{array}$ & $\begin{array}{l}\text { Publish fiscal risk } \\
\text { statement on risks } \\
\text { related to } \\
\text { macroeconomic } \\
\text { factors, contingent } \\
\text { liabilities, financial } \\
\text { sector exposure, } \\
\text { assets \& liabilities, } \\
\text { and their likelihood }\end{array}$ & $\begin{array}{c}\text { DoF } \\
\text { DPER }\end{array}$ \\
\hline
\end{tabular}




\begin{tabular}{|c|c|c|c|c|c|c|}
\hline Action & 2013 & 2014 & 2015 & 2016 & 2017 & $\begin{array}{l}\text { Responsible } \\
\text { Agencies * }\end{array}$ \\
\hline \multicolumn{7}{|c|}{ 9. Publish an Asset and Liability Management Strategy } \\
\hline $\begin{array}{l}\text { Publish a report on } \\
\text { the government's } \\
\text { strategy for the } \\
\text { management of its } \\
\text { portfolio of assets } \\
\text { and liabilities }\end{array}$ & & $\begin{array}{l}\text { Publish a debt } \\
\text { management } \\
\text { strategy }\end{array}$ & $\begin{array}{l}\text { Publish a strategy } \\
\text { for management of } \\
\text { debt and NPRF }\end{array}$ & $\begin{array}{l}\text { Publish a strategy } \\
\text { for management of } \\
\text { debt, NPRF and } \\
\text { shares in non- } \\
\text { financial } \\
\text { corporations }\end{array}$ & $\begin{array}{l}\text { Publish a strategy } \\
\text { for management of } \\
\text { debt, NPRF and } \\
\text { shares in financial } \\
\text { and non-financial } \\
\text { corporations }\end{array}$ & $\begin{array}{c}\text { DoF } \\
\text { DPER } \\
\text { NTMA } \\
\text { New ERA }\end{array}$ \\
\hline \multicolumn{7}{|c|}{ 10. Harmonize Public Sector Financial Reporting Standards and Practices } \\
\hline $\begin{array}{l}\text { Establish a } \\
\text { permanent financial } \\
\text { reporting unit in the } \\
\text { DoF headed by a } \\
\text { Chief Financial } \\
\text { Officer (CFO) or } \\
\text { Director of } \\
\text { Government } \\
\text { Accounting (DGA) }\end{array}$ & $\begin{array}{c}\text { Establish a } \\
\text { permanent } \\
\text { government } \\
\text { financial reporting } \\
\text { unit, and recruit } \\
\text { the CFO/DGA }\end{array}$ & $\begin{array}{l}\text { Start developing } \\
\text { accounting rules/ } \\
\text { policies and } \\
\text { standards for public } \\
\text { sector, produce } \\
\text { FRS based } \\
\text { accounts, \& build } \\
\text { accounting capacity }\end{array}$ & $\begin{array}{l}\text { Conduct a trial (dry } \\
\text { run) of IPSAS } \\
\text { based individual } \\
\text { govt. entity } \\
\text { accounts and full } \\
\text { IFRS accounts for } \\
\text { all public } \\
\text { corporations to help } \\
\text { identify gaps }\end{array}$ & $\begin{array}{l}\text { Continue the trial } \\
\text { and legislate to } \\
\text { give authority to } \\
\text { the CFO/DGA for } \\
\text { preparation of } \\
\text { consolidated } \\
\text { Central } \\
\text { Government } \\
\text { Financial } \\
\text { Statement }\end{array}$ & $\begin{array}{l}\text { Produce fully } \\
\text { consolidated } \\
\text { Central } \\
\text { Government } \\
\text { Financial } \\
\text { Statement for audit } \\
\text { by C\&AG }\end{array}$ & $\begin{array}{c}\text { DoF } \\
\text { DPER } \\
\text { Cabinet } \\
\text { CSO } \\
\text { C\&AG } \\
\text { Parliament }\end{array}$ \\
\hline
\end{tabular}




\section{APPENDIX I. SUPPLEMENTARY TABLES}

Appendix IA: Consolidated General Government Gross Revenue and Expenditures

Appendix IB: Consolidated Central Government Gross Revenue and Expenditures

Appendix IC: Consolidated Central Government Financial Statement

Appendix ID: Overview of Revenue, Expenditure, and Balance by Subsector of General Govt

Appendix IE: Public Sector Balance Sheet by Segment, 2011

Appendix IF: Summary Table on Revisions to Exchequer Statement

Appendix IG: Mapping of Exchequer Statement to ESA 95 Classification 
Appendix 1A. Consolidated General Government Gross Revenue and Expenditure (By Sector)

\begin{tabular}{lrrr}
\hline & \multicolumn{3}{c}{2010} \\
\cline { 2 - 4 } & Revenue & \multicolumn{3}{c}{ Expenditure } & Balance \\
\hline Central Government & $\mathbf{5 1 , 8 4 7}$ & $\mathbf{1 0 2 , 1 0 1}$ & $\mathbf{- 5 0 , 2 5 4}$ \\
Exchequer (non-financial transactions) & 35,069 & 53,657 & $-18,588$ \\
$\quad$ Memo: Exchequer (receipts and issues) & 36,239 & 54,984 & $-\mathbf{1 8 , 7 4 5}$ \\
Appropriations in aid & 6,192 & 37,042 & $-30,850$ \\
Social insurance & 11,019 & 11,996 & -977 \\
Other extrabudgetary funds & 6,015 & 3,582 & 2,433 \\
Non-market semi states & 9,176 & 8,896 & 280 \\
Eliminations within CG & $-15,562$ & $-13,700$ & $-1,862$ \\
Cash to accrual adjustments & -62 & 628 & -690 \\
Local Government & $\mathbf{9 , 1 7 5}$ & $\mathbf{9 , 0 7 9}$ & $\mathbf{9 6}$ \\
Eliminations between LG and CG & $-5,835$ & $-5,835$ & 0 \\
General Government & $\mathbf{5 5 , 1 8 7}$ & $\mathbf{1 0 5 , 3 4 5}$ & $\mathbf{- 5 0 , 1 5 8}$ \\
\hline Percent of GDP & $\mathbf{3 5 . 3}$ & $\mathbf{6 7 . 3}$ & $\mathbf{- 3 2 . 0}$ \\
\hline GDP & 156500 & &
\end{tabular}

Memo

General Government Expenditure Benchmark

101,338

\begin{tabular}{lrrr}
\hline & \multicolumn{3}{c}{2011} \\
\cline { 2 - 4 } & Revenue & Expenditure & Balance \\
\hline Central Government & $\mathbf{5 2 , 4 1 0}$ & $\mathbf{7 6 , 1 7 4}$ & $\mathbf{- 2 3 , 7 6 4}$ \\
Exchequer (non-financial transactions) & 37,576 & 56,223 & $-18,647$ \\
Memo: Exchequer (receipts and issues) & 39,305 & 64,222 & $-24,917$ \\
Appropriations in aid & 4,026 & 4,026 & 0 \\
Social insurance & 9,720 & 9,646 & 74 \\
Other extrabudgetary funds & 4,094 & 7,986 & $-3,892$ \\
Non-market semi states & 7,641 & 7,665 & -24 \\
Eliminations within CG & $-11,208$ & $-9,050$ & $-2,158$ \\
Cash to accrual adjustments & 562 & -322 & 884 \\
Local Government & $\mathbf{8 , 2 9 4}$ & $\mathbf{8 , 2 8 4}$ & $\mathbf{1 0}$ \\
Eliminations between LG and CG & $-5,020$ & $-5,020$ & 0 \\
General Government & $\mathbf{5 5 , 6 8 4}$ & $\mathbf{7 7 , 2 7 9}$ & $\mathbf{- 2 1 , 5 9 5}$ \\
\hline Percent of GDP & $\mathbf{3 5 . 0}$ & $\mathbf{4 8 . 6}$ & $\mathbf{- 1 3 . 6}$ \\
\hline & 159000 & & \\
Memo & & &
\end{tabular}

General Government Expenditure Benchmark 


\section{Appendix 1B. Consolidated Central Government Gross Revenues and Expenditures (By Institution)}

Table 1: Central government Expenditure by Institution

\begin{tabular}{lrr}
\hline & 2010 & 2011 \\
\hline Gross Ministerial Voted & $\mathbf{6 4 , 6 2 2}$ & $\mathbf{5 9 , 3 8 3}$ \\
Net voted expenditure & 46,434 & 45,711 \\
Appropriations in aid & 6,192 & 4,026 \\
Social insurance & 11,996 & 9,646 \\
Non-voted Expenditure & $\mathbf{7 , 2 2 3}$ & $\mathbf{1 0 , 5 1 2}$ \\
Promissory Notes & $\mathbf{3 0 , 8 5 0}$ & $\mathbf{0}$ \\
Other extrabudgetary funds & $\mathbf{3 , 5 8 2}$ & $\mathbf{7 , 9 8 6}$ \\
NPRF & 21 & 4,037 \\
Local Govt Fund & 1,243 & 1,148 \\
Eligible Liabilities Bank Guarantee Scheme & 1,333 & 1,239 \\
Non-market semi-states & $\mathbf{8 , 8 9 6}$ & $\mathbf{7 , 6 6 5}$ \\
National Roads Authority & 1,689 & 1,334 \\
Higher Education Authority & 1,622 & 1,265 \\
Fas & 1,012 & 943 \\
Irish Rail & 779 & 526 \\
Eliminations & $\mathbf{1 3 , 7 0 0}$ & $\mathbf{- 9 , 0 5 0}$ \\
& $\mathbf{6 2 8}$ & $\mathbf{- 3 2 2}$ \\
Central Government & $\mathbf{1 0 2 , 1 0 1}$ & $\mathbf{7 6 , 1 7 4}$ \\
\hline
\end{tabular}

Table 2: Central government Revenue by Institution

\begin{tabular}{lrr}
\hline & 2010 & 2011 \\
\hline Tax Revenue & $\mathbf{3 1 , 7 5 3}$ & $\mathbf{3 4 , 0 2 7}$ \\
Non-Tax Revenue & $\mathbf{1 9 , 9 0 0}$ & $\mathbf{1 6 , 5 2 0}$ \\
Appropriations in Aid & 6,192 & 4,026 \\
Social insurance & 11,019 & 9,720 \\
Other non-tax revenue & 2,689 & 2,774 \\
Capital Receipts* & $\mathbf{6 2 8}$ & $\mathbf{7 7 5}$ \\
Other extrabudgetary funds & $\mathbf{6 , 0 1 5}$ & $\mathbf{4 , 0 9 4}$ \\
NPRF & 2,114 & 729 \\
Local Govt Fund & 1,264 & 1,188 \\
Eligible Liabilities Bank Guarantee Scheme & 1,074 & 1,236 \\
Non-market semi states & $\mathbf{9 , 1 7 6}$ & $\mathbf{7 , 6 4 1}$ \\
National Roads Authority & 1,740 & 1,369 \\
Higher Education Authority & 1,621 & 1,265 \\
Fas & 983 & 910 \\
Irish Rail & 838 & 539 \\
Eliminations & $\mathbf{- 1 5 , 5 6 2}$ & $\mathbf{- 1 1 , 2 0 8}$ \\
& $-\mathbf{6 2}$ & $\mathbf{5 6 2}$ \\
Central Government & $\mathbf{5 1 , 8 4 7}$ & $\mathbf{5 2 , 4 1 0}$ \\
\hline
\end{tabular}




\section{Appendix 1C. Consolidated Central Government Financial Statements}

Table 1: Central Government Balance Sheet

\begin{tabular}{lrr}
\hline & $\mathbf{2 0 1 0}$ & $\mathbf{2 0 1 1}$ \\
\hline Total Assets & & \\
& $\mathbf{6 2 , 9 7 0}$ & $\mathbf{6 0 , 3 7 8}$ \\
Financial assets & 17,414 & 16,961 \\
Currency and deposits & 10,720 & 7,910 \\
Securities other than shares & 5,174 & 6,165 \\
Loans & & \\
Promissory Notes & & \\
Government debt & 23,750 & 22,565 \\
Shares and other equity & 5,912 & \\
Other financial assets & & \\
& & \\
Non-Financial Assets & & $\mathbf{2 8 5 , 2 7 7}$ \\
& & 15,218 \\
Liabilities & $\mathbf{2 5 6 , 3 5 3}$ & 80,691 \\
Currency and deposits & 13,711 & 64,966 \\
Lecurities other than shares & 84,403 & 116,000 \\
Pension Liabilities & 33,610 & 8,402 \\
Other liabilities & 116,000 & \\
Provisions & 8,629 & \\
Financial assets net of liabilities & & $\mathbf{2 2 4 , 8 9 9}$ \\
Net worth & & \\
\hline
\end{tabular}

Table 2: Central government Revenues by Institution

\begin{tabular}{lrr}
\hline & $\mathbf{2 0 1 0}$ & $\mathbf{2 0 1 1}$ \\
\hline Gross Exchequer non-financial receipts & 52,280 & 51,322 \\
Tax Revenue & 31,753 & 34,027 \\
Non-Tax Revenue & 19,900 & 16,520 \\
Capital Receipts & 628 & 775 \\
Other extrabudgetary funds & 6,015 & 4,094 \\
Non-market semi states & 9,176 & 7,641 \\
Eliminations & $-15,562$ & $-11,208$ \\
Central Government & $\mathbf{5 1 , 9 0 9}$ & $\mathbf{5 1 , 8 4 8}$ \\
\hline
\end{tabular}

\begin{tabular}{lrr} 
Table 3: Central Government Expenditure by Institution \\
\hline \\
\hline Gross Exchequer non-financial payments & $\mathbf{2 0 1 0}$ & $\mathbf{2 0 1 1}$ \\
Gross Ministerial Voted & 71,845 & 69,895 \\
Non-voted Expenditure & 64,622 & 59,383 \\
Promissory Notes & 7,223 & 10,512 \\
Other extrabudgetary funds & 30,850 & 0 \\
Non-market semi states & 3,582 & 7,986 \\
Eliminations & 8,896 & 7,665 \\
Central Government & $-13,700$ & $-9,050$ \\
& $\mathbf{1 0 1 , 4 7 3}$ & $\mathbf{7 6 , 4 9 6}$ \\
\hline
\end{tabular}

\begin{tabular}{lrr} 
Table 4: Financing & & $\mathbf{2 0 1 1}$ \\
\hline & $\mathbf{2 0 1 0}$ & $\mathbf{- 2 4 , 6 4 8}$ \\
\hline Above the line balance & $\mathbf{- 4 9 , 5 6 4}$ & \\
& & 27,046 \\
Net acquisition of financial liabilities (exchequer) & 43,468 & -270 \\
Net acquisition of financial liabilities (other CG entities) & 126 & 0 \\
Net Acquisition of financial assets & 157 & 2,128 \\
Change in Bank deposits & -6127 & $\mathbf{2 4 , 6 4 8}$ \\
Net Financing & $\mathbf{4 9 , 5 6 4}$ &
\end{tabular}

Table 5: Other Economic Flows

\begin{tabular}{lr}
\hline & $\mathbf{2 0 1 0}$ \\
\hline Other changes in financial assets & $\mathbf{2 0 1 1}$ \\
Other changes in non-financial assets & $-\mathbf{4 , 7 2 0}$ \\
Other changes in liabilities & - \\
Total other economic flows & 2,148 \\
\hline
\end{tabular}


Appendix 1D. Overview of General Government Revenue, Expenditure and Balance by Subsector

\begin{tabular}{lrr}
\hline & 2010 & 2011 \\
\hline Central Government & 51,847 & 52,410 \\
Revenue & 102,101 & 76,174 \\
Expenditure & $-50,254$ & $-23,764$ \\
Balance & & \\
Local Government & 9,175 & 8,294 \\
Revenue & 9,079 & 8,284 \\
Expenditure & 96 & 10 \\
Balance & & \\
General Government & 55,187 & 55,684 \\
Revenue & 105,345 & 77,279 \\
Expenditure & $-50,158$ & $-21,595$ \\
Balance & & \\
\hline & & \\
Memo & 105,345 & 77,279 \\
General Government Expenditure & 3950.9 & 5662 \\
less interest & 56 & 82.5 \\
less EU capital exp & & \\
less Unemplyment benefits & 101,338 & 71,535 \\
General Government Expenditure Benchmark & & \\
& & \\
Eliminations & $-5,835$ & $-5,020$ \\
Revenue & $-5,835$ & $-5,020$ \\
Expenditure & 0 & 0 \\
Balance &
\end{tabular}


Appendix 1E. Public Sector Balance Sheet by Segment 2011

(Percent of GDP)

\begin{tabular}{|c|c|c|c|c|}
\hline & $\begin{array}{c}\text { General } \\
\text { Government }\end{array}$ & $\begin{array}{l}\text { Non-Financial } \\
\text { Public Sector }\end{array}$ & $\begin{array}{l}\text { Non-Monetary } \\
\text { Public Sector }\end{array}$ & $\begin{array}{l}\text { Public } \\
\text { Sector }\end{array}$ \\
\hline Total Assets & 112.7 & 124.5 & 264.1 & 317.0 \\
\hline Financial assets & 39.2 & 36.9 & 176.0 & 228.8 \\
\hline Currency and deposits & 11.3 & 12.3 & 16.4 & 29.9 \\
\hline Securities other than shares & 5.0 & 5.3 & 9.5 & 22.6 \\
\hline Loans & 2.8 & 2.8 & 109.2 & 109.2 \\
\hline Promissory Notes & 0.0 & 0.0 & 0.0 & 0.0 \\
\hline Government debt & 0.0 & 0.0 & 0.0 & 0.0 \\
\hline Shares and other equity* & 14.9 & 9.3 & -2.1 & -3.5 \\
\hline Other financial assets & 5.2 & 7.1 & 42.9 & 70.7 \\
\hline Non-Financial Assets & 73.5 & 87.6 & 88.1 & 88.1 \\
\hline Liabilities & 181.4 & 193.3 & 332.8 & 385.7 \\
\hline Currency and deposits & 9.6 & 9.6 & 117.8 & 83.6 \\
\hline Securities other than shares & 50.6 & 50.6 & 37.2 & 37.2 \\
\hline Loans & 41.3 & 46.6 & 64.9 & 64.9 \\
\hline Other liabilities & 79.9 & 86.5 & 112.9 & 200.0 \\
\hline Financial assets net of liabilities & -142.2 & -156.4 & -156.8 & -156.8 \\
\hline Net worth & -68.7 & -68.7 & -68.7 & -68.7 \\
\hline Flows & $\begin{array}{c}\text { General } \\
\text { Government }\end{array}$ & $\begin{array}{l}\text { Non-Financial } \\
\text { Public Sector }\end{array}$ & $\begin{array}{l}\text { Non-Monetary } \\
\text { Public Sector }\end{array}$ & $\begin{array}{l}\text { Public } \\
\text { Sector }\end{array}$ \\
\hline Revenue & 33.0 & 41.0 & 47.9 & 49.6 \\
\hline Expenditure & 46.6 & 54.4 & 59.9 & 60.5 \\
\hline Net lending & -13.6 & -13.4 & -12.0 & -10.9 \\
\hline Financing & $\begin{array}{c}\text { General } \\
\text { Government }\end{array}$ & $\begin{array}{l}\text { Non-Financial } \\
\text { Public Sector }\end{array}$ & $\begin{array}{l}\text { Non-Monetary } \\
\text { Public Sector }\end{array}$ & $\begin{array}{l}\text { Public } \\
\text { Sector }\end{array}$ \\
\hline $\begin{array}{l}\text { Net acquisition of financial assets } \\
\text { Net acquisition of financial liabilities } \\
\text { Net Financing }\end{array}$ & & & & \\
\hline Other economic flows (not availab & $\begin{array}{c}\text { General } \\
\text { Government }\end{array}$ & $\begin{array}{l}\text { Non-Financial } \\
\text { Public Sector }\end{array}$ & $\begin{array}{l}\text { Non-Monetary } \\
\text { Public Sector }\end{array}$ & $\begin{array}{l}\text { Public } \\
\text { Sector }\end{array}$ \\
\hline $\begin{array}{l}\text { Other changes in financial assets } \\
\text { Other changes in non-financial assets } \\
\text { Other changes in liabilities }\end{array}$ & & & & \\
\hline
\end{tabular}


Appendix 1F. Summary Table on Revisions to Exchequer Statement

\begin{tabular}{|c|c|c|c|}
\hline \multicolumn{2}{|l|}{ Current Presentation } & \multicolumn{2}{|l|}{ Recommended Presentation } \\
\hline Receipts and Expenditure - Current & & Total Revenue & $A=(a+b+c)$ \\
\hline Receipts & & Tax Revenue & $\mathrm{a}$ \\
\hline Tax Revenue & & Non-tax Revenue & b \\
\hline Non-Tax Revenue & & Capital Grants & c \\
\hline Total & A & & \\
\hline Expenditure & & Total Expenditure & $B=(d+e+f)$ \\
\hline Voted (Departmental Expenditure) & & Voted Departmental Expenditure & d \\
\hline Non-Voted Non-discretionary Expenditure & & Non-Voted Current Expenditure & $\mathrm{e}$ \\
\hline Sinking Fund & & Non-Voted Capital Expenditure & $\mathrm{f}$ \\
\hline \multicolumn{4}{|l|}{ Other Non-Voted Current Expenditure } \\
\hline Total & B & Exchequer Non Financial Balance & $(A-B)$ \\
\hline \multirow[t]{2}{*}{ Surplus / (Deficit) on Current Account } & $C=(A-B)$ & & \\
\hline & & Exchequer Financing & $\begin{array}{c}(D-E-F)= \\
(A-B)\end{array}$ \\
\hline Receipts and Expenditure - Capital & & Net Acquisition of Financial Assets & $\mathrm{D}$ \\
\hline Receipts & & Net Incurrence of Liabilities & $\mathrm{E}$ \\
\hline Other Capital Receipts & & Change in Exchequer Deposits & $\mathrm{F}$ \\
\hline Total & D & & \\
\hline \multicolumn{4}{|l|}{ Expenditure } \\
\hline \multicolumn{4}{|l|}{ Voted (Departmental Expenditure) } \\
\hline \multicolumn{4}{|l|}{ Non-Voted (Expenditure } \\
\hline Total & E & & \\
\hline Surplus / (Deficit) on Capital Account & $F=(D-E)$ & & \\
\hline Exchequer Surplus / (Deficit) & $\mathrm{C}+\mathrm{F}$ & & \\
\hline Source and Application of Funds & $\mathbf{G}$ & & \\
\hline \multicolumn{4}{|l|}{ Total (Borrowing) / Repayment } \\
\hline \multicolumn{4}{|l|}{ Bonds Issued to Central Bank } \\
\hline \multicolumn{4}{|l|}{$\begin{array}{l}\text { Total Increase / (Decrease) in Exchequer } \\
\text { Deposits and Other Balances }\end{array}$} \\
\hline Exchequer Surplus / (Deficit) & $\mathbf{G}=\mathbf{C + F}$ & & \\
\hline
\end{tabular}


Appendix 1G: Mapping of Exchequer Statement to ESA 95 Classification

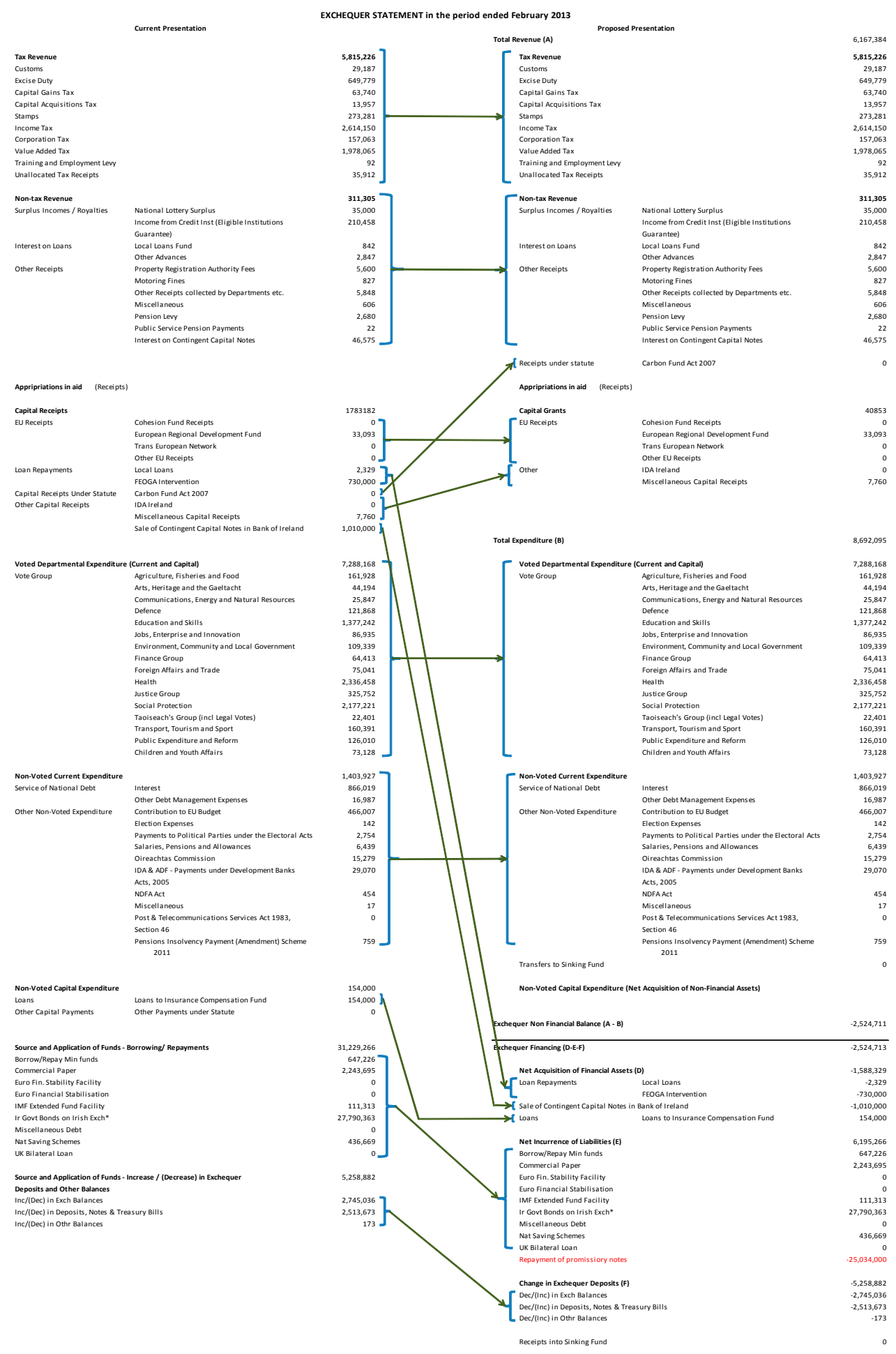


APPENDIX II. COMPLIANCE WITH NEW EU REQUIREMENTS

\begin{tabular}{|c|c|c|c|c|c|c|c|}
\hline Name & Description & $\begin{array}{l}\text { Government Sectors } \\
\text { Identified }\end{array}$ & Variables Reported & $\begin{array}{l}\text { Reference } \\
\text { Period }\end{array}$ & $\begin{array}{l}\text { Estimates } \\
\text { Required } \\
\text { By }\end{array}$ & $\begin{array}{l}\text { Legal } \\
\text { Action } \\
\text { Required }\end{array}$ & $\begin{array}{l}\text { Relevant } \\
\text { Rec }\end{array}$ \\
\hline \multicolumn{8}{|c|}{ Six Pack and Two Pack } \\
\hline $\begin{array}{l}\text { Methodological } \\
\text { reconciliation table } \\
\text { between public } \\
\text { accounts and } \\
\text { ESA95 }\end{array}$ & $\begin{array}{l}\text { Table showing how } \\
\text { the data in the new } \\
\text { monthly and quarterly } \\
\text { fiscal reports can be } \\
\text { related to the main } \\
\text { ESA95 Government } \\
\text { aggregates reported } \\
\text { quarterly }\end{array}$ & $\begin{array}{l}\text { Probably separate } \\
\text { reconciliation table needed } \\
\text { for each sub-sector of } \\
\text { General Government. } \\
\text { Within sub-sectors, units } \\
\text { using the same } \\
\text { accounting/reporting basis } \\
\text { should be grouped } \\
\text { together in separate } \\
\text { tables. }\end{array}$ & $\begin{array}{l}\text { Unclear, but will have to } \\
\text { be presented for } \\
\text { Revenue and } \\
\text { Expenditure }\end{array}$ & $\begin{array}{l}\text { Updated } \\
\text { only if } \\
\text { methodolog } \\
\text { y changes }\end{array}$ & Dec 2013 & $\begin{array}{l}\text { Publish } \\
\text { nationally }\end{array}$ & \\
\hline Monthly fiscal data & $\begin{array}{l}\text { Table showing the } \\
\text { main fiscal } \\
\text { aggregates from } \\
\text { public accounts }\end{array}$ & $\begin{array}{l}\text { Separate tables for (1) } \\
\text { Central Govt, (2) State } \\
\text { Govt and (3) Social } \\
\text { Security Funds. Within } \\
\text { sub-sectors, units using } \\
\text { the same } \\
\text { accounting/reporting basis } \\
\text { should be grouped } \\
\text { together }\end{array}$ & $\begin{array}{l}\text { Total Revenue, Total } \\
\text { Expenditure \& Balance. } \\
\text { Additional breakdowns } \\
\text { recommended but } \\
\text { voluntary }\end{array}$ & Monthly & Jan 2014 & $\begin{array}{l}\text { Publish } \\
\text { nationally }\end{array}$ & $\begin{array}{c}1 . a, 1 b \\
1 c, 4 a\end{array}$ \\
\hline Quarterly fiscal data & $\begin{array}{l}\text { Table showing the } \\
\text { main fiscal } \\
\text { aggregates from } \\
\text { public accounts }\end{array}$ & $\begin{array}{l}\text { Separate tables for (1) } \\
\text { Central Govt, (2) State } \\
\text { Govt, (3) Social Security } \\
\text { Funds \& (4) Local Govt. } \\
\text { Within sub-sectors, units } \\
\text { using the same } \\
\text { accounting/reporting basis } \\
\text { should be grouped } \\
\text { together }\end{array}$ & $\begin{array}{l}\text { Total Revenue, Total } \\
\text { Expenditure \& Balance. } \\
\text { Additional breakdowns } \\
\text { recommended but } \\
\text { voluntary }\end{array}$ & Quarterly & June 2014 & $\begin{array}{l}\text { Publish } \\
\text { nationally }\end{array}$ & 1.a, 1b, 1c \\
\hline $\begin{array}{l}\text { Table of contingent } \\
\text { Government } \\
\text { liabilities }\end{array}$ & Guarantees & $\begin{array}{l}\text { Shown for each sub-sector } \\
\text { of General Government }\end{array}$ & $\begin{array}{l}\text { One-off \& Standardized } \\
\text { guarantees }\end{array}$ & Annual & Oct 2014 & $\begin{array}{l}\text { Publish } \\
\text { nationally }\end{array}$ & 3.d \\
\hline
\end{tabular}




\begin{tabular}{|c|c|c|c|c|c|c|c|}
\hline Name & Description & $\begin{array}{l}\text { Government Sectors } \\
\text { Identified }\end{array}$ & Variables Reported & $\begin{array}{l}\text { Reference } \\
\text { Period }\end{array}$ & $\begin{array}{c}\text { Estimates } \\
\text { Required } \\
\text { By }\end{array}$ & $\begin{array}{c}\text { Legal } \\
\text { Action } \\
\text { Required }\end{array}$ & $\begin{array}{l}\text { Relevant } \\
\text { Rec }\end{array}$ \\
\hline $\begin{array}{l}\text { Table of contingent } \\
\text { Government } \\
\text { liabilities }\end{array}$ & PPPs & $\begin{array}{l}\text { Shown for each sub-sector } \\
\text { of General Government }\end{array}$ & $\begin{array}{l}\text { Adjusted capital value } \\
\text { of off-balance sheet } \\
\text { PPPs }\end{array}$ & Annual & Oct 2014 & $\begin{array}{l}\text { Publish } \\
\text { nationally }\end{array}$ & 2.b, 3.b \\
\hline $\begin{array}{l}\text { Table of contingent } \\
\text { Government } \\
\text { liabilities }\end{array}$ & NPLs & $\begin{array}{l}\text { Shown for each sub-sector } \\
\text { of General Government }\end{array}$ & $\begin{array}{l}\text { Outstanding stock of } \\
\text { non-performing loans }\end{array}$ & Annual & Oct 2014 & $\begin{array}{l}\text { Publish } \\
\text { nationally }\end{array}$ & 3.d \\
\hline $\begin{array}{l}\text { Liabilties of Public } \\
\text { Corporations }\end{array}$ & $\begin{array}{l}\text { Liabilities of individual } \\
\text { companies and not of } \\
\text { the consolidated } \\
\text { Groups. }\end{array}$ & $\begin{array}{l}\text { Shown for each sub-sector } \\
\text { of General Government }\end{array}$ & $\begin{array}{l}\text { Liabilities measured } \\
\text { according to ESA or } \\
\text { business accounting } \\
\text { standards }\end{array}$ & Annual & Dec 2014 & $\begin{array}{l}\text { Publish } \\
\text { nationally }\end{array}$ & 1.d \\
\hline $\begin{array}{l}\text { Participation in } \\
\text { Public Corporations }\end{array}$ & $\begin{array}{l}\text { Government equity in } \\
\text { Public Corporations }\end{array}$ & $\begin{array}{l}\text { Shown for each sub-sector } \\
\text { of General Government }\end{array}$ & $\begin{array}{l}\text { Equity measured at } \\
\text { market or book values }\end{array}$ & Annual & Dec 2014 & $\begin{array}{l}\text { Publish } \\
\text { nationally }\end{array}$ & 1.d \\
\hline
\end{tabular}

European System of Accounts 2010

Reporting requirements under the new ESA are substantially the same as existing arrangements. Some of the Government Accounts Tables currently provided under separate legislation have been subsumed into the new ESA requirements, but the details have not altered much. New requirements under ESA 2010 include

\begin{tabular}{|c|c|c|c|c|c|c|c|}
\hline $\begin{array}{l}\text { Table } 801 \text { (timing } \\
\text { only) }\end{array}$ & $\begin{array}{l}\text { Quarterly non- } \\
\text { financial acounts by } \\
\text { institutional sector }\end{array}$ & General Government & Standard variables & Quarterly & Sept 2014 & $\begin{array}{c}\text { Q2 \& } \\
\text { earlier } \\
\text { submitted } \\
\text { to Eurostat }\end{array}$ & \\
\hline Table 26 & $\begin{array}{l}\text { Nonfinancial assets } \\
\text { by institutional sector }\end{array}$ & General Government & $\begin{array}{l}7 \text { asset categories are } \\
\text { compulsory. Voluntary } \\
\text { reporting of 'Valuables' } \\
\text { and of 'Nonfinancial } \\
\text { non-produced assets.' }\end{array}$ & Annual & Dec 2014 & $\begin{array}{c}\text { Q2 \& } \\
\text { earlier } \\
\text { submitted } \\
\text { to Eurostat }\end{array}$ & $\begin{array}{l}\text { 2.c, 2.d, } \\
\text { 3.c }\end{array}$ \\
\hline
\end{tabular}




\begin{tabular}{|c|c|c|c|c|c|c|c|}
\hline Name & Description & $\begin{array}{c}\text { Government Sectors } \\
\text { Identified }\end{array}$ & Variables Reported & $\begin{array}{l}\text { Reference } \\
\text { Period }\end{array}$ & $\begin{array}{c}\text { Estimates } \\
\text { Required } \\
\text { By }\end{array}$ & $\begin{array}{c}\text { Legal } \\
\text { Action } \\
\text { Required }\end{array}$ & $\begin{array}{l}\text { Relevant } \\
\text { Rec }\end{array}$ \\
\hline Table 29 & $\begin{array}{l}\text { Accrued-to-date } \\
\text { pension entitlements } \\
\text { in social insurance - } \\
\text { three yearly }\end{array}$ & $\begin{array}{l}\text { General Government (\& } \\
\text { others) }\end{array}$ & $\begin{array}{l}\text { Flows \& stocks of } \\
\text { Social Insurance } \\
\text { Schemes including } \\
\text { Government employee } \\
\text { defined benefit } \\
\text { schemes and Social } \\
\text { Security schemes not } \\
\text { currently included in the } \\
\text { standard National } \\
\text { Accounts tables }\end{array}$ & Annual & Dec 2017 & $\begin{array}{l}\text { Year } 2015 \\
\text { submitted } \\
\text { to Eurostat. } \\
\text { Earlier } \\
\text { years's } \\
\text { data } \\
\text { requested } \\
\text { on } \\
\text { voluntary } \\
\text { basis. }\end{array}$ & $2 a, 3 . a$ \\
\hline
\end{tabular}




\section{APPENDIX III. COMPLIANCE WITH IPSAS REQUIREMENTS Areas of Existing or Near Compliance with IPSAS in Ireland}

\begin{tabular}{|c|l|}
\hline IPSAS & \multicolumn{1}{|c|}{ Rationale } \\
\hline IPSAS 1 & $\begin{array}{l}\text { Appropriation Account notes present reconciliation of outturn to expenditure } \\
\text { on accruals basis; (incomplete) balance sheet; cash flow statement. Other } \\
\text { accounts follow FRS or IFRS as appropriate. }\end{array}$ \\
\hline IPSAS 2 & Cash flow statements presented, but exclude cash equivalents. \\
\hline IPSAS 3 & Statements of Accounting Policies provided. \\
\hline IPSAS 12 & Inventories included in balance sheets. \\
\hline IPSAS 13 & Lease information given in accounts following IFRS. \\
\hline IPSAS 17 & $\begin{array}{l}\text { Notes to the balance sheet disclose information about property, plant and } \\
\text { equipment and depreciation. }\end{array}$ \\
\hline IPSAS 18 & Segmental analysis given in notes to the accounts of Public Corporations. \\
\hline IPSAS 19 & $\begin{array}{l}\text { Contingent liability information disclosed. Provisions only in accounts of } \\
\text { Public Corporations. }\end{array}$ \\
\hline IPSAS 20 & Related party disclosures given only in accounts of Public Corporations. \\
\hline IPSAS 24 & Comparison of Estimate and outturn given in Appropriation Accounts. \\
\hline IPSAS 25 & $\begin{array}{l}\text { Pension liabilities or relevant disclosures given only in accounts of Public } \\
\text { Corporations. }\end{array}$ \\
\hline IPSAS 28, 29, 30 & $\begin{array}{l}\text { Financial instruments presented, recognized and measured and appropriate } \\
\text { disclosures given in accounts of Public Corporations following IFRS. }\end{array}$ \\
\hline
\end{tabular}


Linkage Between Recommendations and Adoption of further IPSASs

\begin{tabular}{|c|c|c|}
\hline \multicolumn{2}{|r|}{ Report Recommendation } & \multirow{2}{*}{$\begin{array}{l}\begin{array}{c}\text { Relevant } \\
\text { IPSAS }\end{array} \\
\text { N/A }\end{array}$} \\
\hline $1 \mathrm{a}$ & $\begin{array}{l}\text { Expanding the coverage of the annual budget documentation to present the } \\
\text { gross revenues and expenditures of the consolidated central government }\end{array}$ & \\
\hline $1 \mathrm{~b}$ & $\begin{array}{l}\text { Combining the Finance and Appropriation Accounts into a consolidated } \\
\text { Central Government Financial Statement. }\end{array}$ & $\begin{array}{l}\text { IPSAS } 6 \text { (in } \\
\text { part) }\end{array}$ \\
\hline $1 \mathrm{c}$ & $\begin{array}{l}\text { Providing an overview of the gross revenues and expenditures of central, } \\
\text { local, and general government in budget documentation and in-year fiscal } \\
\text { statistics. }\end{array}$ & $\mathrm{N} / \mathrm{A}$ \\
\hline $1 d$ & Preparing fiscal statistics for the consolidated public sector and its subsectors. & $\mathrm{N} / \mathrm{A}$ \\
\hline $2 a$ & Revaluing and recognizing accrued pension liabilities of public servants. & IPSAS 25 \\
\hline $2 b$ & Recognizing government assets and liabilities associated with PPPs. & IPSAS 32 \\
\hline 2c & $\begin{array}{l}\text { Revaluing and recognizing non-financial assets of central government } \\
\text { departments }\end{array}$ & $\begin{array}{l}\text { IPSAS } 16,17 \\
31\end{array}$ \\
\hline $2 d$ & $\begin{array}{l}\text { Preparing a financial and full balance sheet for the public sector and its } \\
\text { subsectors }\end{array}$ & IPSAS $6,7,8$ \\
\hline $3 a$ & $\begin{array}{l}\text { Reflecting changes in accrued public sector pension liabilities in budget } \\
\text { documentation, statistics, and accounts. }\end{array}$ & IPSAS 25 \\
\hline $3 b$ & $\begin{array}{l}\text { Incorporating information on the annual flow of government investments and } \\
\text { payments under PPPs into fiscal projections, budgets, and accounts }\end{array}$ & IPSAS 32 \\
\hline $3 c$ & $\begin{array}{l}\text { Utilizing department-specific depreciation figures in summary statistics and } \\
\text { accounts. }\end{array}$ & IPSAS 17, 31 \\
\hline $3 d$ & $\begin{array}{l}\text { Recognizing valuation changes in public sector assets, liabilities, and } \\
\text { contingent liabilities in fiscal documentation. }\end{array}$ & $\begin{array}{l}\text { IPSAS 17, 31, } \\
21,26\end{array}$ \\
\hline $3 e$ & $\begin{array}{l}\text { Providing a more comprehensive estimate of revenue foregone from all tax } \\
\text { expenditures }\end{array}$ & IPSAS 23 \\
\hline $4 a$ & $\begin{array}{l}\text { Reorganizing the monthly Exchequer statement to present gross revenues and } \\
\text { expenditures and distinguish non-financial and financial transactions. }\end{array}$ & $\mathrm{N} / \mathrm{A}$ \\
\hline $4 b$ & $\begin{array}{l}\text { Develop an exhaustive program classification which can be mapped to both } \\
\text { individual output/impact indicators and COFOG sectors. }\end{array}$ & $\begin{array}{l}\text { IPSAS } 18 \text { (in } \\
\text { part) }\end{array}$ \\
\hline $4 c$ & Develop a harmonized chart of accounts for all public sector entities. & $\mathrm{N} / \mathrm{A}$ \\
\hline 5 & $\begin{array}{l}\text { Accelerate the production, presentation, and approval of the annual budget } \\
\text { and accounts }\end{array}$ & $\mathrm{N} / \mathrm{A}$ \\
\hline 6 & $\begin{array}{l}\text { Regularly publish long-term fiscal projections as part of the annual budget } \\
\text { documentation. }\end{array}$ & \\
\hline 7 & $\begin{array}{l}\text { Provide a more comprehensive reconciliation of changes to key fiscal } \\
\text { aggregates between successive fiscal forecasts }\end{array}$ & \\
\hline 8 & $\begin{array}{l}\text { The Department of Finance should publish as part of budget documentation a } \\
\text { comprehensive statement of fiscal risks }\end{array}$ & $\begin{array}{l}\text { IPSAS } 30 \text { (in } \\
\text { part) }\end{array}$ \\
\hline 9 & $\begin{array}{l}\text { The Department of Finance or NTMA should publish, at least once a year, a } \\
\text { report on the government's strategy for the management of its portfolio of } \\
\text { assets and liabilities, including debt, the NPRF fund, and shares in financial } \\
\text { and nonfinancial corporations. }\end{array}$ & $\begin{array}{l}\text { IPSAS } 30 \text { (in } \\
\text { part) }\end{array}$ \\
\hline 10 & $\begin{array}{l}\text { Establish a permanent government financial reporting unit in the DoF or DPER } \\
\text { headed by a Chief Financial Officer or Accountant General. }\end{array}$ & \\
\hline
\end{tabular}




\section{Complying with Remaining IPSASs for Individual Entities}

In general, a requirement to follow FRS 100, 101 and 102 in the short term will ensure that government entities (both central and local) will adopt an accounting framework that will facilitate a move to IPSAS in the medium to long term. The table below sets out the steps that might be taken to address some of the common gaps identified in an initial analysis of central and local government accounts.

\begin{tabular}{|c|c|}
\hline IPSAS & Additional Steps Required \\
\hline IPSAS 1 & $\begin{array}{l}\text { The existing notes to the accounts should be expanded to include better analysis of } \\
\text { receivables (but see note against IPSAS 9) and payables. The information should be } \\
\text { readily to hand. }\end{array}$ \\
\hline IPSAS 9 & $\begin{array}{l}\text { Gap analysis for central government showed that most income is accounted for on a } \\
\text { cash basis. Types of Appropriations in Aid and other receipts (in semi-state entities) } \\
\text { should be reviewed and appropriate income recognition points identified in order that } \\
\text { receivables can be accounted for. Income should be stated net of any provision for bad } \\
\text { or doubtful debts. }\end{array}$ \\
\hline IPSAS 13 & $\begin{array}{l}\text { Those entities holding property, plant and equipment under rental agreements should } \\
\text { determine whether material leases are operating or finance leases. Any finance leases } \\
\text { should be capitalised and included in the fixed assets note. }\end{array}$ \\
\hline IPSAS 16 & $\begin{array}{l}\text { Government entities (particularly semi-state entities, local government and public } \\
\text { corporations) should determine whether they hold any properties for the purposes of } \\
\text { either earning rental income or for capital appreciation and account for them as } \\
\text { investment properties. }\end{array}$ \\
\hline IPSAS 17 & $\begin{array}{l}\text { The IMF recommends that property, plant and equipment be held at valuation. As a first } \\
\text { step, entities should revalue land and buildings and any other significant assets to } \\
\text { current values. This will require additional resource from the Valuation Office. }\end{array}$ \\
\hline IPSAS 19 & $\begin{array}{l}\text { All entities should determine whether their activities or operations give rise to events } \\
\text { that should be recognized as a provision or disclosed as a contingent liability (for } \\
\text { example, outstanding legal claims/actions). Any such provision or contingent liability } \\
\text { should be reported in the accounts of the entity which is the ultimate settler of the claim. }\end{array}$ \\
\hline $\begin{array}{l}\text { IPSAS } 21 \\
\text { and } 26\end{array}$ & $\begin{array}{l}\text { As a result of carrying land and building at valuation, impairment reviews will need to be } \\
\text { carried out annually. This will also have resource implications for the Valuation Office. }\end{array}$ \\
\hline IPSAS 25 & $\begin{array}{l}\text { All entities should make appropriate disclosures about their pension arrangements. For } \\
\text { entities whose employees are members of a central scheme where liabilities cannot be } \\
\text { allocated to the employing entities, disclosures will be limited. Where an entity's } \\
\text { employees are members of a scheme where the liabilities can be allocated, the entity } \\
\text { will account for the liability. The only offset to the liability will be the fair value of any } \\
\text { pension plan assets (an unfunded scheme has no assets). } \\
\text { Accounting for pension schemes is complex. Each centralized pension scheme (for } \\
\text { example, the plan inferred by the Superannuation and Retired Allowances Vote) should } \\
\text { produce its own pension fund account following the requirements set out in FRS } 102 \text {. }\end{array}$ \\
\hline $\begin{array}{l}\text { IPSAS 28, } \\
\quad 29,30\end{array}$ & $\begin{array}{l}\text { In addition to the reports on fiscal risks and the management of assets and liabilities } \\
\text { (recommendations } 8 \text { and 9), government entities should review whether they hold } \\
\text { financial instruments and recognize appropriately, providing the required disclosures. }\end{array}$ \\
\hline
\end{tabular}




\section{APPENDIX IV. POSSIBLE OUTLINE OF A STATEMENT OF FISCAL RISKS}

\begin{tabular}{|c|c|}
\hline Section & Sources \\
\hline $\begin{array}{l}\text { I. Macroeconomic Analysis } \\
\text { Discussion of macroeconomic outlook } \\
\text { Description of historical differences between forecasts and } \\
\text { outcomes } \\
\text { Analysis of sensitivity of forecasts to key parameters } \\
\text { Scenario analysis and, ultimately, stochastic analysis } \\
\text { Government's strategy for mitigating the risks to the extent } \\
\text { possible }\end{array}$ & $\begin{array}{c}\text { Medium-Term Fiscal Statement } \\
\text { Economic and Fiscal Outlook } \\
\text { Stability Programme Update } \\
\text { IFAC's Reports }\end{array}$ \\
\hline $\begin{array}{l}\text { II. Exposure to the Financial Sector } \\
\text { Potential fiscal risks associated with fragility of the financial } \\
\text { sector } \\
\text { Explicit contingent liabilities related to financial sector } \\
\text { Government's strategy for mitigating the risk }\end{array}$ & $\begin{array}{l}\text { DoF presesentations } \\
\text { CBI Macro-Financial Review } \\
\text { Finance Accounts } \\
\text { C\&G Report }\end{array}$ \\
\hline $\begin{array}{l}\text { III. Other Contingent Liabilities } \\
\text { Guarantees other than for financial sector } \\
\text { Litigation } \\
\text { Callable capital } \\
\text { Minimum-revenue guarantees for toll roads } \\
\text { Government's strategy for mitigating risks where possible }\end{array}$ & $\begin{array}{c}\text { Finance Accounts } \\
\text { Appropriation Accounts } \\
\text { Appropriation Accounts }\end{array}$ \\
\hline $\begin{array}{l}\text { IV. Specific Revenue Risks } \\
\text { Any risks to revenue other than those incorporated in } \\
\text { macroeconomic analysis (e.g., the pharmaceutical "patent cliff") } \\
\text { Government's strategy for mitigating risks where possible }\end{array}$ & $\begin{array}{l}\text { Medium-Term Fiscal Statement } \\
\text { Economic and Fiscal Outlook }\end{array}$ \\
\hline $\begin{array}{l}\text { V. Assets and Liabilities } \\
\text { Risks related to values of and cash flows associated with the } \\
\text { government's assets and liabilities, considered as a portfolio: } \\
\text { NTMA debt } \\
\text { NPRF assets } \\
\text { Derivatives } \\
\text { Shares in banks (if not discussed above) } \\
\text { Shares in nonfinancial enterprises } \\
\text { Public-service pension liabilities } \\
\text { PPP assets and liabilities } \\
\text { Government's strategy for managing portfolio and mitigating } \\
\text { risks }\end{array}$ & $\begin{array}{l}\text { NTMA Annual Report } \\
\text { NPRF Annual Report } \\
\text { NewERA reports if any } \\
\text { C\&AG's report }\end{array}$ \\
\hline
\end{tabular}

